\title{
Articles
}

\section{Markets, Democracy, and Ethnicity: Toward a New Paradigm for Law and Development}

\author{
Amy L. Chua ${ }^{\dagger}$
}

\section{CONTENTS}

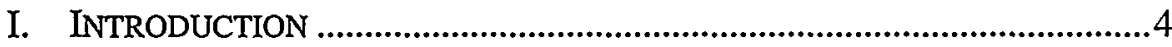

II. LAW AND DEVELOPMENT: THE CURRENT PARADIGM .............................. 8

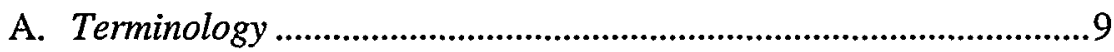

B. The Early Law and Development Movement ...................................11

C. Law and Development Today ............................................................13

1. The Current Literature ...........................................................14

2. Policy and Practice...............................................................17

D. The Problem in the Current Paradigm ............................................19

III. UNDERDEVELOPMENT AND OVERACHIEVEMENT ...................................21

A. Ethnoeconomics in the Developing World .......................................21

B. Ethnoeconomics in the Developed World ..........................................27

C. Economic Dominance and Market Dominance................................29

$\dagger$ Associate Professor, Duke University School of Law. I would like to thank Bruce Ackerman, Aslı Bâli, Kate Bartlett, Lan Cao, Walter Dellinger, Tatiana Doran, Hermann Giliomee, Henry Hansmann, Donald Horowitz, Benedict Kingsbury, Askar Moukhitdinov, Jonathan Ocko, Jeff Powell, Susan Rose-Ackerman, Ed Rubin, Chris Schroeder, Laura Underkuffler-Freund, Andre van der Walt, Johan van der Walt, and the participants in faculty workshops at American University, Boston University, University of Capetown, Duke University, University of Michigan, University of Toronto, and Rand Afrikaans University. I am especially grateful to Jed Rubenfeld. Outstanding research assistance was provided by Julie Bentley, Mark Bernstein, Janeen Denson, Melanie Dunshee, Wes Lovy, Kevin Marr, Tim McCarthy, Amanda McMillian, Mike Minor, John O'Leary, Brian Rohal, Janet Sinder, Cathy Surles, Bethany Thomas, and Katherine Topulos. 
IV. MARKETIZATION, DEMOCRATIZATION, AND ETHNONATIONALISM:

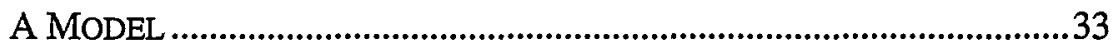

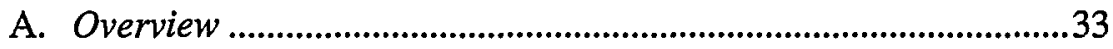

B. Definition and Prevalence of Model Conditions ...............................35

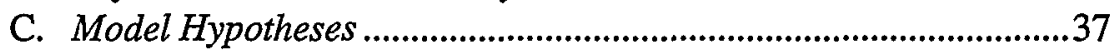

1. Hypothesis I: Ethnoeconomic Resentment Against MarketDominant Minorities....................................................................37

2. Hypothesis II: Ethnonationalism and Democratization ...........42

3. Hypothesis III: Model Outcomes .................................................47

a. Antimarket Backlash ........................................................48

b. Eliminationist or Final "Solutions" ................................51

c. Retreat from Democracy ......................................................54

D. Potential Exceptions and Complications ........................................57

1. Possible Negative Cases..................................................57

a. Thailand ……......................................................................57

b. The Philippines......................................................................59

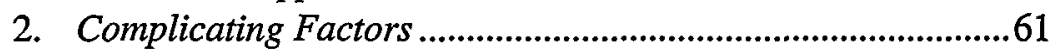

E. General Policy Implications of the Model .......................................62

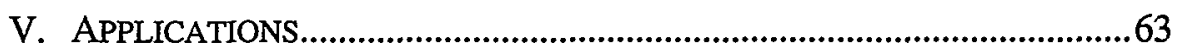

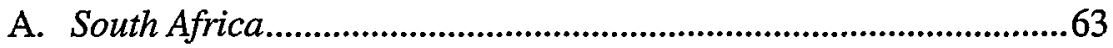

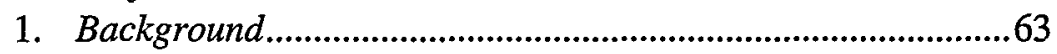

2. Satisfaction of Model Conditions............................................65

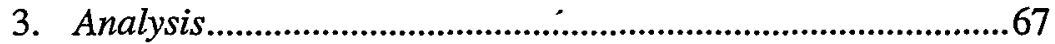

a. Antiwhite, Antimarket Backlash .......................................68

b. Eliminationist Strategies ......................................................72

c. Antidemocracy Backlash .......................................................74

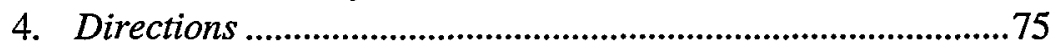

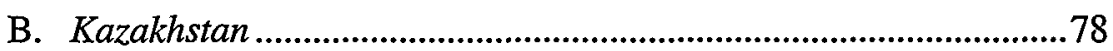

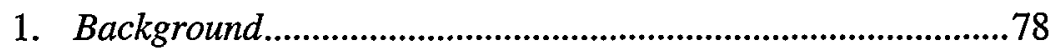

2. Satisfaction of Model Conditions................................................8 83

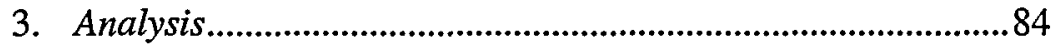

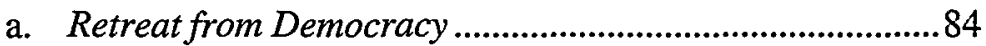

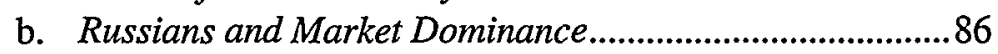

c. Anti-Russian, Antimarket Backlash?.................................8

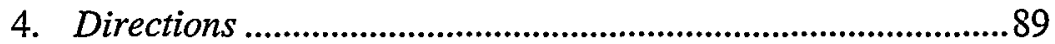

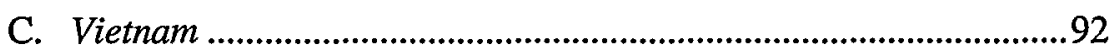

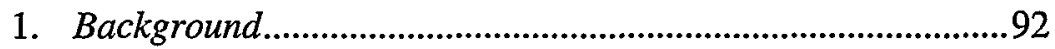

2. Satisfaction of Model Conditions..........................................97

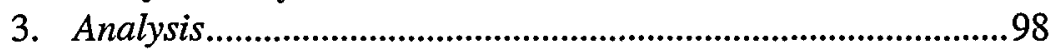

a. The Significance of the Vietnamese Chinese .......................98 
b. Political Favoritism, Corruption, and the Question of Market Dominance ............................................................101

c. The Possibility of Vietnamese Exceptionalism..................102

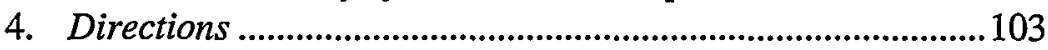

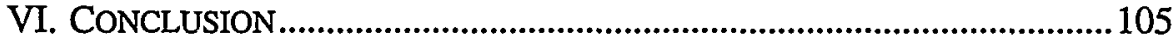




\section{INTRODUCTION}

It is by now a commonplace that we are living in a period of radical global transformation. ' Particularly in the developing world, this transformation has had two watchwords: markets and democracy. ${ }^{2}$ Indeed, the reascendant teleology of free-market democracy has redefined the very concept of underdevelopment-a term that has shed its exclusively Third World trappings and today joins in a single embrace countries from Algeria to Azerbaijan, from Pakistan to Poland. ${ }^{3}$

Marketization and democratization each have been the site of massive Western legal intervention in the developing world. Legal work on marketization ranges from structuring international project finance ${ }^{4}$ to drafting market-oriented laws ${ }^{5}$ to developing legal regimes that facilitate the transition from command to market economies. ${ }^{6}$ Work on democratization includes not only writing constitutions ${ }^{7}$ but also grappling with formidable

1. See, e.g., GEORGE SOROS, UNDERWRITING DEMOCRACY at $\mathrm{x}(1990)$ (noting the "radical transformation" of the international political landscape); Bruce Ackerman, The Rise of World Constitutionalism, 83 VA. L. REV. 771, 774 (1997) (decrying the indifference of American constitutional thought to "world-historical transformation"); George E. Condon, Jr., Pope Urges U.S. Not To Shut Door to Immigrants, SAN DIEGo UnION-TRIB., Oct. 5, 1995, at A1 (quoting Pope John Paul II describing the "profound transformation" of the international system); Jim Hoagland, Bibi's Choice, WASH. POST, June 6, 1996, at A29 (referring to a "dizzying global transformation").

2. See, e.g., JOSEPH E. STIGLITZ, WhITHER SOCIALISM? 1-3 (1995); LeSter C. THUROW, THE FUTURE OF CAPITALISM 1-5 (1996); ROBERTO MANGABEIRA UNGER, DEMOCRACY REALIZED (forthcoming Oct. 1998) (manuscript at 5, on file with The Yale Law Journal); THE WORLD BANK GROUP, LEARNING FROM THE PAST, EMBRACING THE FUTURE 10-13 (1994); Samuel P. Huntington, Challenges Facing Democracy: What Cost Freedom?, CURRENT, June 1993, at 22, 22.

3. See, e.g., STEPHAN HaGgard \& ROBERT R. KaUfMan, THe Polmical ECONOMY OF DEMOCRATIC TRANSITIONS 3, 15-17 (1995); Claus Offe, Cultural Aspects of Consolidation: A Note on the Peculiarities of Postcommunist Transformations, E. EUR. CONST. REV., Fall 1997, at 64, 64-65 (1997); cf. Michael Mann, Nation-States in Europe and Other Continents: Diversifying, Developing, Not Dying, DaEDALus, Summer 1993, at 115, 136 (describing the multitude of "semieffective states" that are "coping with uneven modernity-unevenly developed or enclave capitalisms [and] bulging state administrations sponsoring development and dispensing corruption").

4. See, e.g., John E. Morris, Project Finance: New Telecom and Oil and Gas Deals, Plus Newly Opened Economies in the Developing World, Brought a Surge of Project Financings, AM. LAw., Apr. 1997, at 23, 24, 27; Jones Day Poaches Skadden Arps Project Finance Lawyer, LAWYER, Feb. 11, 1997, at 5.

5. See, e.g., Linda Himelstein, Big Oil Plays a Big Role Shaping Russia's Energy Laws, LEGAL TMMES, Jan. 13, 1992, at 1; Ken Myers, East-West Scholar Cooperation Becoming a Booming Business, NAT'L L.J., Oct. 5, 1992, at 4; Tina Rosenberg, In Albania, Justice Is Now at Least a Possibility: Building Law in the Nation That Defined Communist Lawlessness, LEGAL TIMES, Jan. 2, 1995, at 1.

6. See, e.g., ABA CENT. \& E. EUR. LAW INITIATIVE (CEELI), ANALYSIS OF THE DRAFT LAW ON FOREIGN INVESTMENT ACTIVITIES IN NIZHNY NOVGOROD OBLAST (1996) [hereinafter ANALYSIS OF NIZHNY NOVGOROD INVESTMENT LAW]; see also infra text accompanying notes 38-39.

7. See, e.g., RETT R. LUDWIKOWSKI, CONSTITUTION-MAKING IN THE REGION OF FORMER SOVIET DOMINANCE 1-3 (1996); Jon Elster, The Role of Institutional Interest in East European 
issues such as the transplantability of Western social and political institutions ${ }^{8}$ and postcommunist state building.'

But there is one constitutive element of developing societies that these interventions repeatedly overlook. Entrenched ethnic divisions permeate most developing countries, ${ }^{10}$ and these divisions bear a distinctive and potentially subversive relationship to the project of marketization and democratization. In First World countries, markets have tended to reinforce the economic dominance of a perceived ethnic majority over those countries' most salient ethnic minorities-hence the controversial calls for (and backlash against) market-"correcting" affirmative action for blacks and Hispanics in the United States. ${ }^{11}$ In the developing world, the ethnoeconomic dynamic tends to be just the reverse: Markets often reinforce the economic dominance of certain ethnic minorities. In the First World, democracy poses no radical challenge to economically dominant ethnic groups. ${ }^{12}$ By contrast, in the developing world, democracy characteristically pits a politically powerful but impoverished "indigenous" majority ${ }^{13}$ against an economically dominant ethnic minority.

Constitution-Making, E. EUR. CONST. REV., Winter 1996, at 63, 63; Stephen Kanter, Constitution Making in Kazakhstan, 5 INT'L LEGAL PERSP. 65 (1993).

8. See infra notes 64-69 and accompanying text.

9. See, e.g., Susan Rose-Ackerman, Reducing Bribery in the Public Sector, in CORRUPTION AND DEMOCRACY 21, 22 (Duc V. Trang ed., 1994) (noting that corruption, itself often a response to a weak state, may in tum render more difficult "the move to a modern bureaucratic, democratic state"); Stephen Holmes, Can Weak-State Liberalism Survive? 3-7 (Spring 1997) (unpublished manuscript, on file with The Yale Law Journal) (discussing the problems hindering the establishment of a liberal state in postcommunist Russia).

10. See, e.g., DONALD L. HOROWITZ, ETHNIC GROUPS IN CONFLICT 3-4, 6 (1985); ANTHONY D. SMITH, THE ETHNIC REVIVAL 8-12 (1981).

11. See, e.g., William Claiborne, Affirmative Action Ban Is Upheld: California Proposition Constitutionally Valid, U.S. Appeals Panel Says, WASH. POST, Apr. 9, 1997, at A1; Anne Laurent, The Great Divide: Fear, Anger and Resentment in the Federal Diversity Crusade, NAT'L J., Apr. 1996, at 12. There is obvious artificiality in referring to "whites" as an ethnic group in a country such as the United States (note, for example, that Italian Americans are counted as "whites" whereas Hispanic Americans are generally treated as a separate ethnic group). See BUREAU OF THE CENSUS, U.S. DEP'T OF COMMERCE, 1990 CPH-2-1, 1990 CENSUS OF POPUlation AND HousIng: POPULATION AND HOUSING UNIT COUNTS, UNITED STATES app. E6 (1990) (requesting information regarding the respondent's "race" in question 4 and asking whether the respondent is "of Spanish/Hispanic origin" in question 7); see also IAN F. HANEY LOPEZ, WHITE BY LAW: THE LEGAL CONSTRUCTION OF RACE at xiv (1996) (noting that "White" refers to an "unstable category which gains its meaning only through social relations and that encompasses a profoundly diverse set of persons"). Nonetheless, it remains the case that the core ethnic problem in countries such as the United States is one that pits an economically and politically dominant white majority against economically and politically weaker ethnic minorities.

12. See infra note 132. This might change in the future. For example, according to some demographers (and opponents of immigration), whites could become a minority in the United States as early as 2050 if percentages of Hispanic, Asian, and African Americans continue to rise. See Tom Morganthau, The Face of the Future, NEwSWEEK, Jan. 27, 1997, at 58.

13. As explained below, claims of majority "indigenousness" are often extremely artificial. See infra text accompanying notes 167-172. 
From these simple premises, a number of profound implications follow. First, far from having the civilizing effect that Montesquieu envisioned, ${ }^{14}$ marketization in the developing world is often destabilizing, fomenting ethnic envy and hatred among often chronically poor majorities. Second, in most developing countries, democracy can proceed only in deep tension with markets. Rather than reinforcing the market's efficiency and wealthproducing effects, democratization ordinarily will lead to powerful ethnonationalist, antimarket pressures. Third, ethnic division in the developing world cannot be regarded as just another aspect of underdevelopment curable by the universal prescription of free-market democracy. On the contrary, the combined pursuit of marketization and democratization in the developing world is likely to catalyze ethnic tensions, with potentially catastrophic effects, including the subversion of both markets and democracy.

Despite compelling historical and sociological evidence corroborating these propositions, ${ }^{15}$ and despite the unprecedented influence currently wielded by American lawyers in the developing world, ${ }^{16}$ the interrelationship among marketization, democratization, and ethnic conflict has been almost entirely ignored. ${ }^{17}$ This Article will provide a framework for analyzing and addressing the consequences likely to ensue when markets and democracy collide with the particular ethnic structures that characterize most developing societies. ${ }^{18}$ Although there are other potential axes of social division in developing societies, over the last several decades

14. See Charles L. MONTESQuiEu, ThE SPIRIT of THE LAWs 338 (Anne M. Cohler et al. eds. \& trans., 1989) (1748); see also Carol M. Rose, Property as the Keystone Right?, 71 NoTRE DAME L. REV. 329, 352 (1996) (discussing 18th-century economic thinkers who saw commerce as "softening and civilizing rough manners").

15. See, e.g., infra notes 178-200, 212-241, 252-272, 301-307 and accompanying text.

16. See infra note 51 .

17. There is a large theoretical and empirical literature on the correlation between ethnic fragmentation and economic growth. See, e.g., William Easterly \& Ross Levine, Africa's Growth Tragedy: Policies and Ethnic Divisions, 112 Q.J. ECON. 1203 (1997); Ted Robert Gur, Peoples Against States: Ethnopolitical Conflict and the Changing World System, 38 INT'L STUD. Q. 347 (1994). There is also a significant literature studying the link between markets and democracy. See, e.g., CAPITALISM, SOCIALISM, AND DEMOCRACY REVISITED (Larry Diamond \& Marc F. Plattner eds., 1993); HAGGARD \& KAUFMAN, supra note 3; Jose María Maravall, The Myth of the Authoritarian Advantage, J. DEMOCRACY, Oct. 1994, at 17; Minxin Pei, The Puzzle of the East Asian Exceptionalism, J. DEMOCRACY, Oct. 1994, at 90. In addition, a growing literature explores the relationship between democracy and ethnic conflict. See sources cited infra note 208. To date, however, no one has systematically analyzed the interrelationship among all three forces.

18. In an earlier article, I analyzed the relationship in Latin America and Southeast Asia between markets and ethnicity. See Amy L. Chua, The Privatization-Nationalization Cycle: The Link Between Markets and Ethnicity in Developing Countries, 95 COLUM. L. REV. 223 (1995). This Article expands my earlier inquiry by adding democratization to the picture and by broadening my geographical focus. Under the model proposed in this Article, nationalization is just one of several possible equilibria that may result when markets and democracy are pursued in the face of entrenched ethnic divisions. See infra text accompanying notes 248-262. 
ethnicity "[a]s a political idea, as a mobilizing principle," ${ }^{19}$ has spread through the world with striking new intensity ${ }^{20}$ and has been a far more fertile source of mass conflict than, for example, class or religion. ${ }^{21}$

Part II describes the prevailing law and development paradigm and argues that the ideology of free-market democracy forms the theoretical core of today's international development literature, policy, and practice. Part III highlights a fundamental and pervasive feature of developing societies that lawyers and legal scholars involved in the developing world almost uniformly have disregarded. Most developing countries have one or more ethnic minorities who, for widely varying reasons, have economically dominated the "indigenous" majorities around them. Under certain conditions, the presence of an economically dominant minority will introduce a fundamental tension between markets and democracy. This will be the case whenever the economically dominant minority is also marketdominant, meaning that it tends to be economically dominant under market conditions. ${ }^{22}$ In developing countries with a market-dominant minority, markets and democracy will tend to favor different ethnic groups. Markets will (by definition) benefit the market-dominant minority, while democracy will increase the power of the relatively impoverished majority. In these circumstances, markets and democracy will not be mutually reinforcing. Rather, the combined pursuit of markets and democracy will produce a very charged and unstable situation.

Part IV proposes a model to explore the consequences of pursuing markets and democracy under these conditions. The sobering thrust of the model is that in many developing countries, the combined pursuit of marketization and democratization will likely lead to one of three nonexclusive outcomes: (1) an ethnically fueled antimarket backlash; (2) actions directed at eliminating the market-dominant minority (for example, atrocity or expulsion); or (3) a retreat from democracy.

Part V applies the model developed in Part IV to three countries currently receiving extraordinary attention from the international business and legal communities: South Africa (the "next Hong Kong?" 23), Kazakhstan (the next Kuwait? $?^{24}$ ), and Vietnam (the next "Asian Tiger?" ${ }^{25}$ ).

19. Nathan Glazer \& Daniel P. Moynihan, Introduction to ETHNICITY: THEORY AND EXPERIENCE 20 (Nathan Glazer \& Daniel P. Moynihan eds., 1975).

20. See id. at $5-6,20,25$.

21. See infra notes $158-159$ and accompanying text.

22. Whether any given ethnic minority is market-dominant is a complex question that I discuss more fully below. See infra Section III.C.

23. James M. Pethokoukis, Investor's Corner: Will South Africa Be the Next Hong Kong?, INVESTOR's BUS. DAILY, May 27, 1994, at A1.

24. Cf. Helen Davidson, Kazakhstan, SUNDAY TmEs (London), Apr. 16, 1995 (noting that Kazakhstan's oil reserves rival those of Kuwait), available in LEXIS, News Library, NON-US File. 
Without purporting to offer a how-to guide, Part $\mathrm{V}$ explores the question of which reforms, legal and nonlegal, would lead to the long-term success of markets and democracy in the developing world. If the model is correct, a critical policy question is whether the potentially explosive ethnic dynamics triggered by markets and democracy in developing countries can be kept in check with conventional human rights and social welfare measures (for example, judicial reform, international treaties, progressive taxation, social security, and public works projects) or whether they require more radical measures. Ultimately, the historical record of the developing world suggests that, short-term efficiency costs notwithstanding, narrowly tailored, ethnically conscious interventions into the market may prove the best way of forestalling more drastic outcomes (for example, ethnically targeted expropriations or ethnic eliminationism). Along with market adjustments, there might also be room for ethnically conscious adjustments to the democratic process.

In their systematic ahistoricism, Western lawyers involved in the developing world have not focused enough on whether today's sophisticated market initiatives fundamentally differ from the market policies of the past when viewed from a distributional and ethnodistributional perspective. Are today's international asset securitizations and telecommunications privatizations structurally any more advantageous to majorities in developing countries than yesterday's mining concessions? Why have some groups repeatedly fared better than others under market conditions? Proponents of marketization and democratization must start confronting these questions, however awkward or unsettling. If they do not, markets and democracy in the developing world will remain mutually subversive.

\section{LAW AND DEVELOPMENT: THE CURRENT PARADIGM}

Notwithstanding the operatic "death" of the law and development movement twenty years ago, its central tenets remain the intellectual backbone of international development policy and practice. Section A will clarify my use of certain terminology in this Article. Section B will describe the rise and fall of the early law and development movement. Section $C$ will describe the prevailing law and development orthodoxy, as manifested both in the current literature and in practical international application. Finally, Section $\mathrm{D}$ will highlight a fundamental problem in the current paradigm.

25. K.P. Waran, Vietnam Can Become an 'Asian Tiger,' Says PM, NEW STRAITS TIMES, Mar. 8,1996 , at 1 . 


\section{A. Terminology}

In this Article, the term "marketization" refers to the whole spectrum of efforts toward privatization and contractualization of economic activity in developing and transitional economies, ranging from the replacement of a command economy with market mechanisms to typical "economic liberalization" measures (such as privatization, liberalization of investment and trade restrictions, and elimination of price controls) ${ }^{26}$

"Democracy" is a contested term and can take numerous forms. ${ }^{27}$ In this Article, I will adopt what Jon Elster describes as the basic definition of democracy: "simple majority rule, based on the principle 'One person one vote." 28 The term "democratization" will refer broadly to any political

26. Cf. LUDWIKowSKI, supra note 7 , at 163 (defining marketization as a "fundamental structural economic change signified by massive privatization, price liberalization, the introduction of internal exchange convertibility, a certain amount of competition, and elimination of most governmental subsidies"). Although virtually all economic systems have both market and nonmarket elements, the extent of govemment economic intervention in any given society will be a matter of degree, ranging "from the all-encompassing role assumed in some centrally planned socialist economies, to the very limited role that it [has heretofore undertaken] in Hong Kong." STIGLITZ, supra note 2, at 231. It is thus possible to speak of relatively more or less "marketized" economies.

27. In Joseph Schumpeter's classic formulation, democracy is "that institutional arrangement for arriving at political decisions in which individuals acquire the power to decide by means of a competitive struggle for the people's vote." JOSEPH A. SCHUMPETER, CAPITALISM, SOCIALISM, AND DEMOCRACY 269 (3d ed. 1950). Many have found Schumpeter's "procedural" approach problematic. See, e.g., Philippe C. Schmitter \& Terry Lynn Karl, What Democracy Is . . and Is Not, in TRANSTIIONS TO DEMOCRACY: COMPARATIVE PERSPECTIVES FROM SOUTHERN EUROPE, LATIN AMERICA AND EASTERN EUROPE 3, 15 n.3 (Geoffrey Pridham ed., 1995) [hereinafter TRANSITIONS TO DEMOCRACY]. For an important recent contribution building on (but also critiquing in part) the Schumpeterian tradition, see ROBERT A. DAHL, DEMOCRACY AND ITS Critics 121-22, 220-22 (1989). See also CARLos SANTIAGo Nino, THE Constitution of DELIBERATIVE DEMOCRACY (1996) (deliberative model); WILlIAM H. RIKER, LIBERALISM AGAINST POPULISM (1982) (rational choice approach); MICHAEL. J. SANDEL, DEMOCRACY'S DISCONTENT (1996) (communitarian perspective).

28. Jon Elster, Introduction to CONSTITUTIONALISM AND DEMOCRACY 1 (Jon Elster \& Rune Slagstad eds., 1988). Samuel Huntington has summarized the issue nicely:

[T] people democracy has or should have much more sweeping and idealistic connotations. To them, "true democracy" means liberté, égalité, fratermité, effective citizen control over policy.... and various other civic virtues.... [Defining] democracy in these terms ... raises all the problems that come up with the definitions of democracy by source or by purpose. Fuzzy norms do not yield useful analysis. Elections, open, free, and fair, are the essence of democracy, the inescapable sine qua non.

Samuel P. Huntington, The ThiRd Wave: Democratization IN the Late Twentieth CENTURY 9 (1991); cf. Mancur Olson, Dictatorship, Democracy, and Development, 87 AM. POL. SCI. REV. 567, 570 (1993) (noting that while "[d]emocracies vary so much that no one conclusion can cover all cases .... many practical insights can be obtained by thinking first about one of the simplest democratic situations"). 
reform introducing greater electoral competition ${ }^{29}$ or increased majoritarianism in the political process. ${ }^{30}$

Ethnicity is another controversial concept that has generated much debate among social scientists. ${ }^{31}$ Following Horowitz and others, I adopt "an inclusive conception of ethnicity," ${ }^{32}$ which acknowledges the importance of subjective perceptions of identity ${ }^{33}$ and encompasses differences along racial lines (for example, blacks and whites in the United States or South Africa), lines of geographic origin (for example, Malays, Chinese, and Indians in Malaysia), and linguistic, religious, tribal, or other cultural lines (for example, Protestants and Catholics in Ireland, and Hutus and Tutsis in Rwanda). ${ }^{34}$

I use terms such as "developing" and "underdeveloped" to refer to countries with, relatively speaking, low per capita incomes, low rates of labor productivity, and large segments of their populations engaged in

29. See SCHUMPETER, supra note 27 , at 269.

30. See, e.g., Ann Seidman \& Robert B. Seidman, Beyond Contested Elections: The Processes of Bill Creation and the Fulfillment of Democracy's Promises to the Third World, 34 HARV. J. ON LEGIS. 1 (1997) (advocating a definition of democracy in terms of increased majority input and decisionmaking rather than mere electoral competition).

31. A principal debate in this area has been between "primordialism" and "instrumentalism." Primordialism holds that ethnic identity is "so deeply rooted" (perhaps even biologically) "in historical experience that it should properly be treated as a given in human relations." MULTON J. ESMAN, ETHNIC POLITICS 10 (1994). For scholarship inclining toward or embracing primordialism, see HAROLD R. ISAACS, IDOLS OF THE TRIBE: GROUP IDENTITY AND POLITICAL ChANGE 38-45 (1975); ANTHONY D. SMITH, THE ETHNIC ORIGINS OF NATIONS 1113, 32 (1986); and PIERre L. VAN DEN BERGHe, The Ethnic Phenomenon 27-28, 35-36 (1981). By contrast, instrumentalists emphasize the importance of subjective factors and hold "that ethnicity is not a historical given at all, but in fact a highly adaptive and malleable phenomenon." ESMAN, supra, at 10. "Thus, according to many instrumentalists, ethnicity is either an ideology that elites construct and deconstruct for opportunistic reasons or a set of myths calculated to mobilize mass support." Id. at 11. For expressions of the instrumentalist position, see PAUL R. BRASS, ETHNICITY AND NATIONALISM: THEORY AND COMPARISON 19 (1991); Fredrik Barth, Introduction to ETHNIC GROUPS AND BOUNDARIES 9-10, 13-15 (Fredrik Barth ed., 1969); and sources cited infra note 177 .

32. HoRowTZ, supra note 10, at 41.

33. See id. at 52-53; see also ESMAN, supra note 31, at 14 (stating that " [t]he polar extremes of primordial givens and of instrumental opportunism seldom account for the real behavior of ethnic communities"); Timothy M. Frye, Ethnicity, Sovereignty and Transitions from NonDemocratic Rule, 45 J. INT'L AFF. 599, 602 (1992) (defining ethnicity as a "subjectively held sense of shared identity based on objective cultural or regional criteria").

34. See Albert O. HIRSCHMAN, Introduction: Political Economics and Possibilism, in A BIAS FOR HOPE: ESSAYS ON DEVELOPMENT AND LATIN AMERICA 1, 14 (1971); HoROWITZ, supra note 10 , at 41 . Horowitz and others have suggested that ethnicity is best understood "as a form of greatly extended kinship":

The whole matter has been put nicely by Joshua A. Fishman. Kinship, he says, "is the basis of one's felt bond to one's own kind .... It is the basis of one's dependency, sociability and intimacy with them as a matter of course." And, concludes Fishman, "ethnicity may be the maximal case of societally organized intimacy and kinship experience." The ethnic tie is simultaneously suffused with overtones of familial duty and laden with depths of familial emotion.

HOROWITZ, supra note 10, at 59-60 (footnote omitted). 
agriculture. In short, these terms refer to countries that "have not yet achieved, but generally aspire to, self-sustaining economic growth." ${ }^{35}$

\section{B. The Early Law and Development Movement}

The law and development movement was born in the mid-1960s at leading American law schools such as Harvard, Stanford, Wisconsin, and Yale. ${ }^{36}$ The movement adhered to the basic premise of modernization theory "that development was an inevitable, evolutionary process of increasing societal differentiation that would ultimately produce economic, political, and social institutions similar to those in the West." ${ }^{37}$

35. David M. Trubek, Toward a Social Theory of Law: An Essay on the Study of Law and Development, 82 YALE L.J. 1, 2 (1972); see MICHAEL P. TODARO, ECONOMIC DEVELOPMENT IN THE THIRD WORLD 27 (4th ed. 1989). I am not suggesting that development will ultimately produce institutions similar to those in the West. On the contrary, one of the major questions addressed in this Article is whether Western institutions can be grafted without significant adaptations onto the particular ethnic and nationalist structures of the developing world. Compare ANN SEIDMAN \& ROBERT B. SEIDMAN, STATE AND LAW IN THE DEVELOPMENT PROCESS 44-51 (1994) (describing the "almost universal failure" of developing countries' attempts to copy the laws of seemingly successful developed countries), with Donald L. Horowitz, The Qur'an and the Common Law: Islamic Law Reform and the Theory of Legal Change, 42 AM. J. COMP. L. 233, 267-73, 574 (1994) (describing the successful incorporation of English law into Malaysian Islamic law).

36. See Elliot M. Burg, Law and Development: A Review of the Literature and a Critique of "Scholars in Self-Estrangement," 25 AM. J. CoMP. L. 492, 495-97 (1977); John H. Merryman, Comparative Law and Social Change: On the Origins, Style, Decline \& Revival of the Law and Development Movement, 25 AM. J. COMP. L. 457, 457-58 n.4 (1977). The movement received substantial support from institutions such as the Ford Foundation and the U.S. Agency for International Development. See Merryman, supra, at 457. Others have chronicled the law and development movement in much greater detail. See, e.g., JAMES A. GARDNER, LEGAL IMPERIALISM: AMERICAN LAWYERS AND FOREIGN AID IN LATIN AMERICA 6-12, 45-47, 231-35 (1980) (tracing the history of the law and development movement in American institutions); David M. Trubek, Back to the Future: The Short, Happy Life of the Law and Society Movement, 18 FLA. ST. U. L. REV. 4, 23-24 (1990) (same). For particularly incisive overviews and critiques of the law and development movement, see Richard Bilder \& Brian Z. Tamanaha, The Lessons of Law-and-Development Studies, 89 AM. J. INT'L L. 470 (1995) (reviewing LAW AND DEVELOPMENT (Anthony Carty ed., 1992)); and LAW AND CRISIS IN THE THIRD WORLD (Sammy Adelman \& Abdul Paliwala eds., 1993). A good partial list of law and development work from the sixties can be found in Trubek, supra note 35, at 3-4 n.7.

37. Bilder \& Tamanaha, supra note 36 , at 471 . According to modernization theory (which arose in the wake of World War II principally through the efforts of American economists, political scientists, and sociologists), political development required four elements: (1) rationalization, involving "movement from particularism to universalism, from diffuseness to specificity, from ascription to achievement, and from affectivity to affective neutrality"; (2) national integration or "nation-building"; (3) democratization, emphasizing pluralism, competitiveness, and equality; and (4) mobilization or participation, to be achieved through "increases in literacy, urbanization, exposure to mass media, industrialization," and so on. Samuel P. Huntington, Political Development and Decay, in PolitiCAL SYSTEM AND CHANGE 95, 96-97 (Ikuo Kabashima \& Lynn T. White III eds., 1986); see also DAVID E. APTER, RETHINKING DEVELOPMENT: MODERNIZATION, DEPENDENCY, AND POST-MODERN POLITICS 16 (1987) (describing one goal of modernization theory as "the recapitulation in nonindustrial settings of the functional roles, classes, and reciprocities that appeared first in the old 'metropoles"'). 
Emphasizing the importance of law in the development of a market economy and democratic values, ${ }^{38}$ law and development scholars attempted to assist developing countries in establishing Western-style legal institutions. ${ }^{39}$ In so doing, the law and development movement selfconsciously sought to supplant Third World "localism," "irregularity, and particularism" with the "unity, uniformity, and universality" of the modern Western state. ${ }^{40}$ Ethnic identity and ethnic conflict were aspects of traditionalism or "pre-modernity" that in the course of development "were ultimately supposed to disappear." 41 The ultimate goal of the development process was to be the creation of a free-market system (which in turn would bring economic growth), liberal democratic government institutions, and the rule of law. ${ }^{42}$

By the mid-1970s, barely a decade after its inception, the law and development movement had fallen into open crisis. ${ }^{43}$ In a well-known piece entitled Scholars in Self-Estrangement: Some Reflections on the Crisis in Law and Development Studies in the United States, ${ }^{44}$ Professors Trubek and Galanter criticized the paradigm of "liberal legalism," which they had

38. Law was seen as essential to the creation and maintenance of markets. Because of its "predictability as a set of universal rules uniformly applied. . . . modern law encourages men to engage in new forms of economic activity and guarantees that the fruits of this activity will be protected." Trubek, supra note 35, at 7 . At the same time, by restraining arbitrary or oppressive government action, law would foster political development and serve as the foundation of the liberal democratic state. See Kenneth L. Karst, Law in Developing Countries, 60 L. LIBR. J. 13, 16-19 (1967); Trubek, supra note 35, at 8-9.

39. For example, American legal scholars urged and participated in the development of capital market programs, which were supposed to foster the development of Westem-style regulatory regimes and systems of private rights. See Trubek, supra note 35, at 45-46. The hope was that capital markets "would demand 'modem' substantive codes, a more stable and coherent body of laws, a reduction in government ad hoc decisionmaking, judicial reform, rationality in legal thought, and a restructuring of professional organization." Id. at 46. Educational reform was another primary emphasis of the law and development movement. See, e.g., Karst, supra note 38, at 19 (calling for a "radical re-ordering of legal education" in the developing world); Trubek, supra note 36, at 23 ("We devised grand programs to re-educate Third World lawyers .... By exporting the educational techniques of the American law school-socratic method, social science, and all-we would strengthen legal institutions just as AID agricultural technicians were transforming small, yellow eggs into large, white ones.").

40. Marc Galanter, Modernization of Law, in MODERNiZATION: THE DYNAMICS OF GROWTH 153, 154-55, 157 (Myron Weiner ed., 1966); see Trubek, supra note 35, at 9.

41. Bjöm Hettne, Ethnicity and Development: An Elusive Relationship, in ETHNICITY AND DEVElopMent: GeOGRAPHICAL PERSPECTIVES 15, 15 (Denis Dwyer \& David Drakakis-Smith eds., 1996) (discussing modernization theory).

42. See Trubek, supra note 35, at 6-9; Bilder \& Tamanaha, supra note 36, at 471; see also Trubek, supra note 36 , at 23 (describing retrospectively the mission of the early law and development movement as "exporting democratic capitalism" to countries seen as "too poor or benighted to grasp the possibilities of this superior form of civilization").

43. This onset of crisis roughly coincided with the civil rights movement and anti-Vietnam War protests, which were calling into question the American system and ideals. See Bilder \& Tamanaha, supra note 36 , at 472 .

44. David M. Trubek \& Marc Galanter, Scholars in Self-Estrangement: Some Reflections on the Crisis in Law and Development Studies in the United States, 1974 Wrs. L. REv. 1062. 
previously championed, as being "ethnocentric and naive." ${ }^{45}$ Liberal legalism, they argued, ignored the severe "social stratification and class cleavage" in developing societies and failed to recognize that "in much of the Third World the grip of tribe, clan, and local community is far stronger than that of the nation-state." ${ }^{46}$ More radically, Trubek and Galanter challenged the institution of law itself, suggesting that even in countries such as the United States the legal system reinforces "domination by elite groups" and legitimates "arbitrary actions by government." 47

Not long after the publication of Scholars in Self-Estrangement, "the law and development movement in the United States all but expired. Money stopped flowing from foundations. Various institutes and programs dedicated to the subject were scaled back or terminated. The scholars involved moved on to other pursuits." ${ }^{48}$ Since that time, numerous scholars have pondered the "death" of the law and development field. ${ }^{49} \mathrm{~A}$ few have even written "memoirs." 50 As I will suggest, however, the epitaph remains to be written.

\section{Law and Development Today}

Despite the demise of the early law and development movement, American lawyers and legal scholars today are helping to shape the fundamental economic and political institutions of the developing world to an extent unprecedented since decolonization. ${ }^{51}$ Much has changed about the law and development field. Today, many of the lawyers most centrally involved in the developing world are law and economics luminaries, constitutional designers, and Wall Street practitioners. With some exceptions, legal work on development is more sophisticated than ever.

45. Id. at $1070,1080$.

46. Id. at 1080 (citation omitted). In addition, liberal legalism assumed the existence of an independent judiciary, whereas developing countries' courts were typically weak and captured by "political, tribal, religious, or class interests." Id. at 1080-81. Moreover, legal rules in the Third World principally served the interests of the elite and rarely were internalized by the vast majority of the population. See id.

47. Id. at 1083 .

48. Bilder \& Tamanaha, supra note 36 , at 474 .

49. See, e.g., Introduction to LAW AND DEVELOPMENT, supra note 36, at xi ("[L]aw and development has been so marked by controversy ... it can be said to be almost stillborn ...."); Merryman, supra note 36, at 460 ("Are we witnessing the death of a field, the realization that one was never born ... or what?").

50. See, e.g., Trubek, supra note 36, at 5 (offering "more than a memoir [but] less than a history" of the movement).

51. See, e.g., Donald L. Horowitz, Democracy in Divided Societies, 4 J. DEMOCRACY 18, 35 (1993); Lisa Brennan, Firms Thrive on Asia Woes, NAT'L L.J., Feb. 23, 1998, at A1; Virginia Citrano, Shrinking Governments Fatten City Firms, CraIN's N.Y. BuS., Jan. 11, 1993, at 11; Wendy Cooper \& Harvey D. Shapiro, Privatization of Privatization, INSTTTUTIONAL INVESTOR, Oct. 1991, at 87, 89 . 
Moreover, the disintegration of the former Communist bloc has raised a host of challenging legal issues of first impression.

Nevertheless, the thrust of international development policy today remains essentially what it was in the sixties and seventies: to export markets, democracy, and the rule of law to the developing world. In this Section, I will first survey the current literature relating to law in the developing world. This literature is highly interdisciplinary, including political scientists and economists among its leading contributors. I will limit my discussion here to work directed at the legal community or relating specifically to legal institutions. I will then discuss international development policy and practice.

\section{The Current Literature}

Today's law and development literature can be divided into two broad categories. First, a relatively small number of scholars who consciously identify themselves with law and development have generally picked up where the movement of the 1960s and 1970s left off. Often associated with "leftist" causes, these scholars continue in their writings to struggle with a host of difficult and profound issues, such as law's impotence or "epiphenomenality" $; 2$ its disingenuous claims to neutrality ${ }^{53}$ its ethnocentricity; ${ }^{54}$ and its "infamy" in contributing to the oppression of the disempowered. ${ }^{55}$

In terms of sheer volume and actual influence, however, by far the more massive contribution to the law and development literature has been made by lawyers who probably do not think of themselves as law and development "types." This second category includes practitioner-written pieces as well as a much more theoretical academic literature.

52. See, e.g., Sammy Adelman \& A. Caesar Espiritu, Debt Crisis, Underdevelopment and the Limits of the Law, in LAW AND CRISIS IN THE THIRD WORLD, supra note 36, at 172, 182 (stating that the role played by law in the debt crisis of the 1980 s was "largely epiphenomenal"); Bilder \& Tamanaha, supra note 36 , at 486 .

53. See, e.g., Yash Ghai, Constitutions and Governance in Africa: A Prolegomenon, in LAW AND CRISIS IN THE THIRD WORLD, supra note 36, at 51, 55 (suggesting that despite law's appearance of autonomy and neutrality it "is a powerful means for the legitimation of Westem regimes, and is carefully cultivated by their rulers").

54. See, e.g., RAJNI KothaRI, RETHINKING DEVElopMENT: IN SEARCH OF HuMANE ALTERNATIVES 192-93 (1989) (describing modernity's paranoid drive to fashion the world after the Occidental ideal); Adeno Addis, Individualism, Communitarianism, and the Rights of Ethnic Minorities, 67 NOTRE DAME L. REV. 615, 618-19 (1992) (critiquing prevailing views of democracy and development that are incompatible with the affirmation of ethnic differences); $c f$. Bilder \& Tamanaha, supra note 36 , at 481-82 (discussing the tensions inherent in claims of law's ethnocentrism).

55. Peter Fitzpatrick, Law's Infamy, in LAW AND CRISIS IN THE THIRD WORLD, supra note 36 , at 27,27 (suggesting "that the blithe advocacy of law in the cause of development is flawed in its very foundation"). 
In the last five years, there have been hundreds of articles written by legal practitioners involved in the developing world. ${ }^{56}$ In Professor Mark Sidel's words, " $[t]$ his output is almost entirely descriptive and oriented in a wholly instrumental fashion to the requirements of trade and investment." 57 Typical topics include trade and foreign investment regulation, taxation and tax policy, banking law, concession law, dispute resolution, and technology transfer. ${ }^{58}$ Professor Sidel is correct in cautioning that "[w]e should not impose an entirely scholarly lens on materials written, primarily, for practical, utilitarian reasons." ${ }^{59}$ Still, it is noteworthy that the overwhelming thrust of this massive body of legal commentary is to urge the rapid and full-blown liberalization and marketization of developing world economies $^{60}$ (hardly surprising when one considers the financial interests involved).

Alongside this practitioner-oriented work, there is also a large academic literature relating to today's developing world transformations. Most of this literature too can be characterized as addressing either marketization or democratization. As to marketization, a significant part of the literature addresses, from a variety of perspectives, the transitions from command to market economies in the countries of the former Soviet bloc. ${ }^{61}$ The more halting market-oriented reforms of Cambodia, China, Vietnam, and other nominally Communist countries also have generated a proliferating body of

56. For a tiny sampling of such practitioner-oriented output, see infra note 599 , listing recent articles on Vietnam.

57. Mark Sidel, New Directions in the Study of Vietnamese Law, 17 MrCH. J. INT'L L. 705, 713 (1996) (reviewing VIETNAM AND THE RULE OF LAW (Carlye A. Thayer \& David G. Marr eds., 1993)).

58. See id. at 712 .

59. Id. at 714 .

60. See, e.g., Emil Bukhman, The Cart Before the Horse: Anticipatory Securities Regulation in Kazakhstan, 22 BROOK. J. INT'L L. 535 (1997); Danny E. Reed, Creating Competitive Market Economies in Poland and Hungary, 48 ADMIN. L. REv. 515, 516 (1996); Matias F. Travieso-Diaz \& Alejandro Ferrate, Recommended Features of a Foreign Investment Code for Cuba's Free Market Transition, 21 N.C. J. INT'L L. \& COM. REG. 511 (1996); Pham van Thuyet, Legal Framework and Private Sector Development in Transitional Economies: The Case of Viet-nam, 27 LAW \& POL'Y INT'L BUS. 541, 596 (1996).

61. See, e.g., E. Donald Elliott, Environmental Protection and the Development of Free Markets in Russia, in LAW AND DEMOCRACY IN THE NEW RUSSIA 107, 108-11 (Bruce L.R. Smith \& Gennady M. Danilenko eds., 1993) (offering a comparative environmental perspective); Michael A. Heller, The Tragedy of the Anticommons Property in the Transition from Marx to Markets, 111 HARV. L. REV. 621 (1998) (presenting a property perspective). Professors Roman Frydman and Andrzej Rapaczynski have made especially notable contributions to this area. For nearly a decade now, they have studied the post-Soviet transitions, beginning with the early implementation stage. See ROMAN FRYDMAN ET AL., THE PRIVATIZATION PROCESS IN CENTRAL EUROPE (1993) (describing the privatization process and relevant legal framework in Central Europe). They have focused most recently on the problem of "overwhelming insider-domination of [Russia's] privatized firms." Roman Frydman et al., Investing in Insider-Dominated Firms: A Study of Russian Voucher Privatization Funds, in CORPORATE GOVERNANCE IN CENTRAL EUROPE AND RUSSIA 187, 189 (Roman Frydman et al. eds., 1996). 
commentary ${ }^{62}$ More generally, there have been dozens of recent law review articles seeking to assist developing countries in their economic liberalizations..$^{63}$ As with marketization, the work on democratization in the developing world varies considerably in scope and quality. Besides the massive political science literature on this subject, ${ }^{64}$ there is also a growing body of work by lawyers and legal academics struggling with the issue of the transplantability of Western-style democratic and rule-of-law institutions in countries with vastly different histories and social structures. This work ranges from highly abstract treatments; ${ }^{65}$ to region- or countryspecific studies of democracy's preconditions, ${ }^{66}$ optimal institutions, ${ }^{67}$ or

62. See, e.g., William P. Alford, Tasselled Loafers for Barefoot Lawyers: Transformation and Tension in the World of Chinese Legal Workers, CHINA Q., Mar. 1995, at 22; Lan Cao, The Cat That Catches Mice: China's Challenge to the Dominant Privatization Model, 21 BROOK. J. INT'L L. 97 (1995); John T. Philipsborn, As Law Returns to the "Killing Fields," 76 JUDICATURE 204 (1993) (discussing Cambodia); Mark Sidel, Law Reform in Vietnam: The Complex Transition from Socialism and Soviet Models in Legal Scholarship and Training, 11 UCLA PAC. BASIN L.J. 221 (1993); Mark Sidel, The Re-emergence of Legal Discourse in Vietnam, 43 INT'L \& COMP. L.Q. 163 (1994); William H. Simon, The Legal Structure of the Chinese "Socialist Market" Enterprise, 21 J. CORP. L. 267 (1996).

63. For particularly thoughtful treatments, see, for example, Enrique R. Carrasco \& Randall Thomas, Encouraging Relational Investment and Controlling Portfolio Investment in Developing Countries in the Aftermath of the Mexican Financial Crisis, 34 COLUM. J. TRANSNAT'L L. 539 (1996); and David W. Leebron, A Game Theoretic Approach to the Regulation of Foreign Direct Investment and the Multinational Corporation, 60 U. CIN. L. REv. 305 (1991). In addition, the Asian Development Bank has compiled an excellent bibliography of academic literature on law and development in the Asia-Pacific region. See OFFICE OF THE GEN. COUNSEL, ASIAN DEv. BANK, LAW AND DEVELOPMENT: AN ASIAN BIBLIOGRAPHY (1997).

64. For influential texts in this area, see BARRINGTON MOORE, JR., SOCLAL ORIGINS OF DictatoRshIP AND DEMOCRACY: LORD AND PEASANT IN THE MAKING OF THE MODERN WORLD 418-32 (1966), which suggests that conditions are more propitious for democracy where the social and economic power of the landed aristocracy is in decline relative to that of the bourgeoisie; Fernando Henrique Cardoso, Associated-Dependent Development: Theoretical and Practical Implications, in AUTHORITARIANISM IN BRAZIL 142, 146-48 (Alfred Stepan ed., 1973), which argues that international capitalism played an important role in facilitating the 1964 military overthrow of the Brazilian populist regime; Samuel P. Huntington, Will Cotmtries Become More Democratic?, 99 POL. SCI. Q. 193, 205-07 (1984), which links the success of democracy in developing countries to U.S. foreign policy; Seymour Martin Lipset, Some Social Requisites of Democracy: Economic Development and Political Legitimacy, 53 AM. POL. SCI. REV. 69, 75-77 (1959), which notes that "the more well-to-do a nation, the greater the chances that it will sustain democracy"; and Dankwart A. Rustow, Transitions to Democracy: Toward a Dynamic Model, 3 COMP. POL. 337, 350, 361-63 (1970), which proposes a model of democratization premised on the condition of national unity. For an excellent compilation of work on democratic transitions in the developing world, see generally TRANSITIONS TO DEMOCRACY, supra note 27.

65. See, e.g., Roberto MANGabeIRA Unger, False NeCESSITY: ANTI-NECESSITARIAN SOCIAL THEORY IN THE SERVICE OF RADICAL DEMOCRACY 5-11, 341-595 (1987) (criticizing current democratic institutions and advocating instead a program of "empowered democracy").

66. See, e.g., Frances H. Foster, Information and the Problem of Democracy: The Russian Experience, 44 AM. J. COMP. L. 243, 275 (1996) (observing that Russians cannot draw on a common cultural understanding to lend meaning and legitimacy to constitutional guarantees of free speech and information); Stephen Holmes, Crime and Corruption After Communism, E. EUR. CONST. REV., Fall 1997, at 69, 69 (stating that a major obstacle to constitutionalism and the rule of law in postcommunist countries is "the interweaving of private-sector crime with public-sector corruption”); Andrew S. Levin, Civil Society and Democratization in Haiti, 9 EMORY INT'L L. 
effects; ${ }^{68}$ to "on-the-ground," village-to-village analyses of local
governmental processes. ${ }^{69}$

\section{Policy and Practice}

Consistent with the vast part of the law and development literature, the ideology of free-market democracy forms the theoretical core of today's international development policy and practice. $^{70}$ This ideology is propagated by the two institutions wielding by far the greatest influence on the developing world-the World Bank and the International Monetary Fund $^{71}$-as well as by the United States Agency for International

REV. 389, 392 (1995) (arguing through the example of Haiti "that the vitality and growth of civil society are key factors in indigenous efforts to democratize developing countries"); Offe, supra note 3, at 64, 65 (discussing the troubling absence in Eastern Europe of the "cultural foundations" necessary to support the new market and democratic institutions).

67. See, e.g., Jon Elster, Constitutional Courts and Central Banks: Suicide Prevention or Suicide Pact?, E. EUR. CONST. REV., Summer/Fall 1994, at 66 (arguing that establishing constitutional courts and central banks in Eastern Europe might undermine as well as protect democracy); Cass Sunstein, Against Positive Rights, E. EUR. CoNST. REV., Winter 1993, at 35, 35-36 (criticizing the inclusion of social and economic rights in the new constitutions of postcommunist Europe); Laura Underkuffler-Freund, Property: A Special Right, 71 NOTRE DAME L. REV. 1033, 1045-46 (suggesting that the inclusion of social and economic rights in some developing country constitutions may be appropriate). Consider also the three-way discussion among Professors Horowitz, Linz, and Lipset on the merits of parliamentarism as opposed to presidentialism. Compare Donald L. Horowitz, Comparing Democratic Systems, J. DEMOCRACY, Fall 1990, at 73, 74 (noting that democratic parliamentarism in many developing countries has failed), with Juan J. Linz, The Perils of Presidentialism, J. DEMOCRACY, Winter 1990, at 51, 52 (suggesting that parliamentary systems are "more conducive to stable democracy" than are presidential systems), and Seymour Martin Lipset, The Centrality of Political Culture: The Virtues of Parliamentarism, J. DEMOCRACY, Winter 1990, at 80, 82-83 (emphasizing the importance of cultural factors to stable democracy).

68. See, e.g., Cynthia B. Schultz \& Tamara Raye Crockett, Economic Development, Democratization, and Environmental Protection in Eastern Europe, 18 B.C. ENVTL. AFF. L. REv. 53, 53, 62-63 (1990) (arguing that democratization in Eastern Europe has heightened concern for environmental protection, which in turn has fostered democratization); Emily Stoper \& Emilia Ianeva, Democratization and Women's Employment Policy in Post-Communist Bulgaria, 12 CONN. J. INT'L L. 9, 10 (1996) (suggesting that democratization is unlikely to have a significant impact on women's employment policies in Bulgaria).

69. See, e.g., Brian Z. Tamanaha, The Role of Custom and Traditional Leaders Under the Yap Constitution, 10 U. HAW. L. REv. 81, 94-97, 103 (1988) (describing the persistence of custom and traditionalism in Micronesian politics despite a U.S.-style constitution); Jonathan Hecht, Half-Cooked Rice and Pearls from the Sea: The Uses and Limits of Law in the Development of China's Villagers Committee System (Apr. 16, 1997) (paper presented to the Conference on Local Self-Government in Mainland China, Hong Kong, and Taiwan, Duke University, May 1997) (unpublished manuscript, on file with The Yale Law Journal) (studying the relationship between law and democracy in the context of China's villagers committee system).

70. Cf. UNGER, supra note 2 (manuscript at 3 ) (referring to the prevailing "neoliberal program" and "its defining belief in convergence toward a single system of democratic and market institutions"); Peter L. Berger, The Uncertain Triumph of Democratic Capitalism, in CAPITALISM, SOCIALISM, AND DEMOCRACY REVISITED, supra note 17, at 1, 8 (describing the current "triumphalism among those who believe in democracy and capitalism").

71. See, e.g., SUSAN GEORGE \& Fabrizio SABELli, Full FAITH AND CREdIT: THE WORLD BANK'S SECULAR EMPIRE 2, 4, 8-9, 13, 19 (1994) (stating that the World Bank's structural 
Development (USAID), ${ }^{72}$ the Asian Development Bank, ${ }^{73}$ the Ford Foundation, ${ }^{74}$ the Soros Foundation, ${ }^{75}$ the United Nations Development Programme, ${ }^{76}$ the American Bar Association's Central and East European Law Initiative, ${ }^{77}$ and a host of new private or quasi-private organizations with names like "The Institute for Public-Private Partnerships" " or "The Democracy Development Initiative." ${ }^{79}$ Moreover, many academics involved in the developing world are working in some capacity to promote markets ${ }^{80}$ or democracy. ${ }^{81}$ Even law students are marketizing: The

adjustment loans have re-oriented entire economies toward individualistic, free-market "Reaganomics"); Law and Development in Crisis, in LAW AND CRISIS IN THE THIRD IWORLD, supra note 36, at 1-2 (criticizing the hypocrisy and imperialism hidden in the orthodoxy of liberal democracy championed by the IMF and the World Bank); DANI RODRIK, KNG KONG MEETS GodzILla: The WORLD BANK AND THE EAST ASIAN MIRACle 1 (Centre for Econ. Pol'y Res. Discussion Paper No. 944, 1994) (noting that as "the world's leading multilateral lending institution, the World Bank has advocated, at least since the late 1970s, a minimalist role for the government"); Offe, supra note 3, at 65 (suggesting that in Eastern Europe "Western"-style markets and democracy were presented as preconditions for assistance and cooperation from multilateral organizations such as the European Union, NATO, and the MMF).

72. See Asian Development Bank, A Periodic Summary of Law-Related Projects in the AsiaPacific Region, Conducted by the Bank and by Other Multilateral Institutions, Bilateral Assistance Institutions, Academics and the Private Sector, LAW DEV. BULL., Nov. 1997, at 6, $15-$ $17,53,59-60,87-88,90,97-98$ (describing programs sponsored by USAID).

73. "The [Asian Development] Bank's principal focus is on working with [developing member countries] seeking to develop or liberalize market economies ...." Barry Metzger, Emerging Trends and Issues in Legal and Judicial Reform in Asia-Perspectives and Programming at the Asian Development Bank, Remarks at the Proceedings of the Roundtable Meeting of Chief Justices and Ministers of Justice (Aug. 25, 1997), in LAW \& DEV.: SEMIINAR PROC., 1997, at 8, 13. While the Bank has promoted judicial reform, its motivation (at least ostensibly) has been economic-and not political-in character. See id. at 8-11 (describing the economic orientation of recent legal and judicial reforms supported by the Bank); see also Asian Development Bank, supra note 72, at 19-20, 41-43, 72-74, 80-82, 88-89 (describing Banksponsored marketization projects in China, India, Lao People's Democratic Republic, Mongolia, and Nepal).

74. See Asian Development Bank, supra note 72, at 31. The Ford Foundation dispenses grants "to strengthen democratic values ... and advance human achievement around the world." Judith Havemann, Lilly Endowment Is Nation's Top Giver, WASH. POST, Feb. 15, 1998, at A17 (internal quotation marks omitted).

75. See SOROS, supra note 1 , at 6-10.

76. See Asian Development Bank, supra note 72 , at 13, 36-37, 113-15.

77. See Robert A. Stein, Lending Freedom a Hand: CEELI Brings American Legal KnowHow to Bosnia-Herzegovina, A.B.A. J., Apr. 1996, at 101, 101; ABA (CEELI), ASSISTING EMERGING DEMOCRACIES (on file with The Yale Law Journal); ABA (CEELI), GUIDELINES FOR ASSESSING DRAFT LAWS (on file with The Yale Law Journal).

78. See Michael P. MClindon, PRIVATization and Capital Market Development: STRATEGIES TO PROMOTE ECONOMIC GROWTH at Xviii (1996).

79. See Alfred F. Belcuore, Meeting the Founders: Russians and Kazakhs Work for Democracy, 25 LAW \& POL'Y INT'L BUS. 461, 461 (1994).

80. Scholars regularly participate (for example, through CEELI) in the process of drafting market-oriented laws. See, e.g., ABA (CEELI), ANALYSIS OF THE DRAFT LAW ON FOREIGN INVESTMENT FOR THE FEDERATION OF BOSNIA AND HERZEGOVINA (June 1, 1995); ANALYSIS OF NIZHNY NOVGOROD INVESTMENT LAW, supra note 6. In addition, a growing number of academics, often in conjunction with institutions such as the Ford Foundation or the Soros Foundation, advise developing governments on the development of transitional market mechanisms. See, e.g., FRYDMAN ET AL., supra note 61, at $\mathrm{x}$-xiii. 
government of Estonia recently asked six Georgetown law students and their professors "to help determine what types of laws are required to start a free-market system." 82

Additionally, unlike in the 1960s and 1970s, the field of law and development today is shaped significantly by legal practitioners. There is no question that practitioner-structured market interventions such as privatization (frequently of telecommunications enterprises or major utilities), ${ }^{33}$ cross-border offerings, ${ }^{84}$ or international mergers and joint venture ${ }^{35}$ are having a tremendous impact on the economic landscape of many developing and transitional countries. Indeed, because international business transactions often mean potential profits in the order of hundreds of millions of dollars ${ }^{86}$ - often much more than multilateral lending institutions can offer-practicing lawyers wield decisive influence over developing governments.

\section{The Problem in the Current Paradigm}

Despite frequent claims of "new paradigms" ${ }^{87}$ and "lessons learned," 88 prevailing law and development orthodoxy recapitulates a basic and

81. For example, law professors frequently assist in drafting constitutional provisions, see LUDWIKOWSKI, supra note 7, at 2-3, and in training judges, lawyers, and government officials in developing countries, see Belcuore, supra note 79, at 461-62, 464-65; Stein, supra note 77, at 101.

82. Brooke A. Masters, GU Legal Eagles Flying to Estonia's Aid, WASH. POST, June 18, 1992, at D3. Reportedly, some of the students had "never studied antitrust law, the area they [we]re summarizing for the Estonians. 'We look with a fresh eye, so we're suggesting things that are not necessarily American or European,' said one student." Id. The Georgetown-Estonia project was funded by the U.S. Commerce Department's Commercial Law and Development Program for Eastern Europe. See id.

83. The landmark privatization of Teléfonos de México (Telmex), for example, was structured and conducted in significant part by two Wall Street law firms, Cleary, Gottlieb, Steen \& Hamilton and Sullivan \& Cromwell, working together together with Goldman, Sachs, Mexican government officials, and local Mexican counsel. See Prospectus of Teléfonos de México, S.A. de C.V. at 67 (May 11, 1992) (on file with The Yale Law Journal). U.S. law firms also helped privatize the national telephone companies of Argentina and Venezuela. See Susan Beck, Big Deals: International, AM. LAw., Mar. 1992, at 44; Susan Carter \& Craig Leon, Foreign Investment: The Floodgates Open, INSTITUTIONAL INVESTOR, Mar. 1998, at S20.

84. See, e.g., Richard Forster \& Robert Dwyer, Linklaters Takes Lead as Firms Build for the Future, 16 INT'L FiN. L. REv. 21, 24 (1997) (describing recent cross-border securities offerings in Russia and Eastern Europe).

85. See, e.g., John J. McKenna, North American Firms Compete for Latin American Investments, OIL \& GAS J., Feb. 23, 1998, at 26, 26-27 (describing the recent wave of jointventure and merger-and-acquisition activity in the Latin American energy sector).

86. See Carter \& Leon, supra note 83, at S20; Forster \& Dwyer, supra note 84, at 21-28; McKenna, supra note 85 , at 26.

S7. See, e.g., THE WORLD BANK GROUP, supra note 2, at 10 (stating that "[a] new development paradigm has emerged, one that emphasizes market friendly approaches and stresses the importance of private sector development").

88. See, e.g., Mary M. Shirley, The What, Why, and How of Privatization: A World Bank Perspective, 60 FORDHAM L. REv. S23, S31-S32 (1992) ("The present interest in privatization is no fad. .. . Lessons have been learned ... and today's strategies reflect these lessons."). 
potentially fatal error of the earlier movement. It ignores ethnicity and ethnic conflict in the developing world. To be sure, ethnic conflict figures prominently in the human rights area ${ }^{89}$ particularly in the context of war crimes. ${ }^{90}$ But the distinctive, structural relationship between ethnicity and today's marketization and democratization efforts has been almost completely overlooked by all lawyers and legal scholars involved in the developing world, including those in the human rights area.

Why this has been so is itself fascinating. Practitioners probably view ethnic tensions as lying far beyond the scope of their responsibility. ${ }^{91}$ Law and economics scholars involved in marketization also tend to treat ethnic conflict as beyond the scope of their analyses, ${ }^{92}$ although all behavior can be described as preference-maximizing in a tautological sense, the "preferences" and behaviors associated with ethnic hatred escape the kind of rationality assumed in most economic models. ${ }^{93}$ Moreover, Western discomfort with potentially invidious ethnic generalizations may go a long way toward explaining the neglect of the ethnic dimensions of markets and democracy in the developing world..$^{94}$

For whatever reason, today's dominant law and development orthodoxy regards ethnic conflict as just another aspect of underdevelopment, which the universal prescription of markets and democracy is supposed to cure. This Article challenges the prevailing orthodoxy. The particular ethnic dynamics of many postsocialist and developing countries introduce deep

89. See, e.g., International Convention on the Elimination of All Forms of Racial Discrimination, opened for signature Mar. 7, 1966, 660 U.N.T.S. 195, 5 I.L.M. 352.

90. See, e.g., Madeline H. Morris, The Trials of Concurrent Jurisdiction: The Case of Rwanda, 7 DUKE J. COMP. \& INT'L L. 349 (1997); Ruth Wedgwood, The Case for a Permanent War Crimes Court, CHRISTIAN SCr. MONITOR, Aug. 16, 1995, at 18.

91. See generally ANTHONY KRONMAN, THE LOST LAWYER (1993) (lamenting the narrow technical focus of most practicing lawyers); WILLIAM H. SIMON, THE PRACTICE OF JUSTICE 8-9 (1998) (suggesting that the prevailing approach to lawyers' ethics severely restricts the range of factors that lawyers may consider in decisionmaking).

92. In a related vein, Professor Mark Roe has observed that law and economics analysis tends to be "American-centered" to the extent that it ignores the "risk of institutionally-induced turmoil" and backlash present in less politically stable countries. Mark J. Roe, Backlash, 98 COLUM. L. REV. 217, 217-20, 239 (1998).

93. Most economic models assume maximization of economic value by individuals whereas "[i]n fact both state officials and social actors may be motivated by ends which are primarily noneconomic such as racism or ethnicity." Mushtaq $H$. Khan, Patron-Client Networks and the Economic Effects of Corruption in Asia 10 (Winter 1997) (unpublished manuscript, on file with The Yale Law Journal); see also Richard H. McAdams, Cooperation and Conflict: The Economics of Group Status Production and Race Discrimination, 108 HARV. L. REV. 1003, 1007-08 (1995) (suggesting that current economic theory focuses insufficiently on group loyalty and group identity and thus "fails to predict the prevalence of cooperation and conflict in human affairs").

94. Even among the relatively few left-wing law and development scholars who still challenge the orthodoxy of free-market democracy, ethnicity tends to be neglected in favor of class-based analyses. See Hettne, supra note 41, at 15 (observing that for Marxists concerned with development issues ethnic mobilization is usually described "as a class struggle in disguise"). For a more nuanced view of the relationship between ethnicity and class that still suggests the ultimate centrality of class conflict, see UNGER, supra note 2 (manuscript at 103-08). 
tensions into the very project of marketization and democratization. These tensions, if left unaddressed, threaten to undermine the long-term success of the development project.

\section{UNDERDEVELOPMENT AND OVERACHIEVEMENT}

This Part will explore the ethnoeconomics of the developing world and highlight the prevalence of economically dominant ethnic minorities throughout South and Southeast Asia, Africa, the Caribbean, Latin America, and parts of the former Soviet Union. The reasons for, and the circumstances surrounding, the economic dominance of these minority groups at either the national or regional level vary enormously. In particular, some groups may be economically dominant but not marketdominant. That is, some groups may owe their economic dominance, in part or in whole, not to superior "entrepreneurialism" but rather to factors that will not persist under market conditions. The distinction between marketdominant minorities and minorities that are not market-dominant lies at the heart of the model developed in Part IV.

\section{A. Ethnoeconomics in the Developing World}

Although legal scholars almost never acknowledge the phenomenon, historians and sociologists of the developing world long have recognized the presence of one or more ethnic minorities who historically have dominated economically the "indigenous" majorities around them. ${ }^{95}$ These minorities may be found in virtually every part of the developing world.

95. See generally JEAN-LOUP AMSELLE, LES NEGOCLANTS DE LA SAVANE 13, 20-21 (1977) (studying the commercially dominant Kooroko community in Mali); P.T. BAUER, WEST AFRICAN TRADE: A STUDY OF COMPETITION, OLIGOPOLY AND MONOPOLY IN A CHANGING ECONOMY $65-$ 76 (1954) (studying the economic role in West African trade and entrepreneurial activity played by African and non-African groups); ClIFFORD GEERTZ, PEDDLERS AND PRINCES: SOCIAL CHANGE AND ECONOMIC MODERNIZATION IN TWO INDONESIAN TOWNS 8-12, 51-53 (1963) (discussing the dominance of Chinese traders in Javanese society); FRANK H. GOLAY ET AL., UNDERDEVELOPMIENT AND ECONOMIC NATIONALISM IN SOUTHEAST ASIA 43, 115-17, 137, 166, 289, 395-97 (1969) (documenting the historical economic dominance of the Chinese in the Philippines, Indonesia, Thailand, and South Vietnam); THE LEBANESE IN THE WORLD 343, 349 , 389-91, 526-27, 598-99 (Albert Hourani \& Nadim Shehadi eds., 1992) (describing the economic success of Lebanese minorities in Latin America, the Caribbean, and West Africa); J.S. MANGAT, A HISTORY OF THE ASIANS IN EAST AFRICA 1-26 (1969) (discussing the historical origins of commercial dominance by Indians in East Africa); THOMAS SOWELL, RACE AND CULTURE 2 (1994) (noting that India's Gujaratis have been "prominent or predominant in business enterprises from Fiji to virtually the entire eastern coast of the African continent"); Edna Bonacich, $A$ Theory of Middleman Minorities, 38 AM. SoC. REV. 583, 589-92 (1973) (presenting a model to explain hostility against middleman minorities). 
For example, although Chinese affluence in Southeast Asia is well known, ${ }^{96}$ the persistence and extent of their economic power remain startling. In Indonesia, the Chinese represent less than five percent of the population but control "an estimated 70 percent of the country's private domestic capital and run three-quarters of its 200 largest businesses." ${ }^{97}$ In Thailand, the Chinese minority, roughly ten percent of the population, historically has dominated the country's major economic sectors, including all four of the country's largest private banks. ${ }^{98}$ Moreover, "[o]f the five billionaires in Indonesia and Thailand in the late twentieth century, all were ethnically Chinese." 99 In Malaysia, the relatively large Chinese minority (roughly thirty-two percent of the population ${ }^{100}$ ) historically dominated the country's manufacturing, mining, retail trade, transportation, and communications sectors" ${ }^{101}$ and still account "for the bulk of private economic activity in Malaysia, despite discriminatory laws aimed at limiting their clout." ${ }^{102}$ In the Philippines, the ostensibly "aggressive" Chinese (only about two percent of the population) reportedly control almost forty percent of the corporate economy, including the country's four major airlines. ${ }^{103}$ For centuries, the Chinese minority dominated small-scale industry in Laos and retail trade in Vietnam and Cambodia. ${ }^{104}$ In the southern part of Vietnam, the Chinese owned " 80 percent of all capital invested in the manufacturing of textiles, iron and steel, and chemical and allied products" as late as $1974 .{ }^{105}$ Today, as discussed further in Part V,

96. See, e.g., Dominique Turpin, Challenge of the Overseas Chinese, FIN. TIMES, Feb. 6, 1998 , at $\$$ (stating that "experts are unanimous that the overseas Chinese dominate medium- and large-scale corporate capital in all Asian markets except for Japan and Korea").

97. THOMAS SOWELl, MigRATIONS AND CUlTURES 176 (1996); see Leo Suryadinata, Indonesian Policies Toward the Chinese Minority Under the New Order, 16 ASLAN SURV. 770, 770 (1976).

98. See GOLAY ET AL., supra note 95, at 289; SOWELL, supra note 97, at 176; see also JAMES C. INGRAM, ECONOMIC CHANGE IN THAILAND 1850-1950, at 36-37, 55-57 (1971) (explaining that apart from rice cultivation, "an ancient and honorable occupation to the Thai," the Thais left most entrepreneurial functions to the Chinese).

99. SOWELl, supra note 97, at 176 (citing JOEL KOTKIN, TRIBES: HOW RACE, RELIGION, AND IDENTITY DETERMINE SUCCESS IN THE NEW GLOBAL ECONOMY 180 (1993)).

100. See WORLD ALMANAC AND BOOK OF FACTS 796 (Robert Famighetti ed., 1997).

101. See GolAY ET AL., supra note 95, at 350-52; RAJ K. VASIL, POLITICS IN BI-RACLAL SOCIETIES 203, $206 \&$ tbl.16 (1984) (citing Malaysian government statistics illustrating corporate dominance of Chinese in key economic sectors).

102. Keith B. Richburg, For Southeast Asia's Chinese, Success Breeds Discrimination, WASH. POST, Mar. 20, 1988, at A25.

103. See Cecil Morella, Ethnic Chinese Stay Ready, Hope to Ride out Crime Wave, AGENCE FR.-PRESSE, Apr. 30, 1996, available in LEXIS, News Library, AFP File; Richburg, supra note 102 , at A25.

104. See TRAN Khanh, THE ETHNic ChINESE AND ECONOMIC DEVELOPMENT IN VIETNAM 20-21 (1993); SOWELL, supra note 95, at 211 ("[The Chinese] owned approximately 70 percent of small-scale industry in Laos and conducted more than 70 percent of the retail trade in Vietnam and Cambodia."). 21.

105. SOWELL, supra note 97, at 211 (footnote omitted); see KHANH, supra note 104, at 20- 
economic liberalization in Vietnam has led to a resurgence of Chinese commercial dominance in the country's urban areas. ${ }^{105}$

The Chinese are not the only economically dominant minority in Asia. In Cambodia, the Vietnamese, who historically were viewed as more "frugal," "industrious," and trade-oriented than the Khmers, dominated certain skilled occupations. ${ }^{107}$ In Burma, colonial laissez-faire policies led to the disproportionate prosperity of the Indian minority relative to indigenous Burmese; together with the British and (to a lesser extent) the Chinese, the Indian minority dominated Burma's commercial sphere until the $1960 \mathrm{~s}^{108}$ In Sri Lanka, the Ceylon Tamils, historically more educated, prosperous, and "advanced" than the Sinhalese majority, dominated both the economic and political spheres until the mid-1950s. ${ }^{109}$ In Bombay, capital of the western Indian state of Maharashtra, "clever and very hardworking" South Indian "outsiders" traditionally dominated the powerful private sector vis-à-vis the Maharashtrians. ${ }^{110}$ In the Telangana region of India, the Telanganas were "no match" for the better-educated, "clever and cunning" people of the coastal Andhras." In Assam, an oilrich state in northern India, Bengali immigrants (now roughly forty percent of the population) historically have dominated commerce, professions, and, until a recent wave of ethnic reprisals, government bureaucracy. ${ }^{112}$

Moreover, this phenomenon is replicated throughout the countries of Africa, where entrepreneurial "pariah" (non-African) minorities ${ }^{113}$ coexist

106. See infra text accompanying notes $590 \& 610-611$.

107. Chou Meng Tarr, The Vietnamese Minority in Cambodia, RACE AND ClAss, Oct.-Nov. 1992, at 33, 34-35, 38; see Nayan Chanda, Wounds of History: Surging Resentment of Vietnamese Could Spark New Pogroms, FAR E. ECON. REV., July 30, 1992, at 14, 15-16.

108. See GolaY ET AL., supra note 95, at 210-11, 220-23, 251, 254; MARTIN SMTTH, BURMA: INSURGENCY AND THE POLITICS OF ETHNICITY 43-44 (1991).

109. See ChandRa R. DE SLlVA, SRI LANKA: A HistoRY 187, 236 (1987); B.H. FARMER, CEYLON: A DIVIDED NATION 51 (1963); HOROWITZ, supra note 10, at 155-56, 245-46, 616-17.

110. HOROWTZ, supra note 10, at 173-74 (citations omitted); see id. at 170; MARY FAINSOD KATZENSTEIN, ETHNiCITY AND EQUALITY: THE SHIV SENA PARTY AND PREFERENTIAL POLICIES IN BOMBAY 17-18, 30, 33 (1979).

111. HOROWTZ, supra note 10, at 167, 673-74 (citations omitted); see MYRON WEINER, SONS OF THE SOIL: MIGRATION AND ETHNIC CONFLICT IN INDIA 236-43 (1978). Telangana and coastal Andhra are both regions in the state of Andhra Pradesh. See WEINER, supra, at 221.

112. See HorowITz, supra note 10, at 112-13; Sanjoy Hazarika, India's Assam Cauldron Bubbles Dangerously Again, N.Y. TMES, Dec. 2, 1982, at A2; Nilova Roy, Gandhi's Party Losing in Divided Assam, WASH. POST, Dec. 18, 1985, at A20; Ashutosh Varshney, After the Assam Killings, CHRISTIAN SCI. MONITOR, Mar. 22, 1983, at 27.

113. Since Vasco da Gama's time, Indians have dominated the economies of Kenya, Tanzania, Uganda, and other East African countries. See MANGAT, supra note 95, at 1-9, 21-23, 63-96; H.S. MORRIS, THE INDIANS IN UGANDA 139-40 (1968); David Himbara, The Failed Africanization of Commerce and Industry in Kenya, 22 WORLD DEV. 469, 470-71 \& tbl.1 (1994). Similarly, since French colonial rule, the Lebanese have dominated many of the local economies of West Africa. See Neil O. Leighton, Lebanese Emigration: Its Effect on the Political Economy of Sierra Leone, in THE LEBANESE IN THE WORLD, supra note 95, at 579, 598-99; R. Bayley Winder, The Lebanese in West Africa, in IMMIGRANTS AND ASSOCLATIONS 103, 105, 110-13 (L.A. Fallers ed., 1967). Today, for example, the Lebanese dominate Sierra Leone's diamond, 
with economically dominant African minorities, ${ }^{114}$ and in the Caribbean and the West Indies. ${ }^{115}$ Latin America presents a slightly more complicated picture. ${ }^{116}$ Although the social hierarchy in Latin America is usually thought of in class terms, sociologists long have observed the existence of a "pigmentocracy": that is, a social spectrum with taller, lighter-skinned, Spanish-blooded aristocrats at one end, shorter, darker, Indian-blooded masses at the other end, and a great deal of "passing" in between. ${ }^{117}$ Thus,

gold, finance, construction, real estate, and retail industries and "control access to much international capital in their role as agents and brokers." Leighton, supra, at 600 .

114. The tendency of some African ethnic groups to dominate over others economically can be seen at both the regional and national levels. For example, throughout northern Nigeria, members of the Ibo minority historically dominated the local urban economies. See Robert Melson \& Howard Wolpe, Modernization and the Politics of Communalism: A Theoretical Perspective, in NIGERIA: MODERNIZATION AND THE POLITICS OF COMMUNALISM 1, 8-9 (Robert Melson \& Howard Wolpe eds., 1971). In Uganda, the Baganda dominated economically over the rest of the country even before the British employed them to help rule the country. See HOROWTZ, supra note 10, at 163-64; MAHMOOD MAMDAMI, POLITICS AND CLASS FORMATION IN UGANDA 29-34, 41-44, 120-22 (1976); Bill Berkeley, An African Success Story? (Uganda), ATLANTIC MONTHLY, Sept. 1994, at 22. In Kenya, the Kikuyu historically constituted (together with the Indians) most of the country's elite capitalist class. See Michael Chege, The Political Economy of Agrarian Change in Central Kenya, in THE POLITCAL ECONOMY OF KENYA 93, 9899 (Michael G. Schatzberg ed., 1987); Himbara, supra note 113, at 476. In Rwanda, the Tutsi minority was the economic elite vis-aे-vis the Hutu majority during Belgian colonial rule, and possibly much earlier. See GÉRARD PRUNIER, THE RWANDA CRISIS: HISTORY OF A GENOCIDE 26-45 (1995). The widespread perception that Tutsis were "always" economically dominant may reflect "cultural mythology" rather than historical fact. Id. at 40; see also RENÉ LEMARCHAND, BURUNDI: ETHNOCIDE AS DisCOURSE AND PRACTICE 164 (1994) (discussing the "taboo" issue of Tutsi economic dominance in Burundi).

115. In the Dominican Republic, Haiti, Jamaica, and Trinidad, the Lebanese minority tended to prosper disproportionately when "left alone to make money" and continue today to dominate these countries' commercial and industrial spheres. David Nicholls, Lebanese of the Antilles: Haiti, Dominican Republic, Jamaica, and Trinidad, in THE LEBANESE IN THE WORLD, supra note 95 , at $339,351-54,359$. In Guyana and Trinidad, Indians originally brought over to labor in sugar plantations generally outperform their Creole counterparts in trade and commerce despite repeated backlashes. See VASI, supra note 101, at 237-38, 248-52. In Fiji, the professional and commercial dominance of the Indian (and to a lesser extent, the Chinese) vis-a-vis the indigenous Fijians is "staggering." Id. at 196; see also id. at 196-97 tbls.7-9 (citing wealth and income statistics compiled by the Fijian government).

116. In contrast to Southeast Asia and Africa, intermarriage among ethnic groups (as well as concubinage and polygamy) has been common in Latin America since the colonial era. See MAGNUS MÖRNER, RACE MIXTURE IN THE HISTORY OF LATIN AMERICA 25-26 (1967); Chua, supra note 18, at 271-72. Indeed, perhaps "[n]o part of the world has ever witnessed such a gigantic mixing of races ..." MÖRNER, supra, at 1 .

117. Throughout Spanish America, the so-called sociedad de castas

was created by transferring to the New World the hierarchic, estate-based corporative society of late medieval Castile and imposing that society upon a multiracial, colonial situation. This colonial reality was characterized, first, by the dichotomy between conquerors and conquered, masters and servants or slaves, and, second, by miscegenation between these opposite groups. Hence it was inevitable that social stratification and social status would become closely related to the division into ethnic groups. The location of the existing ethnic groups within the hierarchic social structure gave rise to what a Chilean student has ingeniously called "pigmentocracy." People were classified in accordance with the color of their skin, with the white masters occupying the highest stratum. 
as I have argued elsewhere, the phenomenon of an economically dominant, ethnically distinguishable minority - here, the white, landowning, Westerneducated elite-is an important feature of many Latin American societies. ${ }^{118}$

Central Asia is another developing region in which at least one ethnic minority historically has been economically dominant vis-à-vis the indigenous majority around them. In the vast region that today includes the post-Soviet republics of Kazakhstan, Kyrgyzstan, Tajikistan, Turkmenistan, and Uzbekistan, large waves of Russians (and to a lesser extent Germans and Ukranians) arrived "either in the late tsarist period, in the 1920s and 1930 s, or during the Virgin Lands period under Khrushchev." 119 For reasons including tsarist-era repression of the Central Asian "halfsavages," ${ }^{120}$ Soviet economic policies that were "ostensibly internationalist, but evidently Russocentric," ${ }^{121}$ and different cultural predispositions, ${ }^{122}$ the

MÖRNER, supra note 116, at 54 (citations omitted) (emphasis added); see also MARVIN HARRIS, PATTERNS OF RACE IN THE AMERICAS 38 (1964) (noting that in most Latin American societies "Caucasoid" features were historically "preferred by all strata of the dominant caste; hence the more Indian-looking the less desirable the mestizo type").

118. See Chua, supra note 18, at 271-79. This phenomenon in Latin America is quite stark in countries with significant Indian populations-for example, Bolivia, Mexico, Peru, and most Central American countries-and much more muted in relatively "Europeanized" countries such as Argentina, Chile, and Venezuela, which have smaller (and in some cases, negligible) Indian populations and which saw "enormous waves" of immigrants from Europe early this century. MöRNER, supra note 116, at 133-34; see HARRIS, supra note 117, at 97-98; Chua, supra note 18, at $277-78$.

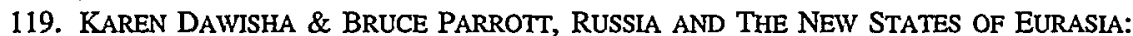
THE POLITICS OF UPHEAVAL 81 (1994); see Martha Brill Olcott, Nation Building and Ethnicity in the Foreign Policies of the New Central Asian States, in NATIONAL IDENTITY AND ETHNICITY IN RUSSIA AND THE NEW STATES OF EURASIA 209, 213 (Roman Szporluk ed., 1994) [hereinafter NATIONAL IDENTITY AND ETHNICITY] (noting that Soviet authorities deliberately encouraged the immigration of ethnic Russians and other non-Asians to Central Asia in order to slow the rise of local nationalism).

120. MARTHA BRILl OlcotT, ThE KazaKHS 51, 58-69, 75, 90, 110 (1987); see also CENTRAL ASIA 170 (Edward Allworth ed., 3d ed. 1994) (quoting tsarist official on Russia's "civilizing role in Central Asia").

121. Ronald Suny, State, Civil Society, and Ethnic Cultural Consolidation in the USSRRoots of the National Question, in FROM UNION TO COMMONWEALTH 22, 27 (Gail W. Lapidus et al. eds., 1992). Soviet policies often favored the needs of the "center" (Moscow) above those of the "periphery" and the interests of local Russian minorities over those of the titular majorities. See OLCOTT, supra note 120, at 248. Thus, Moscow's policy was to use resource-rich Central Asia

as a kind of contiguous Third World that mined and grew raw materials but did not process them. Although Uzbekistan, Kazakhstan, and, to a lesser extent, Kyrgyzstan all had industrial sectors, these tended to be extraction industries rather than manufacturing ones. They also remained overwhelmingly in Russian and European hands, particularly at the administrative level.

Olcott, supra note 119, at 213.

122. Many of the Central Asian peoples were historically nomadic, such as the Kazakhs, the Kyrgyz, and Turkmens. See, e.g., CENTRAL ASIA, supra note 120, at 10, 47. Other Central Asian tribes had sedentary cultures:

The Uzbeks, together with the urban Tajiks, are heirs of the ancient sedentary civilization of the mixed Turkic-Iranian population known before the revolution as "Sarts." Oasis cities of present-day Uzbekistan like Samarkand and 
Russian-speaking minorities in Central Asia dominated the most advanced, prestigious, and lucrative sectors of the economy for two centuries. ${ }^{123}$

Today, despite accelerating rates of Russian emigration after 1989, Russians constitute roughly thirty-seven percent of the population in Kazakhstan; twenty-one percent in Kyrgyzstan, nine percent in Turkmenistan, and eight percent in Uzbekistan. ${ }^{124}$ As elsewhere in the former Soviet Union, the Russian minorities in Central Asia remain predominantly urban, not just at the republic level but also in all subordinate territorial units. ${ }^{125}$ Moreover, in many of the Central Asian republics, Russians still predominate in communications, construction, engineering, electronics, industry, science, transportation, and the new information-computing services sector. ${ }^{126}$ Nevertheless, whether the historical economic dominance of the Russian minorities in Central Asia will persist under the new, post-Soviet regimes is highly questionable and will be discussed specifically in the context of Kazakhstan in Part V. ${ }^{127}$

Bukhara .... became an integral part of the burgeoning Islamic civilization that extended from India in the east to North Africa and Spain to the west.

James Critchlow, The Ethnic Factor in Central Asian Foreign Policy, in NATIONAL IDENTTTY AND ETHNICITY, supra note 119, at 266, 274.

123. See CENTRAL ASIA, supra note 120, at 164, 169, 180-81; JAMES CRITCHLOW, NATIONALISM IN UZBEKISTAN 113-15 (1991); MICHAEL PAUL SACKS, WORK AND EQUALITY IN SOVIET SOCIETY 55-60 (1982); Robert J. Kaiser, Ethnic Demography and Interstate Relations in Central Asia, in NATIONAL IDENTTTY AND ETHNICITY, supra note 119, at 230, 232, 238-39 [hereinafter Kaiser, Ethnic Demography]. Although some Central Asian civilizations achieved grandeur before Russia, illiteracy rates were extremely high and urbanization rates extremely low among the Central Asian peoples until the late 1920s, when Stalin began cultivating indigenous elites under korenizatsiia. See OLCOTT, supra note 120, at 193-96, 206; Robert J. Kaiser, Nationalizing the Work Force: Ethnic Restratification in the Newly Independent States, 36 POSTSOVIET GEOGRAPHY 87, 88 (1995) [hereinafter Kaiser, Nationalizing the Work Force].

124. See Chauncy D. Harris, The New Russian Minorities: A Statistical Overview, 34 POSTSOVIET GEOGRAPHY 1, 4-6 tbl.1 (1993). These figures are from the Soviet Union's 1989 census.

125. See YurTY KulChIK ET AL., Central ASIA AFTER tHE EMPIRE 20-22 (1996). Among Russians, 77\% are urban dwellers in Kazakhstan, 70\% in Kyrgyzstan, and up to $94 \%-97 \%$ in Turkmenistan and Uzbekistan. See id. at 16.

126. See VALERY TISHKOV, ETHNICITY, NATIONALISM AND CONFLICT IN AND AFTER THE SOVIET UNION 121-22, 125 (1997); Kaiser, Nationalizing the Work Force, supra note 123, at 94, 95 tbl.4, 103 tbl.9.

127. Throughout Central Asia, the Uzbeks, who form a significant minority in most of the other Central Asian countries, see DAWISHA \& PARROTT, supra note 119, at 85-86; Kaiser, Ethnic Demography, supra note 123, at 256-58, have tended to be more prosperous than the majorities around them. See, e.g., JEFF CHINN \& ROBERT KAISER, RUSSIANS AS THE NEW MINORITY 229 (1996) (noting that Uzbeks in the Osh Oblast were "an economically privileged group locally"); Eugene Huskey, Kyrgyzstan: The Politics of Demographic and Economic Frustration, in NEW STATES, NEW POLITICS: BUILDING THE POST-SOVIET NATIONS 654, 661 (Ian Bremmer \& Ray Taras eds., 1997) (explaining that in contemporary Kyrgyzstan, for example, Uzbeks in the Osh region are far wealthier than the Kyrgyz, and as of 1990 "controlled, according to one estimate, 80 percent of the city's trade"). See generally Margaret Shapiro, Kirgizstan: New Freedom amid Poverty, WASH. POST, Apr. 4, 1992, at A17 (describing economic conditions and reform measures in Kyrgyzstan). Meanwhile, in Uzbekistan, the Crimean Tartar and Meskhetian Turkish minorities have historically been disproportionately prosperous vis-à-vis the Uzbek majority. See Christie Davies, Politics of Envy Taking Root in Ex-Soviet States, STRAITS TMES (Singapore), Nov. 16, 1992, at 22. Finally, the relatively small Korean minorities in many Central Asian 


\section{B. Ethnoeconomics in the Developed World}

The prevalence and visibility of economically dominant minorities in developing countries starkly distinguishes the problems of ethnic conflict in the developing and developed worlds. While some ethnic minorities in the United States have outperformed other ethnic minorities ${ }^{128}$-and by some measures have outperformed the "white" majority ${ }^{129}$ - the U.S. economy is not dominated by any ethnic minority. ${ }^{130}$ On the contrary, the core ethnic problem in the United States is one that pits an economically and politically dominant white majority against economically and politically weaker ethnic minorities. ${ }^{131}$ As a result, democracy poses no radical threat to an economically dominant ethnic group in the United States. ${ }^{132}$ The same is true throughout the industrialized West. ${ }^{133}$

countries also have tended to be more entrepreneurial and more economically successful than the indigenous majorities around them. See id.

128. See, e.g., David Brand, The New Whiz Kids: Why Asian Americans Are Doing So Well, and What It Costs Them, TnIE, Aug. 31, 1987, at 42; Benjamin Pimentel, Asian Americans: The New Racial Bourgeoisie?, INTER PRESS SERV., Oct. 5, 1995, available in LEXIS, News Library, INPRES File.

129. As of 1995 , the median household income in the United States was $\$ 32,960$ for whites, $\$ 19,533$ for blacks, $\$ 22,8 \$ 6$ for Hispanics, and $\$ 38,347$ for Asian/Pacific Islanders. See BUREAU OF THE CENSUS, U.S. DEP'T OF COMMERCE, STATISTICAL ABSTRACT OF THE UNITED STATES: 1995, at 472 (1995). The percentages of households in the above categories with monetary incomes exceeding $\$ 100,000$ are $6.3 \%, 1.9 \%, 2.3 \%$, and $9 \%$, respectively. See id.

130. See id. As I have already noted, there is a certain artificiality inherent in the ethnic categories generally accepted in the United States. See supra note 11 and accompanying text.

131. See Erik Hurst et al., The Wealth Dynamics of American Families, 1984-94, in 1 BROOKINGS PAPERS ON ECONOMIC ACTIVITY 267, 293, 295 fig.3, 306-09, 307 tbl.19, 308 tbl.20 (1998); see also MELVIN L. OLIVER \& ThOMAS M. SHAPIRO, BLACK WEALTH/WHITE WEALTH: A NEW PERSPECTIVE ON RACIAL INEQUAIITY 1-2, 5,7 (1995) (focusing on wealth rather than income to demonstrate that "whites and blacks constitute two nations" with blacks forming "the sediment of the American stratificational order").

132. As has long been observed, democracy is always in a sense potentially inimical to the interests of a wealthy minority. Thus, David Ricardo was willing to extend suffrage only "to that part of [the people] which cannot be supposed to have an interest in overturning the right of property." STEFAN CollinI ET AL., THAT NOBLE SCIENCE OF POLITICS 107 (1983) (citation omitted). Similarly, for Marx "private property and universal suffrage [were] incompatible." Adam Przeworski, The Neoliberal Fallacy, in CAPITALISM, SOCIALISM, AND DEMOCRACY REVISITED, supra note 17, at 39, 47 (citation omitted). In fact, however, in developed countries such as the United States and the countries of Western Europe, democracy has not proved a radical threat to markets. On the contrary, democracy throughout the industrialized West generally has coexisted robustly with markets, though qualified, to be sure, by redistributive institutions such as progressive taxation and social welfare. See Geoffrey Garrett, Global Markets and National Politics: Collision Course or Virtuous Circle?, 52 INT'L ORG. (forthcoming Fall 1998) (manuscript at 31, on file with The Yale Law Journal) (concluding that in the OECD countries the coupling of global markets with domestic spending and wealth redistribution has proved a stable, "robust and desirable solution"); Przeworski, supra, at 47-48 (noting that "[t]here are 14 countries in the world today that have remained continuously capitalist and democratic for the past half-century").

133. Because the categories employed in statistical research vary by country, the ethnoeconomic status of minority groups across Western countries resists direct comparison. For example, the United Kingdom tends to draw classifications along racial lines, whereas other European countries focus on the national origins of their immigrants. See STEPHEN CASTLES, 
Likewise, and in striking contrast to Southeast Asia, economically dominant ethnic minorities do not exist in the more economically developed societies of East Asia. In each of the "Asian Tigers," the ethnic majoritythe Japanese in Japan, the Koreans in South Korea, and the Chinese in Hong Kong, Taiwan, and Singapore-is economically and politically dominant. ${ }^{134}$ The same is true of China where the Han majority (which constitutes ninety-five percent of the population ${ }^{135}$ ) has dominated economically and politically over ethnic minorities like the Tibetans, Uighurs, and Miao for three millennia. ${ }^{136}$

HERE FOR GOOD: WESTERN EUROPE'S NEW ETHNIC MINORITIES 99 (1984) (comparing Britain's identification of racial minorities with West Germany's focus on "foreigner" status). Nonetheless, a general pattern of lower economic status for ethnic minorities vis-à-vis the ethnic majority is evident throughout the industrialized Western countries. In Canada, mean earnings are significantly lower for ethnic and aboriginal minorities than for whites. See KRISHNA PENDAKUR \& Ravi PENDakur, The Colour of Money: Earnings DifFerentials AMONG EthniC GROUPS IN CANADA 2-4, 7-8, 26 (Research on Immigration and Integration in the Metropolis Working Paper No. 96-03, 1996). In the United Kingdom, ethnic minorities are overrepresented in the lower income brackets. See Department of Social Security: Households Below Average Income Statistics Published, M2 PRESSWIRE, Nov. 18, 1996, available in LEXIS, News Library, M2PW File (citation omitted). In 1995, whites in the United Kingdom constituted 97\% of the top income quintile. See id. By contrast, nearly two-thirds of Pakistanis and Bangladeshis were in the bottom quintile. See id. Throughout Western Europe, the great majority of ethnic minorities and immigrants are either unemployed or employed in the unskilled manual labor sector. See STEPHEN CASTles \& MARK J. Miller, The AGE OF Migration 182, 195-218 (1993); PETER STALKER, THE WORK OF STRANGERS: A SURVEY OF INTERNATIONAL LABOUR MIGRATION 95 (1994).

134. In Singapore, the Chinese constitute roughly $77 \%$ of the population, see 2 THE EUROPA WORLD YEARBOOK 2903 (38th ed. 1997) (citing Singapore's 1990 census), and are an economically, politically, and culturally dominant majority vis-à-vis the country's Indian and Malaysian minorities, see JOSEPH B. TAMNEY, THE STRUGGLE OVER SNGAPORE'S SOUL 20, $96-$ 103, 187 (1996). In Japan and Korea, ethnic minorities are not merely economically disadvantaged, but practically nonexistent. See 1996 Britannica World Data, in ENCYCLOPEDIA BRITANNICA, 1996 BRITANNICA BOOK OF THE YEAR 638, 646 (Glenn M. Edwards ed., 1996). In fact, it was only in 1997 that the Japanese formally acknowledged the existence of an indigenous ethnic minority, the Ainu. See Japanese Parliament Passes 'Ainu' Minority Rights Bill, AGENCE FR.-PRESSE, May 8, 1997, available in LEXIS, News Library, AFP File. In Hong Kong, the English and Chinese are both prosperous, but the numeric strength of the latter (who constitute $99.99 \%$ of the population, $c f$. WORLD ALMANAC AND BOOK OF FACTS, supra note 100, at 753), makes them the economically dominant group. See Angelica Cheung, Hong Kong Handover, THE INDEPENDENT (London), July 1, 1997, at 18. In Taiwan, Han Chinese (including both the Taiwanese Chinese and the Mainland Chinese) constitute roughly $99 \%$ of the population, with non-Han aborgines (yuan-chu min) composing the other one percent. Even if the Taiwanese (roughly $85 \%$ of the population) and the Mainlanders (14\%) were viewed as distinct ethnic groups, the Mainlander "minority" is not economically dominant. See ALAN WACHMAN, TAIWAN: NATIONAL IDENTITY AND DEMOCRATIZATION 16-17 (1994).

135. See JOHN KING FAIRBANK, CHINA: A NEw HISTORY 23 (1992) (noting that over one billion Chinese trace their ancestry to the Han dynasty). This general statistic hides the fact that ethnic minorities represent a majority in autonomous regions such as Tibet and Xinjiang. See THOMAS HEBERER, CHINA AND ITS NATIONAL MiNORITIES 93-94, 100 tbl.6.18 (1989) (showing that as of 1987 non-Han groups made up $95.4 \%$ and $61.4 \%$ of the total population of Tibet and Xinjiang, respectively).

136. See, e.g., HEBERER, supra note 135 , at 19 (noting that although some non-Han peoples did subjugate the Han and establish their own dynasties, "it was primarily the Han who subjugated the other peoples and exacted tributes from them"). For the purposes of this Article, I will assume, along with most Sinologists, that the "Han" Chinese may be viewed appropriately as 


\section{Economic Dominance and Market Dominance}

Why some ethnic groups dominate economically over others is a formidable topic that this Article cannot possibly address adequately. Although it is fashionable in some circles to attribute superior group economic performance primarily to genetics, ${ }^{137}$ the reasons for economic dominance clearly vary from context to context, and explanations taking account of historical and cultural factors show a far greater breadth of understanding. ${ }^{138}$ In any event, for purposes of this Article, the crucial question is whether a particular ethnic group in a particular country is market-dominant.

Not every economically dominant minority is a market-dominant minority. Some groups-such as Russians in Central Asia (and elsewhere in the former Soviet Union), Afrikaners in South Africa, and Spaniards in Latin America-originally installed themselves as colonizers, using military force and the powers of the state to ensure their own economic and political dominance over subordinate majorities. ${ }^{139}$ To the extent that these groups owe their economic dominance solely or principally to nonmarket factors, their historical economic dominance may not persist under competitive market conditions. On the contrary, marketization may dissipate their economic dominance by opening up opportunities to disadvantaged groups previously prevented from participating fully in the economy.

On the other hand, it is possible that decades of political control by an ethnic minority may itself give rise to market dominance. In South Africa, for example, whites today almost certainly are market-dominant (at least in the near to midterm future), but surely this is in significant part because they have relegated the black majority to inferior educational opportunities and generally inhumane conditions for the past fifty years. ${ }^{140}$

a single ethnic group. See, e.g., JACQUES GERNET, A HISTORY OF CHINESE CIVILIZATION 13 (J.R. Forster trans., Cambridge Univ. Press 1982) (1972); HEBERER, supra note 135, at 10-12. This is not to deny important differences within China along provincial, north-south, and rural-urban lines. See China Wants Foreign Banks to Boost Lagging Regions, REUTERS FIN. SERV., Jan. 4, 1997, available in LEXIS, News Library, WIRES File; Deepening Regional Disparities Threaten Chinese Renaissance, ASIA TIMES, Dec. 28, 1995, at 5.

137. In a recent, controversial book, Richard Herrnstein and Charles Murray argue that cognitive ability differs across ethnic groups, see RICHARD HERRNSTEIN \& CHARLES MURRAY, THE BELL CURVE (1994), that these differences are inheritable and attributable in significant part to genetics, see id. at 299-312, and that poverty in the United States is concentrated among those with low I.Q.s, see id. at 371.

138. See, e.g., Claude S. Fischer ET AL., INEQUALITY BY DESIGN: CRACKING the Bell CURVE MYTH (1996). (1994).

139. See TED ROBERT GURR \& BARBARA HARFF, ETHNIC CONFLICT IN WORLD POLITICS 24

140. South Africa is discussed in greater detail infra Section V.A. 
The form of economic dominance in the developing world most likely to indicate market dominance is that of noncolonizer, "entrepreneurial" minorities such as the Chinese, Indians, and Lebanese. ${ }^{141}$ It is often said that these "middleman" minorities are "culturally" predisposed to entrepreneurial success as a result of group differences in work habits, savings propensities, or attitudes toward education and commerce. ${ }^{142}$ Thus the Chinese in Southeast Asia (and elsewhere) are said to be driven by an "intense profit motive" relatively absent among Malays and Filipinos; ${ }^{143}$ the Vietnamese are "frugal," "industrious," and "inventive" compared to the supposedly more artistically oriented Cambodians; ${ }^{144}$ Indians in the Caribbean and throughout East Africa operate on tiny profit margins, live extremely cheaply, and are felt to be "single-mindedly devoted to work and accumulation." 145 Relatedly, a good deal of recent scholarship explains the success of Chinese, Indian, Korean, and Lebanese communities in terms of their solidarity and "social networking," in contrast to the Thai, who, for example, "don't trust one another" and "relate to one another only in a hierarchical way." 146 On this view, marketization in the developing world

141. As Professor Sowell has explained, "In one way or another, middlemen facilitate the movement of goods from the producer to the consumer, without necessarily physically producing anything themselves." SOWELL, supra note 97, at 27. Examples "include retailers, ranging from pushcart peddlers to international merchants, and money-lenders, ranging from pawnbrokers and petty loan sharks to international financiers." $I d$.

142. Since Max Weber's classic essay, The Protestant Ethic and the Spirit of Capitalism, many social scientists have explored the relationship between cultural attitudes and economic success. Thus, in the 1950s, "Weber's Protestant Ethic [was] modemized into David McClelland's 'achievement motivation' as a precondition of progress and into Edward $\mathrm{C}$. Banfield's 'amoral familism' as an obstacle." ALBERT O. HIRSCHMAN, RIVAL VIEwS OF MARKET SOCIETY 19 (1992). More recently, Thomas Sowell and others have observed that "[c]ultural attitudes toward commerce and industry have varied as much as attitudes toward education." SowELL, supra note 95, at 25. Professor Sowell also has noted elsewhere that "there must be some cultural difference between the middlemen and those they serve. Otherwise, each community or nation would supply its own middlemen." SOWELL, supra note 97 , at 27.

143. Phuwadol Songprasert, The Economic Roles, Positions and Problems of the Chinese and the Malay Muslims in the Thai Polity: A Comparative Study, in ECONOMIC DIMENSIONS OF ETHNIC CONFLICT 119, 128 (S.W.R. de A. Samarasinghe \& Reed Coughlan eds., 1991); see also SOWELL, supra note 97, at 191-92, 207.

144. See HENRY KAMM, DRAGON AsCending: VIETNAM AND THE VIETNAMESE 24 (1996); Chou Meng Tarr, supra note 107 , at 35 . "Cambodians felt that they were culturally superior to the Vietnamese, particularly in the fields of art, craft, literature and music" and in Khmer language dismissed the Vietnamese "as lacking the capacity for the finer experiences of life." Id.

145. HorowITZ, supra note 10, at 170; see also SowELL, supra note 97 , at 318 . Cultural distinctions have been drawn in Eastern Europe as well. The Estonians and Latvians, for example, are said to be especially hardworking (relative to Russians) because of their "Protestant work ethic." Walter C. Clemens, Jr., Baltic Identities in the 1990s: Renewed Fitness, in NAMONAL IDENTITY AND ETHNICITY, supra note 119, at 185, 190.

146. LaWrence E. Harrison, Who PRospers? How Cultural Values SHaPe ECONOMIC AND POLITICAL SUCCESS 15 (1992); $c f$. JACQUES AMYOT, THE CHINESE AND THE NATIONAL INTEGRATION IN SOUTHEAST ASIA 80-81 (1972) (suggesting that the economic power of the Chinese in Thailand stems in large part from cohesive kinship ties and complex patterns of community associations); KOTKIN, supra note 99, at 206 (noting that the Sindhi diaspora "tends to "cling together" while Jain diamond merchants "are very close and everyone knows 
almost certainly would be expected to further the economic dominance of these hardworking, capital-saving, "more cohesive and well organized" entrepreneurial groups. ${ }^{147}$

This conclusion, however, may overemphasize greatly the economicas opposed to the political-skills or savvy of so-called "entrepreneurial" groups. For example, the tremendous wealth of the Chinese in Southeast Asia may reflect good political connections and a "talent" for getting monopoly privileges from the state as much as superior commercial skills. ${ }^{148}$ At the same time, the success of Indian and Lebanese merchants in many African countries is often attributed to their allegedly corrupt and illicit government connections. ${ }^{149} \mathrm{~A}$ slightly different line of thought suggests that the success of all of these groups lies in the "divide-andconquer" strategies of European colonizers, who ensured that economic control, to the extent that it was not monopolized by the colonizer, lay "with a politically impotent class of pariah [non-native] businessmen." 150 To the extent that these political favoritism accounts are correct, it is by no means guaranteed that the developing world's "entrepreneurial" minorities will continue to enjoy economic dominance under genuine competitive conditions.

Nevertheless, that certain ethnic minorities are better able than others to exploit the economic possibilities of political favoritism may not be fortuitous. If European colonial powers pursued a "divide-and-conquer" strategy in Southeast Asia and Africa, their decision to deal profitably with certain immigrant groups such as the Chinese or Indians surely had something to do with the fact that these groups had dominated trade there

everyone") (citations omitted); id. at 234 (stating that the Koreans have begun to establish "their own powerful global network"); MURRAY WeDENBAUM \& SAMUEL HUGHES, THE BAMBOO NETWORK: How EXPATRIATE CHINESE ENTREPRENEURS ARE CREATING A NEW ECONOMIC SUPERPOWER IN ASIA 3-6, 23-59 (1996) (arguing that the "bamboo network" of expatriate Chinese family-oriented enterprises accounts for Chinese economic dominance).

147. HOROWITZ, supra note 10 , at 170.

148. See INGRAM, supra note 98, at 20 (noting that the economic "supremacy" of the Thai Chinese reflected in part the government practice of granting them trade monopolies). I discuss this possibility below more fully in the context of Vietnam. See infra Subsection V.C.3.b.; $c f$. PAUL KENNEDY, AFRICAN CAPITALISM: THE STRUGGLE FOR ASCENDANCY 71-72 (1988) (noting that in Uganda, officials in the Obote regime granted trade monopolies to prominent Indian businessmen in exchange for lucrative directorship positions); Himbara, supra note 113, at 477 (noting that in Kenya in the 1970s "the most successful Kikuyu capitalists were notables in President Kenyatta's own family or in key state institutions").

149. See, e.g., Didier Bigo, The Lebanese Community in the Ivory Coast: A Non-native Network at the Heart of Power?, in THE LEBANESE IN THE WORLD, supra note 95, at 509, 50910; Greg Barrow, Kenyan Asians Fight Back as Politicians Call for Expulsion, GUARDIAN (London), June 19, 1996, at 13.

150. BENEDICT ANDERSON, IMAGINED COMMUNITIES 116 (rev. ed. 1991); see, e.g., Philip Gourevitch, The Poisoned Country, N.Y. REv. BooKs, June 6, 1996, at 59, 60 (stating that in Rwanda and Burundi the Belgians pursued a policy of divide-and-conquer that favored Tutsis over Hutus for educational, professional, and political opportunities). 
long before the European colonizers arrived on the scene. ${ }^{151}$ Hence, the political favoritism explanation ultimately may beg the question and return the inquiry to cultural factors.

But cultural explanations also beg a more difficult question: Why do certain ethnic groups develop commercially advantageous cultural traits? Weber famously pointed to political exclusion as a potential explanation, noting that minorities excluded from positions of political influence "were driven with peculiar force into economic activity." 152 More recently, rational choice theorists have attributed the economic success of certain "ethnically homogeneous middlemen groups" to the small size and social connectedness of these groups, which "give their members a unique means of (informally) sanctioning contract breaches by other group members." 153

It is not obvious whether these further explanations are sufficient. Numerous politically excluded minorities do not attain economic success. Likewise, there are plenty of numerically small ethnic groups that have not become successful middlemen. ${ }^{154}$ Resolving these issues is not necessary

151. In pre-colonial Indonesia, for example,

all foreign trade in the [Tabanan] kingdom-the main export was coffee, the main import opium-was conducted by a single wealthy Chinese called a subandar, who held a royal monopoly in exchange for a suitable tribute, the remainder of the small resident Chinese population acting as his agents. Domestic trade was trifling ....

GEERTZ, supra note 95, at 25-26. Of course, this observation may be owing to Chinese imperialism in Southeast Asia, which antedates Western colonialism. See CHARLES O. HUCKER, CHINA'S IMPERIAL PAST 1 (1975). Similarly, in East Africa, Indian merchants as early as the second century A.D. functioned as "the principal suppliers of cotton cloth, beads, and sundry manufactured articles and as importers of ivory, gold, iron, gum copal, ambergris, incense." MANGAT, supra note 95 , at 1 .

152. MAX Weber, THE PRotestant ETHIC AND the SPIRIT OF CAPITALISM 39 (Talcott Parsons, Routledge 1992) (1930). Weber specifically had in mind Poles in Russia and Eastern Prussia, Huguenots in France, Nonconformists and Quakers in England, and Jews generally. See id.

153. Richard H. McAdams, The Origin, Development, and Regulation of Norms, 96 MrCH. L. REv. 338, 343 (1997) (footnote omitted); see Robert Cooter \& Janet T. Landa, Personal Versus Impersonal Trade: The Size of Trading Groups and Contract Law, 4 INT'L REV. L. \& ECON. 15 (1984); Sumner J. La Croix, Homogeneous Middleman Groups: What Determines the Homogeneity?, 5 J.L. ECON. \& ORG. 211, 219 (1989); Janet T. Landa, A Theory of the Ethnically Homogeneous Middleman Group: An Institutional Alternative to Contract Law, 10 J. LEGAL STUD. 349, 355-57 (1981); see also Lisa Bernstein, Opting out of the Legal System: Extralegal Contractual Relations in the Diamond Industry, 21 J. LEGAL STUD. 115, 140-41 (1992) (explaining that in the diamond industry, which historically has been dominated by Orthodox Jews, most intra-industry disputes generally are resolved without recourse to the legal system); Robert C. Ellickson, A Hypothesis of Wealth-Maximizing Norms: Evidence from the Whaling Industry, 5 J.L. ECON. \& ORG. 83, 84 (1989) (exploring the "hypothesis that when people are situated in a close-knit group, they will tend to develop for the ordinary run of problems norms that are wealth-maximizing").

154. Indeed, it has been suggested that too high a degree of familial or clannish trust may in some contexts obstruct entrepreneurialism. See GEERTZ, supra note 95, at 131-32; KENNEDY, supra note 148, at 143. Francis Fukuyama argues that familial or clannish trust, while allowing the success of small, individual businesses, is actually an obstacle to economic success at the national level. See Francis FuKUYAMA, TRUST: THE SOCIAL VIRTUES AND THE CREATION OF PROSPERITY 28-29 (1995). Fukuyama focuses instead on the importance of generalized social 
here. For purposes of the model proposed in Part IV, the crucial question is whether the economic dominance of a given ethnic minority will tend to persist or even increase under marketization, no matter what the underlying explanation. ${ }^{155}$

\section{MARKETIZATION, DEMOCRATIZATION, AND ETHNONATIONALISM: A MODEL}

Drawing on historical evidence and a wide-ranging social science literature, this Part proposes a model to explore the consequences of pursuing markets and democracy under the following conditions: (1) economic underdevelopment; (2) severe ethnic divisions; (3) the presence of a market-dominant ethnic minority; and (4) the presence of an impoverished majority with claims to being the "true owners of the nation" (often by virtue of their supposed "indigenousness"). Section A below gives an overview of the model. Section $B$ addresses the prevalence of the model conditions in the developing world. Section $\mathrm{C}$ discusses the outcomes predicted by the model if marketization and democratization are pursued in countries satisfying the model conditions and demonstrates that these outcomes are corroborated by historical evidence from throughout the developing world. Section D considers possible counterexamplescountries arguably satisfying the model conditions where markets and democracy have not produced the model outcomes-and notes certain factors that might complicate the model's application in real-world cases. Finally, Section E highlights some general policy implications of the model, preparing the way for the model applications in Part V.

\section{A. Overview}

Suppose country $X$ satisfies the model conditions. Suppose that the population of country $X$ consists of two rival ethnic groups: a relatively impoverished ethnic majority (the $M s$ ) and a market-dominant ethnic minority (the $M D M s$ ). Suppose, finally, that country $X$ simultaneously pursues marketization and democratization. In these circumstances, three hypotheses can be advanced:

trust, as measured by the presence or absence of large multinational corporations, as a precondition for success in the global economy. See id.

155. In many developing countries, this question may be impossible to answer until marketization is actually in progress. 
I. Notwithstanding possible slight absolute gains in the $M \mathrm{~s}^{\prime}$ economic position as a result of marketization, ${ }^{156}$ the $M D M \mathrm{~s}^{\prime}$ economic dominance, coupled with the $M$ s' continuing pervasive poverty, will provoke, maintain, or exacerbate intense ethnoeconomic resentment among the disadvantaged $M$ s.

II. With democratization, this ethnoeconomic resentment among the $M \mathrm{~s}$ will tend to be mobilized and transformed into a potent ethnonationalist movement dedicated to eliminating the MDMs' economic dominance.

III. As a result, marketization and democratization in country $X$ will be difficult, if not impossible, to sustain simultaneously. If all the model conditions are fully satisfied, powerful pressures will push $X$ toward one or more of three basic outcomes: (1) an ethnically targeted antimarket backlash ${ }^{157}$ (2) actions directed at eliminating the MDMs (e.g., atrocity or expulsion); or (3) a retreat from democracy.

Two points must be made before proceeding. First, in focusing on ethnic division, I am not trying to minimize the importance of class conflict or other potential lines of social division in developing countries. But in the developing world, ethnicity has played a much greater role within class conflict than social theorists generally have recognized. ${ }^{158}$ Moreover, in the last several decades, ethnicity has been a far more fertile source of political mobilization and mass conflict than has either class or religion. ${ }^{159}$

156. If marketization produced tremendous and rapid economic gains among the $M \mathrm{~s}$, then $X$ would no longer satisfy model conditions one (economic underdevelopment) and four (presence of an impoverished majority). This happy but extremely unlikely possibility is discussed further below. See infra text accompanying notes 204-205.

157. As discussed further below, by "antimarket backlash" I am not referring to after-market redistributions, such as progressive taxation or welfare programs, but rather to ethnically targeted, direct interventions into actual market functions-for example, through ethnically targeted nationalizations or ethnically based restrictions on commercial activity. See infra text accompanying notes $248-275$.

158. The extent to which this is true obviously varies. For example, the role of ethnicity is relatively small in "Europeanized" Latin American countries such as Argentina or Uruguay. The model accounts for such variation through the model conditions.

159. See HOROWITZ, supra note 10, at xi, 105-06 (observing that "[e]thnicity is at the center of politics in country after country" and that "ethnic affiliations generally seem to elicit more passionate loyalty than do class allegiances"); Frye, supra note 33, at 599 (noting that in the attempted transitions to democracy in Czechoslovakia, Spain, the Soviet Union, and Yugoslavia, ethnicity was "politicized to a much greater degree than class or religion"). The interrelationship among ethnicity, religion, and class is complex and beyond the scope of this Article. Suffice it to say here that religion is one of many factors that may shape ethnic identity. See Hettne, supra note 41, at 17. Moreover, "[e]thnicity may overlap with class, in which case the result will be an enforcement of class consciousness. Ethnicity may also cut across class, in which case the effect on class consciousness may be the opposite." Id. at 17. 
Second, neither the model nor the hypotheses depend on any particular theory about why ethnic conflict occurs. ${ }^{160}$ Specifically, I am not arguing that economics in general, or economically dominant minorities in particular, are at the root of ethnic animosity. ${ }^{161}$ Indeed, the model presupposes the presence of severe ethnic divisions. Furthermore, I am not suggesting that democracy is necessary (or more likely than authoritarianism) to trigger an ethnonationalist reaction. Rather, the point of the model is that in developing countries where a market-dominant ethnic minority is present, democracy can proceed only in deep tension with markets. Instead of reinforcing the market's efficiency and wealthproducing effects, democratization in such cases ordinarily will lead to powerful majoritarian, ethnonationalist pressures. If such ethnonationalism becomes sufficiently potent, one or more of the three hypothesized outcomes likely will occur.

\section{B. Definition and Prevalence of Model Conditions}

The model's first condition-economic underdevelopment-occurs in all developing countries by definition. Condition two-severe ethnic divisions-refers to societies where powerful ethnic allegiances and rivalries "permeate organizations, activities, and roles to which they are formally unrelated," 162 and capital, labor, political parties, and many other sectors of social life "are often organized along ethnic lines." ${ }^{163}$ This

160. Just as there are many competing conceptions of ethnicity, see supra note 31 , there are numerous theories of ethnic conflict. Cultural pluralist theories focus on the clash of mutually incompatible values among culturally divergent groups. See, e.g., J.S. FURNIVALL, CoLONIAL POLICY AND PRACTICE 303-12 (1948); M.G. Smith, Institutional and Political Conditions of Pluralism, in PLURALISM IN AFrICA 27, 38, 53-54 (Leo Kuper \& M.G. Smith eds., 1969). By contrast, modemization and economic-interest theories stress group competition over resources and opportunities, often highlighting the role of elites in fomenting conflict. See, e.g., Robert H. Bates, Ethnic Competition and Modernization in Contemporary Africa, 6 COMP. POL. STUD., 457, 457, 468-71 (1974); Bonacich, supra note 95, at 589; Melson \& Wolpe, supra note 114, at 1-10; infra note 211 (discussing different views of ethnic mobilization). Other well known theories of ethnic conflict do not fit into either of these categories. See, e.g., HoRowITZ, supra note 10, at 139-40 (critiquing both the cultural pluralist and modernization and materialist perspectives and advocating a more inclusive theory of ethnic conflict); SMTTH, supra note 10, at 5-6 (proposing "a broad socio-historical approach" to understanding the modern ethnic revival). For an excellent collection of essays analyzing ethnic conflict in developed as well as developing societies, see ETHNICITY: THEORY AND EXPERIENCE, supra note 19.

161. Theories of economic determinism that ascribe all or most ethnic conflict to economic causes generally have been discredited: "To argue, for example, that the Israeli-Palestinian struggle is basically about economic values, or that the Quiet Revolution is mainly about employment opportunities for educated Quebecois ... utterly trivializes and distorts the meaning and stakes of these conflicts." ESMAN, supra note 31, at 234. Nevertheless, "[t]here is likely to be an economic dimension to most ethnic conflicts." Id. at 231.

162. HoROWITZ, supra note 10, at 7-9.

163. Id. This is not to suggest that some societies are "inherently or inevitably divided." Ian Shapiro \& Courtney Jung, South African Democracy Revisited: A Reply to Koelble and Reynolds, 24 POL. \& SOC'Y 237, 243 (1996). On the contrary, ethnic divisions may shift or change over 
definition includes almost all of the postcolonial societies of Africa, Asia, and the Caribbean as well as many countries in Eastern Europe and the former Soviet Union. ${ }^{164}$ Most Latin American countries also satisfy this condition, even though political conflict in the region tends to be "conceptualized mainly in terms of class rather than ethnicity or race." 165

The prevalence of condition three-the presence of a market-dominant ethnic minority-has already been discussed. ${ }^{166}$ It is worth reiterating, however, that not every economically dominant ethnic minority is marketdominant for the purposes of this model. Moreover, market dominance need not be caused by superior entrepreneurialism "built in" to a particular group's genes or culture. Market dominance could, for example, also be the result of decades of political subjugation by an ethnic minority. As we shall see, condition three is a pivotal and often complex variable.

Finally, the vast majority of societies satisfying condition three also meet condition four-that is, the presence of an impoverished majority with claims that they are the "true owners of the nation." ${ }^{167}$ In most of these cases, the disenchanted majority asserts group priority by highlighting its indigenousness. ${ }^{168}$ These claims of majority "indigenousness" are frequently highly artificial and often the product of elite manipulation. In Sri Lanka, for example, the majority Sinhalese regard themselves as "true" Sri Lankans, and the Ceylon Tamils as foreign intruders, even though the latter "arrived, on average, perhaps a thousand years ago, [and] can hardly be regarded as immigrants." ${ }^{169}$ Most of the economically dominant Indians expelled from Burma (now Myanmar) in the 1960s had roots in the country dating back generations. ${ }^{170}$ Similarly, the vast majority of Chinese in Southeast Asia today are citizens of the countries in which they live and are

time. See id.; see also Donald L. Horowitz, Ethnic Identity, in ETHNICITY: THEORY AND EXPERIENCE, supra note 19, at 111, 113 (describing the fluidity of ethnic boundaries).

164. See HIRSCHMAN, supra note 34, at 14; SMITH, supra note 10, at 8-12; Horowitz, supra note 51 , at $18-20$.

165. James D. Fearon \& David D. Laitin, A Cross-Sectional Study of Large-Scale Ethnic Violence in the Post-War Period 16 (Sept. 30, 1997) (unpublished manuscript, on file with The Yale Law Journal); see also Julian Pitt-Rivers, Race, Color, and Class in Central America and the Andes, in 2 READINGS IN LATIN AMERICAN HISTORY 312, 317-18, 321 (John J. Johnson et al. eds., 1985) (describing "the role ethnic distinctiveness plays in ordering the society of Latin America" and noting that "there is no color bar but rather a color scale"). Julian Pitt-Rivers has suggested that the correlation between class and color in Latin America is increasing rather than decreasing. As growing numbers of unassimilated Indians move to the city, "[t]he result is a continual influx of persons of mainly Indian physique into the proletariat. At the same time, the immigration of Europeans into these countries has been very considerable in the last two decades, and these Europeans have almost all been absorbed into the upper classes." Id. at 326.

166. See supra Section III.C.

167. HOROWITZ, supra note 10, at 202, 206, 208; see Horowitz, supra note 51, at 23-25.

168. See Horowitz, supra note 51, at 23-25.

169. HOROWITZ, supra note 10 , at 203.

170. See GOLAY ET AL., supra note 95, at 209; SMITH, supra note 108, at 200-01. 
unlikely ever to return to China. ${ }^{171}$ Nevertheless, such groups are generally treated as outsiders by "indigenous" majorities. ${ }^{172}$

\section{Model Hypotheses}

The basic thrust of the model is that, in countries satisfying the specified conditions, marketization and democratization will tend to benefit different ethnic groups, producing a highly volatile and potentially destructive dynamic along the lines indicated by the three model hypotheses. This Section will substantiate each of these three hypotheses with historical and sociological evidence from the developing world.

\section{Hypothesis I: Ethnoeconomic Resentment Against Market- dominant Minorities}

It is possible that in prosperous societies where everyone is thriving, the fact that market policies favor a certain ethnic minority may not produce serious destabilizing consequences. ${ }^{173}$ In developing countries, however, the situation is starkly different. Although the details differ from country to country, the overall story is remarkably similar. Marketization either causes, maintains, or exacerbates the economic dominance of a particular ethnic minority, and this economic dominance in turn causes, maintains, or exacerbates intense ethnic resentment. The following provides a stylized account:

$\mathrm{X}$ 's leaders have initiated market-oriented economic reforms. ${ }^{174}$ Expectations are high, as these leaders have waxed eloquent about the liberating and wealth-producing promise of the free market. Early results, however, do not deliver on this promise. ${ }^{175}$ Among the $\mathrm{Ms}$, unemployment persists and possibly even increases. Similarly, prices for some basic commodities may actually rise. Most $\mathrm{Ms}$ continue to live in abject conditions. At the same time, the MDMs prosper disproportionately. The Ms may or may not be better off

171. See SoWELL, supra note 97 , at 180.

172. See, e.g., GEERTZ, supra note 95, at 11-12, 77-78; VASI, supra note 101, at 225-26; WaLter F. Vella, Charyo! KING VaJiRavudh AND THE DEVElopMENT OF THAI NATIONALISM 194-95 (1978); Horowitz, supra note 51, at 23-25.

173. In a cross-sectional study of ethnic violence, Fearon and Laitin found that "robust growth in per capita income is strongly associated with a lower probability of large-scale ethnic violence." Fearon \& Laitin, supra note 165 , at 18.

174. Such reforms typically include privatization, liberalization of trade and capital restrictions, and elimination of price controls and state subsidies.

175. In a well known book, Gurr argued that when actual income is less than expected income, people become frustrated, angry, and more disposed to violent conflict. See TED ROBERT GURR, WHY MEN REBEL 9, 12-14, 360-67 (1970); see also Fearon \& Laitin, supra note 165, at 18 (predicting increased conflict whenever income growth is less than anticipated). 
from an absolute perspective, but any sense of improvement is overwhelmed by their continuing poverty and the visible economic dominance of the MDMs. ${ }^{176}$ Frustrated by their relative lack of success, the Ms regard the MDMs as greedy, exploitative, and unscrupulous. As time passes, and the entrenchment of their poverty becomes more palpable, the $\mathrm{Ms}$ ' animosity toward the MDMs may intensify. Ethnic scapegoating, violence, and even rioting are genuine dangers.

For purposes of the model, it makes no difference whether this ethnoeconomic resentment arises "from the bottom up" or results from deliberate manipulation by political elites. ${ }^{177}$ Similarly, it makes no difference whether a minority's disproportionate economic success under market policies intensifies ethnic resentment, merely provides a convenient focus for preexisting animus, or creates severe resentment where none existed before. Regardless of which of these accounts applies in any given case, the phenomenon of deep resentment against economically dominant ethnic minorities has played out in every region of the developing world. For example, throughout Southeast Asia, Chinese entrepreneurial success has provoked the hatred and envy of indigenous majorities since the colonial period. ${ }^{178}$ Time and again, the Chinese-seen as venal,

176. Although often neglected in standard economic modeling, the insight that people's happiness may depend heavily on their relative position vis-à-vis other individuals or other groups has been recognized by leading theorists in a broad range of disciplines. See, e.g., A.C. PIGOU, THE ECONOMICS OF WELFARE 89-90 (4th ed. 1948) (quoting John Stuart Mill) (philosophy); ADAM SMTTH, THE THEORY OF MORAL SENTIMENTS 112-13 (D.D. Raphael \& A.L. Macfie eds., Clarendon Press 1976) (1759) (economics); SAMUEL A. STOUFFER, THE AMERICAN SOLDIER: ADJUSTMENT DURING ARMY LIFE (1949) (sociology); Guido Calabresi, About Law and Economics: A Letter to Ronald Dworkin, 8 HOFSTRA L. REV. 553, 556 (1980) (law); Leon Festinger, A Theory of Social Comparison Processes, 7 HUM. ReL. 117 (1954) (social psychology); Amartya Sen, Poor, Relatively Speaking, 35 OXFORD ECON. PAPERS 153 (1983) (economics). For a discussion of these and other sources, and for an excellent exploration of "the positive and normative implications of relative desires, particularly with respect to law and legal theory," see Richard H. McAdams, Relative Preferences, 102 YALE L.J. 1, 6, 10-11, 31-32 (1992).

177. There is a broad literature discussing the manipulation of ethnic divisions by political elites. See, e.g., JOHN BREULLY, NATIONALISM AND THE STATE 19-22 (2d ed. 1994); ESMAN, supra note 31, at 230-31; GURR \& HARFF, supra note 139, at 78-79, 83-85, 89; CHARLES TIILY, From MOBILIZATION TO REVOLUTION 69-84 (1978); Guyora Binder, The Case for SelfDetermination, 29 STAN. J. INT'L L. 223, 242 (1993); Donald L. Horowitz, Cause and Consequence in Public Policy Theory: Ethnic Policy and System Transformation in Malaysia, 22 PoL. SCI. 249, 255-56 (1989); Edward D. Mansfield \& Jack Snyder, Democratization and War, FOREIGN AFF., May/June 1995, at 87-88; Diane F. Orentlicher, Separation Anxiety: Intemational Responses to Ethno-Separatist Claims, 23 YALE J. INT'L L. 1, 17 \& n.84 (1998). Below, I address such political manipulation specifically in the context of democratizing countries. See infra text accompanying notes 209-211.

178. See, e.g., LYNN PAN, SONS OF THE YELLOW EMPEROR 215 (1990); SOWELL, supra note 97, at 181-213. According to Sowell, large-scale emigration from China into Southeast Asia began only after European colonial powers "consolidated their control in the region in the sixteenth and early seventeenth centuries, and created stable conditions in which Chinese immigrants could feel secure." Id. at 181. 
exploitative, and perverse ${ }^{179}$ - have been portrayed as "draining away the [nation's] wealth" ${ }^{180}$ and posing a "menace to all the principles of economic vitality of the country." 181 Anti-Chinese violence is an integral part of the region's history that continues to this day. ${ }^{182}$ In Indonesia, for example, where roughly six million working age people (almost all Indonesians) are unemployed, ${ }^{183}$ the Chinese are regular targets of arson, vandalism, and ethnic rioting. ${ }^{184}$ Scapegoating of, and retaliation against, Southeast Asia's "greedy" and "hoarding" Chinese "locusts" have visibly intensified as a result of the region's recent financial crisis. ${ }^{185}$

Are there any Southeast Asian countries where economically dominant Chinese have not provoked violent resentment? Singapore is an obvious exception, which also happens to prove the rule, because the Chinese there have been an economically dominant majority since independence. The only other possible negative case is contemporary Thailand, where relations between the economically dominant Chinese minority and the Thai majority appear to be amiable. ${ }^{186}$ Nevertheless, for reasons discussed below, the Thai "exception" may also confirm the rule. ${ }^{187}$

Resentment and vindictive terror have been directed at other economically dominant minorities in Southeast Asia and throughout the developing world. Assamese have repeatedly attacked Bengalis. ${ }^{188}$ Burmans killed thousands of Indians during World War $\amalg{ }^{189}$ More recently, a Tamil (1994).

179. See PAN, supra note 178, at 214-15; ADAM SCHWARTZ, A NATION IN WAITING 103

180. SOWELL, supra note 97 , at 182.

181. AMYOT, supra note 146 , at 32 (quoting from an anti-Chinese report sent from the Philippines to the government of Spain in 1896). Early on, many Chinese immigrants remitted profits back to their families in China. See SowELl, supra note 97, at 182. As Professor Sowell has observed, however, these remittances were tiny in comparison to the wealth generated by the "overseas Chinese" for their host countries' economies. See id.

182. See, e.g., AMYOT, supra note 146, at 26; SowELL, supra note 97, at 195, 203, 205.

183. See Paul Jacob, 6.3 Million Indonesians out of Job Last Year, STRAITS TIMES (SINGAPORE), Nov. 8, 1996, at 18.

184. See Leah Makabenta, Indonesia: Ethnic Chinese Economic Success Fuels Racial Tension, INTER PRESS SvC., Mar. 25, 1993, available in LEXIS, News Library, INPRES File; Seth Mydans, In Indonesia, Spark of Intolerance Lights Fires of Ethnic Rioting, INT'L HERALD TRIB., Apr. 9, 1997, at 1; Peter Waldman, As Good Times Roll, Indonesia's Chinese Fear for Their Future, WaLL ST. J., June 5, 1997, at A18.

185. Michael Sheridan, Bitter Asia Turns on Chinese "Locusts," SUNDAY TMES (London), Feb. 1, 1998, available in LEXIS, News Library, CURNWS File; see also Indonesians Riot: Mobs Blame Chinese for Money Crisis, NEwSDAY, Feb. 14, 1998, at A14. Dozens, possibly hundreds, of Indonesian Chinese were killed in the recent riots that led to President Suharto's resignation. See Richard Borsuk \& Marcus W. Brauchli, Suharto Resigns, and Vice President Takes Over, WaLl ST. J., May 21, 1998, at A8; Uli Schmetzer, Fearful Ethnic Chinese Trying To Flee Indonesia, CHI. TRIB., May 17, 1998, at 4.

186. See Horowitz, supra note 51, at 19; Michael Vatikiotis, Sino Chic, FAR E. ECON. REV., Jan. 11, 1996, at 22; James Fallows, Boom Times in Bangkok, L.A. TIMES, Apr. 10, 1994 (Magazine), at 18.

187. See infra Subsection IV.D.1.a.

188. See HorowTZ, supra note 10 , at 121, 212-13.

189. See MiCHAEL FREDHOLM, BURMA: ETHNICITY AND INSURGENCY 35 (1993). 
woman in Sri Lanka was randomly dragged off a bus, "doused with gasoline, and set ablaze by a Sinhalese mob in which people danced and clapped their hands while she died in agony." ${ }^{190}$ In Kenya, after a military coup in 1982, the starkly economically dominant Indian minority was confronted with "the unleashed hatred of some of Kenya's 16 million African majority." ${ }^{191}$ Looters and rioters targeted Asian shops and businesses, smashed "what could not be looted," and raped at least twenty Indian women. ${ }^{192}$ In Tanzania, the retreat from a socialist economy in the 1980 s precipitated the "reemergence of the country's sizeable Asian minority as a powerful force in the economy." ${ }^{193}$ Majority fears that "the non-indigenous community [would] overwhelm and take over everything" led to bitter anti-Indian brutality. ${ }^{194}$ Zambia's "very greedy" Indians, who once were accused of purchasing the body parts of mutilated African children, recently were targeted in mass riots. In one participant's words: "Indians are the ones getting the chances. They've got millions and millions." 195

In Africa, nonindigenous minorities are not the only targets of resentment. There also have been ethnoeconomic reactions against economically dominant African minorities, at both the national and regional levels. In Kenya, post-independence urban growth (and ethnically-biased state policies) reinforced the economic prominence of the "capitalistic" Kikuyu, ${ }^{196}$ who in turn were terrorized and victimized by the Kalenjin, the "rightful" owners of the country. ${ }^{197}$ In Nigeria in 1966, tens of thousands of Ibo were slaughtered indiscriminately by resentful mobs. ${ }^{198}$ In both Rwanda and Burundi, the ethnocidal conflict between the Hutu majority and the Tutsi minority is inextricably connected with the historical socioeconomic

190. SOWELL, supra note 97 , at 28.

191. Alan Cowell, A Fearful Reminder Lingers for Asians in Kenya, N.Y. TIMES, Sept. 1, 1982, at A2; see also Himbara, supra note 113, at 470 (discussing the economic dominance of Indians in East Africa).

192. Cowell, supra note 191, at A20.

193. Keith B. Richburg, Tanzanian Reforms Opening up Socialist, One-Party, System, WASH. PosT, Mar. 24, 1992, at A14.

194. Id; see also Stephen Buckley, Policy Helps Tanzania Avoid Tribal Tensions Rife Elsewhere in Africa, WASH. POST, Nov. 7, 1995, at A15 (discussing Tanzania's Indian community).

195. Scott Straus, In Zambia, Race Hatred Simmers, BALT. SUN, Jan. 26, 1996, at 3A.

196. See Himbara, supra note 113, at 476-77; Frank Holmquist \& Michael Ford, Kenya: State and Civil Society the First Year After the Election, 41 AFR. TODAY, Fall 1994, at 7, 13; see also KENNEDY, supra note 148, at 93-96 (discussing competing explanations for "the rise of the mainly Kikuyu capitalist bourgeoisie" in Kenya). "Independence in 1963 brought Kenyatta to power as well as an ethnic bias toward the Kikuyu .... Kenyatta was followed by Moi in 1978 with his bias toward the Kalenjin ...." Holmquist \& Ford, supra, at 11.

197. Holmquist \& Ford, supra note 196, at 12; see id. at 5, 7-9, 13.

198. See SOWELL, supra note 97 , at 28. 
dominance of the latter. ${ }^{199}$ In Uganda in the 1960s and 1970s, the politically dominant groups of the north repeatedly subjected the economically dominant Baganda of the south to bloody purges. ${ }^{200}$ Dozens of other examples exist.

Depending on the context, the degree of the majority's resentment will vary. In Indonesia, for example, the Arab minority has provoked much less resentment than the Chinese. ${ }^{201}$ Resentment against the Lebanese-known as the "Jews of West Africa" ${ }^{202}$ and the "descendants of Judas" 203 in the Caribbean-also has been relatively mild. Nevertheless, in conditions of pervasive poverty, economically dominant ethnic minorities almost invariably have been the targets of ethnically charged resentment on the part of the relatively impoverished majorities around them.

To be sure, if market policies in a particular developing country succeeded in bringing rapid prosperity to the great majority of $M \mathrm{~s}$, the ethnoeconomic resentment predicted by the model might well be avoided. ${ }^{204}$ In model terms, a developing country that experiences such a "market miracle" effectively would have broken out of model conditions one (economic underdevelopment) and four (presence of an impoverished majority). Unfortunately, such a scenario has never yet unfolded in any developing country with a market-dominant minority. ${ }^{205}$

199. See LEMARCHAND, supra note 114, at 15-16; PRUNIER, supra note 114 , at 39 . In both Rwanda and Burundi, the Tutsi were also politically dominant for many years. See Gourevitch, supra note 150 , at 59 (describing periods of Tutsi political domination in Rwanda and Burundi before and after the colonial period).

200. See HoROWIZ, supra note 10, at 487, 490; MAMDANI, supra note 114, at 291.

201. See HoRowitz, supra note 10, at 117-18; Justus M. van der Kroef, The Arabs of Indonesia, 7 MIDDLE E. J. 300, 310, 311, 318 (1953).

202. SOWELL, supra note 97 , at 235.

203. Nicholls, supra note 115 , at 339,349 .

204. Even then, ethnic accord is by no means guaranteed. $C f$. Walker Connor, Ethnonationalism, in UNDERSTANDING POLITICAL DEVELOPMENT 196, 197 (Myron Weiner \& Samuel P. Huntington eds., 1987) (criticizing the unwarranted presumption "that the wellsprings of ethnic discord are economic and that an ethnic minority can be placated if its living standard is improving").

205. As discussed above, there are no market-dominant minorities in the East Asian Tigers. See supra text accompanying note 134 . More generally, market reforms rarely produce immediate and widespread benefits for large portions of the population. As Huntington has observed:

Economic liberalization ... may produce some immediate benefits for a few groups which are able to take advantage of new opportunities to make money. It is also very likely, however, to impose widespread and often severe economic penalties on much larger groups. Subsidies are ended, taxes are raised, budgets are balanced, workers are discharged, businesses go bankrupt, prices rise, wages fall and production declines. Enormous economic costs must be paid in order to achieve a promised long-term economic nirvana that seems to recede indefinitely into the future.

Huntington, supra note 2, at 25; see Przeworski, supra note 132, at 39 (suggesting that market reforms almost invariably "make most people worse off for some time to come"). 


\section{Hypothesis II: Ethnonationalism and Democratization}

Hypothesis II predicts that with democratization, the $M \mathrm{~s}^{\prime}$ ethnoeconomic resentment against the $M D M$ s will tend to be mobilized and transformed into a potent ethnonationalist political movement along the following lines:

Elections in X are about to take place. Deeply frustrated with their continuing poverty and resentful of the MDMs' economic dominance, the Ms are primed for an opportunity to set the ethnic balance straight. Politician $\mathrm{P}$, a shrewd and charismatic $\mathrm{M}$, seizes this opportunity. Deliberately fomenting the $\mathrm{Ms}$ ' frustration and fear, $\mathrm{P}$ scapegoats the MDMs, blaming them for X's economic and social problems-a strategy that allows $\mathrm{P}$ to appear populist despite his elite background. ${ }^{206}$ If possible, $\mathrm{P}$ depicts the MDMs as a political threat: as a dangerous (and preferably historical) enemy who want to "swallow up" the $\mathrm{Ms}{ }^{207}$ At first, more moderate candidates disavow $\mathrm{P}$ 's ethnic politics. $\mathrm{P}$, however, makes his rivals look like traitors. Soon, it becomes necessary for every candidate at least to champion the indigenous majority, if not to join in $\mathrm{P}$ 's more venomous rhetoric. In the process, the $\mathrm{Ms}$ ' ethnoeconomic resentment is politicized and transformed into an ethnonationalist movement that insists that $\mathrm{X}$ 's land, wealth, and identity must be reclaimed by the $\mathrm{Ms}$, the true owners of the nation.

The general link between democracy and ethnic conflict is well documented. ${ }^{208}$ Many scholars have shown that in severely divided societies

206. Cf. Mansfield \& Snyder, supra note 177 , at 86 (observing that in 1920 s Japan, the adoption of a nationalist strategy "scapegoating Japan's alleged internal and external enemies ... proved to be a way for militarist elite groups to appear populist in a democratizing society").

207. See, e.g., Horowitz, supra note 51, at 19 (discussing how "[a]n ethnically differentiated opposition can easily be depicted as consisting of ... historical enemies").

208. Throughout Africa, Asia, and the former Communist bloc, ethnic conflict has been a major reason for the failure of democratization. See, e.g., id. at 18-23; Michael Lind, A New Look at Nationalism: A Defense of Liberal Nationalism, CURRENT, Oct. 1994, at 30, 33. At the same time, "rapid democratization in autocratic societies often has correlated with heightened levels of ethnic conflict." Orentlicher, supra note 177, at 62 . Thus, Ted Gurr has observed that "[t]he Soviet and Eastern European regimes relaxed coercive constraints on nationalism and intergroup hostilities at a time when the institutionalized means for their expression and accommodation did not yet exist, or were fragile and distrusted. .. The result has been a resurgence of communal activism, both protest and rebellion." TED ROBERT GURR, MINORITIES AT RISK: A GLOBAL VIEW OF ETHNOPOLITICAL CONFLICTS 137 (1993); see also Mansfield \& Snyder, supra note 177, at 88 ("Democratization typically creates...h high-energy mass politics" and appeals to nationalism by "newly ambitious elites and the embattled old ruling groups"); Fareed Zakaria, The Rise of Illiberal Democracy, FoREIGN AFF., Nov./Dec. 1997, at 22; 35 ("[W]ithout a background in constitutional liberalism, the introduction of democracy in divided societies has actually fomented nationalism, ethnic conflict, and even war."). 
"where holding an election is like taking a census," 209 "the very process of political liberalization in democratizing autocracies presents new opportunities for increased ethnic mobilization" and a politics dominated by ethnic issues. ${ }^{210}$ More specifically, in democratizing countries with a resented, economically dominant minority, politicians seeking votes will have powerful incentives to scapegoat that minority and foment ethnic hatred. ${ }^{211}$ Indeed, as an empirical matter, democratization in the presence of an economically dominant minority has repeatedly given rise to potent ethnonationalist movements that seek to use political power to "correct" the ethnoeconomic imbalance.

In Malaysia, for example, laissez-faire market policies between 1957 and 1970 reinforced the economic dominance of the Chinese minority and provoked growing resentment among the Malays, particularly among the elites. ${ }^{212}$ In the ethnically charged atmosphere following the anti-Chinese riots of $1969,{ }^{213}$ numbers of vying political organizations sought to capitalize on the Malays' economic frustration and their fear of being "swallow[ed]" by the Chinese. ${ }^{214}$ Thus, Malay politicians, supported by other Malay elites, advanced the view that ethnoeconomic imbalances were at the heart of all Malaysia's problems, that herculean efforts to redistribute wealth to the Malays were imperative, and that their election to power was necessary if a "Malaysia for Malays" was to be realized. ${ }^{215}$ The result was a

209. Mansfield \& Snyder, supra note 177, at 87.

210. Orentlicher, supra note 177 , at 62 ; see Horowitz, supra note 51 , at 19 ; Mansfield \& Snyder, supra note 177 , at 87.

211. See, e.g., ESMAN, supra note 31, at 230-31 (citing examples of "officially inspired" scapegoating of middleman minorities in Eastern Europe, Southeast Asia, and Africa); Horowitz, supra note 177, at 255-56 (arguing that Malay politicians and elites deliberately highlighted ethnic disparities in wealth to achieve their own policy goals). There are different views as to why and how ethnic mobilization occurs. Primordialists emphasize the deep historical, social, and possibly even genetic foundations of ethnic identity and the "primal" need of individuals to defend that collective identity when it is threatened. See GURR \& HARF, supra note 139, at 78-79; Frye, supra note 33, at 607-08; supra note 31 and accompanying text. By contrast, instrumentalists view ethnic or national identity as "an artifact-the deliberate creation of political activists bent on mobilizing popular support." Binder, supra note 177, at 242; see BRASS, supra note 31, at 19-23; GURR \& HARFF, supra note 139, at 78-79. The model presented in this Article embraces various forms of ethnic mobilization, whether primordial, artifactual, or something in between.

212. See, e.g., David Brown, The State and EThnic Politics in Southeast asia 26, 230-31 (1994); Horowitz, supra note 177, at 255-56. At the same time, the Chinese, who in certain states comprise over $40 \%$ of the population, were increasingly seen as a political threat. See Horowitz, supra note 177, at 255.

213. These riots, in which nearly 1000 people died, followed on the heels of federal and state elections in which the Chinese opposition parties in the state of Selangor came close to taking power. See GoRDON P. MEANS, MALAYSIAN POLITICS: THE SECOND GENERATION 6-8 (1991); Horowitz, supra note 177, at 255.

214. HOROWIZ, supra note 10, at 190; see MEANS, supra note 213, at 3-4; Horowitz, supra note 177 , at 255-56.

215. See M. NAZRUL IslaM, PROBLEMS OF NATION-BUILDING IN DEVELOPING COUNTRIES: THE CASE OF MALAYSIA 71 (1988); MEANS, supra note 213, at 3-4; Horowitz, supra note 177 , at 255-56. 
powerful ethnonationalist consensus among Malays that they, the bumiputra ("sons of the soil"), were the only rightful owners of the nation. ${ }^{216}$ A year after the Kuala Lumpur riots, the government adopted the New Economic Program ("NEP") memorializing the special position of the Malays. ${ }^{217}$

In Sri Lanka, which has maintained a troubled parliamentary democracy for half a century, ${ }^{218}$ the disproportionate economic and political power of the Tamil minority had produced bitter resentment among the Sinhalese by the 1950 s. $^{219}$ There was thus "a huge untapped "vote bank" of frustrated Sinhalese that was waiting to be mobilized. Dennis Austin explains:

The times produced the man. Solomon Bandaranaike, for all his Oxford background, Catholic upbringing and legal training, was quick to see the prize that was there. He left the UNP, converted from Roman Catholicism to Buddhism, took up the cause of 'Sinhala Only' and began to campaign under the new socialist banner of a Sri Lanka Freedom Party. ${ }^{220}$

The "Sinhala Only" campaign united an unlikely array of Sinhalese forces, and in 1956, Bandaranaike's party swept to power on promises to declare Sinhala the sole national language and Buddhism the national religion. ${ }^{221}$ Within three months of Bandaranaike's election, the new Parliament enacted a bill proclaiming Sinhala the single national language. "222 "Sinhalisation"-accompanied by intensifying Tamil opposition and violence-accelerated under the leadership of Bandaranaike's widow, Sirimavo. ${ }^{223}$ "Elections easily became the opium of the newly enfranchised," 224 and today the Sinhalese, through constitutional

216. See BROWN, supra note 212, at 242. During the 1969 election campaign, Dr. Mahathir, who became Prime Minister in 1981, advised his Chinese constituents not to vote for him " as he would not represent their interests in Parliament." Id. (quoting $\mathrm{K}$. VON VORYS, DEMOCRACY WITHOUT CONSENSUS: COMMUNALISM AND POLITICAL STABILITY IN MALAYSLA 284 (1975)).

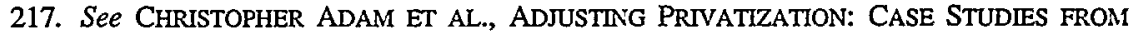
DEVELOPING COUNTRIES 224-25 (1992); Horowitz, supra note 177, at 266-68.

218. See DENNIS AUSTIN, DEMOCRACY AND VIOLENCE IN INDIA AND SRI LANKA at xvii (1994).

219. See id. at 66 .

220. Id.

221. Id. at 66-67 (footnote omitted).

222. See id. at 67.

223. Solomon Bandaranaike was assassinated in 1959. See id. In the 1970s, after an extended period of political turmoil and violence, Mrs. Bandaranaike forced through a new constitution dedicated to "protect[ing] and foster[ing] Buddhism," id. at 69, purged the state apparatus and armed forces of Christian and Tamil members, see id. at 69-70, and oversaw the adoption of sweeping anti-Tamil educational and economic policies, see id. at 70 \& n.18; HoROWTZ, supra note 10, at 663-66.

224. AUSTIN, supra note 218 , at 67 . 
and other policies, continue to shut out the Tamils. ${ }^{225}$ Meanwhile, Tamil guerrillas have retaliated ferociously. ${ }^{226}$

India, by contrast, does not appear to have an economically dominant ethnic minority at the national level. ${ }^{227}$ Nevertheless, democracy has meant ethnic politics in a growing list of Indian states. ${ }^{228}$ Furthermore, in regions of India where an economically dominant minority is present, Hypothesis II has been borne out directly. Thus, in Bombay in the late 1960s, the "nativist" Shiv Sena party rose to political prominence in just two years by attacking the economically dominant South Indian minority and championing "Maharashtra for Maharashtrians." 229 Around the same time in Telangana, the nativist Praja Samiti party gained political ascendancy by targeting and scapegoating the economically dominant coastal Andhra minority. ${ }^{230}$ More recently in Assam, a student-based Assamese party swept to power in 1985 by calling for the expulsion and disenfranchisement of economically dominant Bengali immigrants. ${ }^{231}$ In classic ethnonationalist rhetoric, Assam's new Chief Minister declared, “The jobs, the businesses and other economic activities and precious land which rightly belonged to the indigenous people have been grabbed by the outsiders." 232

225. See id. at $67-75$.

226. See id. at 68-71.

227. See id. at 8; Paul Brass, The Politics of India Since Independence, in Introduction to IV NEW CAMBRIDGE HISTORY OF INDIA 19-34 (1990), reprinted in ETHNICITY 301 (John Hutchinson \& Anthony D. Smith eds., 1996); Mira Kamdar, India: Multicultural Democracy at the Millennium, WORLD POL'Y J., Fall 1996, at 71.

228. See, e.g., BRASS, supra note 31, at 177-79 (analyzing Hindu-Sikh political polarization in Punjab); John F. Burns, A Violent Goal: Hindustan for Hindus, N.Y. TIMES, Nov. 3, 1995, at A6 (discussing Hindu nationalist political success in Maharashtra); Steven R. Weisman, Gandhi's Party Loses in Assam, N.Y. TIMES, Dec. 19, 1985, at A4 (stating that in a growing list of Indian states, including Andhra Pradesh, Assam, and Punjab, elections have been polarized along religious or sectarian lines).

229. KATZENSTEIN, supra note 110, at 18; see id. at 30,33-34; Myron Weiner, Political Change: Asia, Africa, and the Middle East, in UnderstandNa POLTICAL DEVELOPMENT, supra note 204, at 33, 36. The Shiv Sena fared well in Bombay electoral politics but not elsewhere in the Maharashtra state, where there was no conflict with South Indians. See HoROWTZ, supra note 10, at 38. After 1968, the Shiv Sena sought to enlargen its political base by shifting its criticism to "antinationalis[t]" groups like Muslims and Communists, though this effort was not successful. KATZENSTEN, supra note 110, at 34-35.

230. See KATZENSTEIN, supra note 110, at 30; Weiner, supra note 229 , at $217-19,238-40$, $244-45$.

231. See Weisman, supra note 228, at A4. For a description of the student-based Assam party, see generally Ashutosh Varshney, After the Assam Killings, CHRISTIAN SCI. MONITOR, Mar. 22, 1983, at 27. Although the Assamese student movement started on a general anti-Bengali note, calls for deportation technically were directed only at the relatively recent (and principally Muslim) Bengali immigrants from Bangladesh and not at the Hindu Bengalis who, for the most part, settled in Assam much earlier. See id.

232. Sanjoy Hazarika, India's Assam State Demanding Ban on Migration, N.Y. TMES, Sept. 13, 1987, at A12. India, Malaysia, and Sri Lanka are aberrational in their relatively stable (although by no means unproblematic) histories of democratization. In most of the developing world, where democracy has been tried, it has either failed altogether or proceeded much more fitfully, supplanted regularly by military coups and extended periods of authoritarianism. In these cases, too, democratization has generally borne out the model's second hypothesis. Thus, in one 
Hypothesis II is also corroborated by the recent (not always successful) transitions to democracy in the non-Russian republics of the former Soviet Union. Elections in these countries-where Russians for seventy years were economically and politically dominant-almost without exception have taken on potent ethnonationalist dimensions, as captured by slogans like "Estonia for Estonians," 233 "Georgia for the Georgians," 234 "Kazakhstanfor-the-Kazakhs," ${ }^{235}$ "Latvia for Latvians," ${ }^{236}$ "Lithuania for Lithuanians," 237 "Moldavia for Moldavians," 238 "Ukraine for Ukrainians," 239 and "Uzbekistan for Uzbeks." ${ }^{240}$ Typically, such slogans are followed by the enactment of legislation discriminating against ethnic Russians. ${ }^{241}$

Indeed, in virtually all of the cases discussed, ethnonationalist sloganeering during the electoral process has led to the election of leaders from a majority ethnic group and ultimately to the emergence of what

of the Philippines' first presidential elections, Ramon Magsaysay won a landslide victory in 1953 championing "Filipinization" and promising to "wrest" the country's retail sector from Chinese hands. GOLAY ET AL., supra note 95, at 65-66. In Haiti, in a succession of democratic experiments early this century, the "unpopular [Lebanese] ethnic minority became a convenient whipping boy for aspiring politicians." Nicholls, supra note 115, at 359. In Fiji, Lieutenant Colonel Sitiveni Rabuka came to power in 1987 in a bloodless coup championing "the Fijian way of life." Fiji Coup Leader Vows to Limit Indians' Power, L.A. TIMES, May 17, 1987, at 5 (quoting Rabuka's post-coup news conference). Since then, Rabuka has openly called for the departure from power of the "immigrant race" of Indians who want "complete control of Fiji." Bob Drogin, Trouble in Paradise: Behind Fiji's Façade, Turmoil Brews, L.A. Times, Sept. 24, 1991, at 2 (quoting from Rabuka's biography, "No Other Way") (citation omitted). In Fiji's 1992 elections, Rabuka and his party won 30 of the 37 parliamentary seats reserved for Fijians under a new constitution enacted in 1990. See Nikki Tait, A Divided Fiji Faces Further Division, Fin. TIMES, Feb. 18, 1994, at 4. In Kenya, which just reopened itself to multi-party elections in 1992, politicians are again championing the expulsion of Asians, who politicians allege have "taken over the economy and [are] exploiting native Africans." Greg Barrow, Kenyan Asians Fight Back as Politicians Call for Expulsion, GUARDIAN (London), June 19, 1996, at 13; see Jay Ross, Kenya's Asians Troubled by Criticism of Their Financial Dealings, WASH. POST, Apr. 3, 1982, at A19; Louise Tunbridge, Asians' Alarm at Kenya Call for Expulsions, DAILY TELEGRAPH (London), June 18, 1996, at 18. Politicians have also voiced concerns about "commercial imperialism" by the Kikuyu minority. See Holmquist \& Ford, supra note 196, at 13.

233. Mikhail Kalmykov, Estonia Urges Speedy Conclusion of Border Deal with Russia, RUSSIAN INFO. AGENCY ITAR-TASS, Jan. 27, 1997, available in LEXIS, Europe Library, TASS File.

234. René Lemarchand, The Siren Song of Self-Determination, UNESCO COURIER, June 1993 , at $29,30$.

235. Andrew Higgins, Russians Flee the Outposts of Empire; Settlers Fear for Future in Kazakhstan, INDEPENDENT (London), Feb. 12, 1995, at 15.

236. Juris Kaza, Tiny Baltic State Keeps Charging a Touchy Debate over Who Should Belong, ChRISTIAN SCI. MONITOR, Feb. 27, 1996, at 6. at 6.

237. Galina Afanasyeva, Lithuanian Fascism Becomes Legal, MosCow NEws, June 30, 1995

238. Horowitz, supra note 51, at 24.

239. Roger Boyes, Embers of Ancient Hatred Glow Again, Times (London), Aug. 19, 1996, at 14.

240. Frank Viviano, Ethnic Tensions Tear at Uzbekistan, S.F. CHRON., July 24, 1990, at A1.

241. For examples of such ethnonationalist legislation, see CHINN \& KAISER, supra note 127, at 103, 112-13, 228-29. 
scholars have called an "ethnocratic state," which acts as the agent of the majority ethnic group with respect to ideology, social policy, and resource distribution. ${ }^{242}$ In an ethnocratic state, recruitment to elite positions in the civil service, armed forces, and government is disproportionately and overwhelmingly from the ethnic majority. ${ }^{243}$ Moreover, the state's stance on language, religion, and moral values-that is, the national ideologyderives primarily from the culture of the ethnic majority. ${ }^{244}$ Finally, the constitutions, laws, and political structures of an ethnocratic state generally serve to reinforce the monopolization of power by the ethnic majority. ${ }^{245} \mathrm{In}$ these ways, "[i]n country after country, a single ethnic group has taken control over the state." 246

Once again, however, there may be an escape route-this time turning not on the extraordinary success of markets ${ }^{247}$ but on the extraordinary success of democracy. If in ethnically divided countries the democratic process itself could work a profound characterological change among voters-diffusing their ethnonationalism and permitting them to see all their fellow citizens as participants in a common enterprise-then Hypothesis II could be avoided. Unfortunately, in the developing world democracy does not appear to have this effect. On the contrary, as this Section has shown, democratization has had precisely the opposite effect, exacerbating ethnic tensions and galvanizing ethnonationalist movements in conditions of economic and political underdevelopment.

\section{Hypothesis III: Model Outcomes}

Thus far, the model has traced the formation of ethnoeconomic resentment against market-dominant minorities, the transformation of that resentment in the course of democratic electoral competition into an ethnonationalist political movement, and the subsequent installation of an ethnocratic state. Now consider the following scenario:

$\mathrm{P}$ comes to power in $\mathrm{X}$ on a platform of "X for the Ms." The state apparatus is now composed disproportionately of $\mathrm{Ms}$ and is openly regarded as the agent of the $\mathrm{M} \mathrm{s}^{\prime}$ interests. Due in part to his own electoral strategy, $\mathrm{P}$ confronts an aroused population of $\mathrm{Ms}$ who view the continued presence of the economically dominant MDMs

242. See BROWN, supra note 212, at 36-37; Weiner, supra note 229, at 35-37.

243. See BROWN, supra note 212 , at 36-37.

244. See id. at 37.

245. See id.

246. See Weiner, supra note 229 , at 35.

247. See supra text accompanying notes 204-205 (discussing the possibility of a "market miracle"). 
as intolerable. The $\mathrm{Ms}$ demand that $\mathrm{P}$ take decisive action in order to make good on his campaign rhetoric. What are $\mathrm{P}$ 's options?

In these circumstances, $P$ cannot both satisfy the democratic will and permit the $M D M$ s to continue operating under market conditions. Accordingly, Hypothesis III predicts that if the $M \mathrm{~s}^{\prime}$ ethnonationalism becomes sufficiently potent, one or more of three outcomes become highly probable: (1) an ethnically fueled, antimarket backlash; (2) measures aimed at eliminating the $M D M$ s; or (3) a retreat from democracy.

\section{a. Antimarket Backlash}

Time and again throughout the developing world, governments, both authoritarian and democratic, have responded to the "problem" of an economically dominant minority by adopting policies aimed at correcting the ethnoeconomic "imbalance." Such policies have rarely, if ever, taken the form of Western-style social welfare measures-that is, post-market redistributions administered by a relatively sophisticated state apparatus. On the contrary, ethnocratic states in these conditions characteristically have pursued ethnically targeted governmental intrusions into market processes, principally by nationalizing industries controlled by the resented minority or by imposing ethnically based restrictions on economic activity. ${ }^{248}$

Nationalization has been a recurrent phenomenon in the developing world. As I have shown elsewhere, conventional wisdom overemphasizes the extent to which nationalizations in the developing world have been based on socialist or communist ideals. ${ }^{249}$ Notwithstanding the Marxist rhetoric occasionally adopted by nationalizing leaders, nationalization programs in developing countries have almost never sought to eliminate private property or to eradicate all economic classes. ${ }^{250}$ On the contrary, in the vast majority of cases, nationalization in developing countries fundamentally has been an expression of economic nationalism, particularly directed at economically dominant ethnic minorities. ${ }^{251}$ To name just a few examples, ethnically targeted nationalizations or confiscations have occurred in postcolonial Burma, ${ }^{252}$ Indonesia, ${ }^{253} \mathrm{Kenya}^{254}$ Malaysia, ${ }^{255}$

248. See ESMAN, supra note 31 , at 231-32.

249. See Chua, supra note 18, at 261-62.

250. See id. at 262 . In only a few exceptional cases (for example, Cuba and Vietnam) has there been a full-fledged effort to eliminate private ownership of resources altogether. See id. at 302 n.582.

251. Nationalistic nationalizations have been directed not just at these ethnic "internal foreigners" but also at Western "imperialist" foreigners. Id. at 263-66.

252. See, e.g., GolAY ET AL., supra note 95, at 211; Chua, supra note 18, at 253-54, 270. 
Pakistan, ${ }^{256}$ the Philippines, ${ }^{257}$ Sri Lanka, ${ }^{258}$ Thailand, ${ }^{259}$ and Uganda ${ }^{260}$ and most recently have been championed by indigenous politicians in South Africa $^{261}$ and Zimbabwe. ${ }^{262}$

At the same time, ethnocratic governments also have attacked the economic power of economically dominant minorities by "supersed[ing] market processes of competition and manipulat[ing] the rules governing access for the benefit of their ethnic constituents." ${ }^{263}$ Nowhere have ethnically discriminatory economic restrictions been more prevalent than in Southeast Asia. Indeed, after World War II,

there was scarcely a country where the Chinese could pursue their callings or their commercial preferences without disapproval or interference. In Thailand Chinese aliens were excluded from twenty-seven occupations, in Cambodia from eighteen .... [T]o suffer harsh economic discrimination of one kind or another was part of being Southeast Asian Chinese. ${ }^{264}$

A stark but typical example is the "Filipinization" law passed in the Philippines in 1954 that explicitly banned the Chinese from "engag[ing] directly or indirectly in the retail business." ${ }^{265}$ The law was defended as "not the product of racial hostility, prejudice or discrimination, but the 269.

253. See, e.g., GOLAY ET AL., supra note 95 , at $137,166,193-95$; Chua, supra note 18 , at

254. See, e.g., Himbara, supra note 113 , at $470-72$.

255. See, e.g., Chua, supra note 18, at 247.

256. See, e.g., id. at $250-51$.

257. See, e.g., id. at 255.

258. See, e.g., id. at 269-70. 270.

259. See, e.g., GOLAY ET AL., supra note 95, at 299-306; Chua, supra note 18, at 251-52,

260. See, e.g., SAMUEl DeCalo, CouPS AND ARMY RULE IN AFRICA 174-75 (2d ed. 1990); MAMDANI, supra note 114, at 260-69. I have also shown that the waves of nationalizations earlier this century in Latin American countries like Bolivia, Mexico, and Peru had ethnic as well as class dimensions. See Chua, supra note 18, at 272-79.

261. See Chris McGreal, Bitterness over Land Grab, GuARDIAN (London), Jan. 2, 1998, at 11.

262. See Gumisai Mutume, South Africa-Economy: Thumbs Down for Privatization, INTER. PRESS SERV., July 1, 1997, available in LEXIS, News Library, INPRES File.

263. ESMAN, supra note 31, at 230; cf. SOWELL, supra note 97, at 266 (discussing antimarket economic policies enacted in Eastern Europe to counter the overrepresentation of Jews in commerce, industry, and the professions).

264. PAN, supra note 178, at 217.

265. GOLAY ET AL., supra note 95 , at 66-67; see also id. at 430 (describing similar legislation passed by Cambodia in 1957). An earlier manifestation of anti-Chinese legislation in the Philippines actually reached the United States Supreme Court. In 1926, when the Philippine Islands were under United States rule, the Supreme Court declared unconstitutional the Chinese Bookkeeping Act of the Philippines prohibiting the keeping of account books in any language other than English, Spanish, or a local Filipino dialect. See Yu Cong Eng v. Trinidad, 271 U.S. 500 (1926). Finding that the Act "was chiefly directed against ... Chinese merchants," most of whom spoke only Chinese, $i d$. at 511,513 , the Court held that the Act denied the Chinese equal protection of the laws in violation of the Philippine Bill of Rights. See id. at 524-25. 
expression of the legitimate desire or determination, of the people, through their authorized representatives, to free the nation from the economic situation that has unfortunately been saddled upon it ...."266

In a similar vein, in the late 1960s, Uganda's Prime Minister Obote passed laws establishing "a developmental socialism" largely to "cut the [economically dominant Baganda] down to size." ${ }^{267}$ Around the same time, Kenya passed a number of licensing and trade laws effectively barring Indians -including citizens of Kenya-from trading in rural areas and "all noncentral parts of major cities and towns." ${ }^{268}$ Although none of these three countries enforces these laws any longer, ethnically based restrictions are today robust in countries such as Fiji, ${ }^{269}$ Malaysia, ${ }^{270}$ Sri Lanka, ${ }^{271}$ and, as discussed further below, South Africa, ${ }^{272}$ as well as in the Indian states of Andhra Pradesh, Assam, and Maharashtra. ${ }^{273}$ Such restrictions-" the antithesis of laissez-faire" 274 but not necessarily normatively unjustifiedinclude ethnically based quotas on corporate asset ownership and other ethnically based restrictions on commerce, employment, finance, land ownership, licensing, and government contracts. ${ }^{275}$ This basic aspect of developing country commercial law is almost never discussed in the marketization literature.

266. GOLAY ET AL., supra note 95, at 66-67 n.77 (citation omitted); see VICTOR PURCELL, THE CHINESE IN SOUTHEAST AsIa 544-46 (2d ed. 1965); Antonio S. Tan, The Changing Identity of the Philippine Chinese, 1946-1984, in CHANGING IDENTTIES OF THE SOUTHEAST ASIAN CHINESE SINCE WORLD WAR II, at 177, 184 (Jennifer W. Cushman \& Wang Gungwu eds., 1988) (describing the law).

267. David E. Apter, Democracy for Uganda: A Case for Comparison (The Quest for World Order), 124 DAEDALUS 155, 156 (1995); see also MAMDANI, supra note 114, at 242-46 (describing the historical economic prominence in Uganda of the Buganda kingdom and the Obote government's anti-Baganda measures in 1966).

268. Himbara, supra note 113 , at 472 .

269. See HorowITZ, supra note 10, at 655; MICHAEL C. HOWARD, FIII: RACE AND POLITICS IN AN ISLAND STATE 333-34, 365 (1991); BRIJ V. LAL, BROKEN WAVES: A HISTORY OF THE FIJI ISLANDS IN THE TWENTIETH CENTURY 224-27 (1992).

270. See ADAM ET AL., supra note 217, at 214-15; HOROWITZ, supra note 10 , at 654 ; Horowitz, supra note 177, at 264-71.

271. See AUSTIN, supra note 218, at 70, 82; Chandra Richard de Silva, Sinhala-Tamil Ethnic Rivalry: The Background, in FROM INDEPENDENCE TO STATEHOOD 111, 118, 211 (Robert B. Goldmann \& A. Jeyaratnam Wilson eds., 1984); Chandra Richard de Silva, Sinhala-Tamil Relations and Education in Sri Lanka: The University Admissions Issue-The First Phase, 197177 , in FROM INDEPENDENCE TO STATEHOOD, supra, at 125, 130-31.

272. See infra Section V.A.

273. See HoRowITZ, supra note 10, at 656-57; Myron Weiner, The Pursuit of Ethnic Equality Through Preferential Policies: A Comparative Public Policy Perspective, in FroM INDEPENDENCE TO STATEHOOD, supra note 271, at 63, 73-74.

274. GOLAY ET AL., supra note 95, at 35.

275. See, e.g., ADAM ET AL., supra note 217, at 214-15 (describing NEP in Malaysia); HoROWTz, supra note 10, at 654-56 (describing general range of preferential programs in ethnically divided societies); HowARD, supra note 269, at 333-34 (describing restrictions on land ownership in Fiji); KATZENSTEIN, supra note 110, at 143-45 (describing employment quotas and other "nativist" policies in Maharashtria); Suryadinata, supra note 97, at 770-71 (describing antiChinese policies in Indonesia). 


\section{b. Eliminationist or Final "Solutions"}

As a historical matter, ethnically discriminatory nationalizations and commercial restrictions have almost invariably backfired. On the one hand, they have had drastically negative economic effects. ${ }^{276}$ In particular, nationalization (often euphemistically labeled "state capitalism" or "bureaucratic entrepreneurship" $)^{277}$ in the developing world repeatedly has resulted in grossly inefficient, corrupt government enterprises. ${ }^{278}$ On the other hand, ethnically targeted restrictions have proven notoriously ineffective; economically dominant minorities have managed to frustrate such restrictions consistently through evasion (e.g., bribery or use of indigenous frontmen) or sheer indispensability. ${ }^{279}$ As a result, ethnically based backlashes against the market do not satisfy-and may even exacerbate- the ethnonationalist demands that generated them. ${ }^{280}$

To respond to increasingly virulent majority pressures, $P$ may move to more draconian measures targeting the $M D M \mathrm{~s}$, ranging from oppressive exclusionary policies to forced repatriation or expulsion, and finally (in some cases) to pogroms, extermination, and genocide. ${ }^{281}$ Throughout the developing world, majority-based governments have responded to the economic dominance of hated minorities by trying in effect to eliminate them. The least egregious of such eliminationist strategies include burdensome language requirements, discriminatory immigration and citizenship policies, discriminatory policies for admission to education, and policies designed to eradicate the resented minority culture. ${ }^{282}$

276. See ESMAN, supra note 31, at 231-32; Himbara, supra note 113, at 474-77.

277. GOLAY ET AL., supra note 95, at 58; Himbara, supra note 113, at 474 .

278. See, e.g., GOLAY ET AL., supra note 95 , at 56-57 (describing the corruption, inefficiency, and heavy losses incurred by government corporations in the Philippines); Himbara, supra note 113 , at 474 (noting that Kenya's "state capitalism" program in the late 1970s and early 1980s led to widespread corruption and gross inefficiency); Shirley, supra note 88, at S32 (noting that public enterprises in the developing world are typically unproductive and inefficient and often require government bail-outs financed through taxes or inflation).

279. See Bonacich, supra note 95, at 592. For example, in Southeast Asia, "[a]ttempts to control the Chinese [through] [1]icensing systems have been thwarted by the willingness of indigenous businessmen, whom they were intended to benefit, to sell their import and export permits to the Chinese who possessed what they lacked-organization, contacts, experience and capital." Id. (citation omitted).

280. To return to the terms of the model: X's economy is now stagnating under the massive inefficiencies of state-run, "indigenized" enterprises, and most $M s$ are probably worse off than before $P$ was elected. See, e.g., ADAM ET AL., supra note 217, at 226 (noting that Malaysia's indigenization drive in the $1970 \mathrm{~s}$ "failed to maintain the value of assets appropriated for the Bumiputra"); Himbara, supra note 113, at 474-75 (detailing the dismal and thoroughgoing failure of Kenya's "Africanization" program).

281. See BROWN, supra note 212, at 27; ESMAN, supra note 31, at 231-32; Bonacich, supra note 95 , at 592 .

282. See, e.g., AUSTIN, supra note 218, at 67; (describing Sri Lanka's "Sinhala Only" bill declaring Sinhala to be the sole national language); HoROWTZ, supra note 10, at 660-66 (describing ethnic preferences in education in Malaysia, Sri Lanka, and Tanzania); Suryadinata, 
Such discriminatory policies have led to the elimination of the resented minority in one of two ways. First, policies of ethnic exclusion have frequently led to massive emigrations. In the 1950 s and $1960 \mathrm{~s}$, for example, state-condoned prejudice and policies targeting the Chinese in Indonesia and the Indians in Burma led to the flight of thousands of people. ${ }^{283}$ In Rwanda, anti-Tutsi policies initiated by Hutu leaders "started a mass exodus of refugees abroad, which eventually took some 130,000 Rwandese Tutsi to the Belgian Congo, Burundi, Tanganyika and Uganda by late 1963." 284 In Kenya, thousands of Indians have left in the last few years, fearing a "wholesale expulsion of Asians." ${ }^{285}$ In Fiji, calls for the mass deportation of Indians coupled with ethnic violence have caused over 30,000 Indians to leave the island since $1987 .{ }^{286}$ Finally, since the late 1980 s, emerging ethnonationalist movements in virtually all of the nonRussian republics of the former Soviet Union have spawned discrimination against the Russian-speaking population ranging "from subtle prejudice and discriminatory language and citizenship laws, to job-firings and even violence." 287 As a result, more than two million Russians and other Russophone nationals have "abandon[ed] their homes" for "the disarray of post-Soviet Russia." 288

Second, exclusionary policies sometimes have had the goal-and, to a lesser extent, the effect-of coerced assimilation. For example, in Southeast Asian countries such as Indonesia and Vietnam, mandatory naturalization laws, bans on Chinese language newspapers, schools, and movies, restrictions on "Chinese religion, beliefs and customs," and name change policies sought to absorb the Chinese into the indigenous community and

supra note 97 , at 780 (describing language bans and discriminatory education policies targeting the Chinese minority in Indonesia).

283. See M.C. RICKIEFS, A HISTORY OF MODERN INDONESIA SINCE C. 1300, at 267 (2d ed. 1993) (describing the exodus of Indonesian Chinese following the 1959 enactment of a decree banning "aliens" from rural trade); J.A.C. Mackie, Anti-Chinese Outbreaks in Indonesia, 195968 , in THE CHINESE IN INDONESIA 77, 120 (J.A.C. Mackie ed., 1976) (describing the persecution of the Chinese in Indonesia); Martin Smith, Burma's Ethnic Minorities: A Central or Peripheral Problem in the Regional Context?, in BURMA: THE CHALLENGE OF CHANGE IN A DIvIDED SOCIETY 101 (Peter Carey ed., 1997) (stating that 300,000 Indians left Burma following Ne Win's mass nationalizations during the 1960 s).

284. PRUNIER, supra note 114 , at 51 (citation omitted).

285. Ross, supra note 232, at A19.

286. See Philip Shenon, Fiji Uproar over Plan to Bring in Chinese, N.Y. TIMES, Oct. 5, 1995, at A9; Tait, supra note 232, at 4.

287. Robert P. Devecchi, Prepared Testimony on Forced Migration in the Newly Independent States of the Former Soviet Union Before the House Commitee on International Relations and Subcommittee on International Operations and Human Rights (May 22, 1996), in FEDERAL NEwS SERVICE, available in LEXIS, News library, FEDNEW file; see also CHINN \& KAISER, supra note 127, at 190, 194, 198-201. Emigration rates (i.e., Russian emigrants as a percentage of the Russian population) from 1989 and 1993 were $10.4 \%$ in Lithuania, $10.9 \%$ in Uzbekistan, $17.1 \%$ in Kyrgyzstan, 28\% in Georgia, 31.1\% in Azerbaijan, and 35.6\% in Armenia. See id. at 95, 231, 245.

288. Id. 
thus to eliminate them as a distinct ethnic minority. ${ }^{289}$ For many students of ethnic conflict, assimilation represents a glimmer of hope for societies long riven by ethnic hatred. ${ }^{290}$ Others view assimilation as "cultural genocide." ${ }^{291}$ In any event, assimilation is not always possible or effective. ${ }^{292}$

Developing world leaders also have found more direct ways to eliminate economically successful "outsider" minorities. ${ }^{293}$ Following a pattern exemplified by the extraordinary history of Jewish expulsions, ${ }^{294}$ Indonesia ejected the Chinese en masse in $1960^{295}$ and Vietnam did the same in the late 1970s. ${ }^{296}$ In Cambodia, the Khmer Rouge expelled thousands of Vietnamese between 1975 and 1978. ${ }^{297}$ In Burma during the Second World War, an estimated 500,000 Indians were chased out of the country by young nationalists of the Burma Independence Army ${ }^{298}$ In

289. See, e.g., GOLAY ET AL., supra note 95, at 404-06 (describing attempts to assimilate the Chinese in Vietnam); Suryadinata, supra note 97 , at $776-82$ (describing assimilationist educational and cultural policies directed at the Chinese minority in Indonesia).

290. See, e.g., Wendell Bell, Ethnicity, Decisions of Nationhood, and Images of the Future, in ETHNICITY AND NATION-BUILDING: COMPARATIVE INTERNATIONAL AND HISTORICAL PERSPECTIVES 285-86 (Wendell Bell \& Walter E. Freeman eds., 1974) (asserting the possibility of assimilation into a single global culture); Horowitz, supra note 51, at 19 (observing that in Taiwan and Thailand rates of ethnic intermarriage correlated positively with improved ethnic relations and with prospects for democracy).

291. Neil Gotanda, A Critique of "Our Constitution Is Color-Blind," 44 STAN. L. REV. 1, 60 (1991); see, e.g., CORNEL WEST, RACE MATTERS 15-16 (1993); Wendy Brown-Scott, The Communitarian State: Lawlessness or Law Reform for African Americans?, 107 HARV. L. REV. 1209, 1224-26 (1994); Deborah Waire Post, Reflections on Identity, Diversity and Morality, 6 BERKELEY WOMEN's L.J. 136, 161-62 (1990-91); Gerald Torres, Local Knowledge, Local Color: Critical Legal Studies and the Law of Race Relations, 25 SAN DIEGO L. REv. 1043, 1062 (1988).

292. The assimilation of many Eastern European Jews, for example, in Czechoslavakia, Hungary, Latvia, and Romania had little or no effect on their ultimate fate in the Holocaust. See SOWELL, supra note 97 , at 267.

293. See Weiner, supra note 229 , at 36.

294. The Jewish Exodus from Egypt took place some time between 1450 and 1200 B.C. See MICHAEL GRANT, THE JEWS IN THE ROMAN WORLD 8 (1973). Subsequently, Jews were expelled from Rome in 139 B.C. (although Jews do not appear to have been economically dominant in ancient times). See id. at 31. They were, furthermore, expelled from England in 1290, France in 1394, Spain in 1492, Cologne in 1424, Augsburg in 1439, and Moravia in 1454. See SowELL, supra note 97 , at $236,242,248$. The wealth that the Spanish Jews were forced to leave behind helped finance the voyage of Columbus that led to the discovery of the Western Hemisphere. See $i d$. at 248. In Russia, anti-Jewish pogroms in the 1880s "set off one of the great mass exoduses in history." Id. at 264.

295. See PAN, supra note 178, at 217; RICKLEFS, supra note 283, at 267.

296. See SowELL, supra note 97, at 212. The mass exodus of Chinese from Vietnam in 19771978 also reflected in part deteriorating relations between Vietnam and China. See RAMSES AMER, THE ETHNIC CHINESE IN VIETNAM AND SINO-VIETNAMESE RELATIONS 50 (1991); YUANLI WU \& CHUN-HSI WU, ECONOMIC DEVELOPMENT IN SOUTHEAST ASIA 86 (1980). According to the Vietnamese government, only those Chinese illegally residing in Vietnam were being expelled. See AMER, supra, at 48. The Chinese version of the expuIsions was very different. See id. at 47. For an evenhanded discussion of the Sino-Vietnamese dispute surrounding the exodus of Chinese from North Vietnam to China, see id. at 46-53, 57-80.

297. See Tarr, supra note 107 , at 33 .

298. See Smith, supra note 283, at 101; Weiner, supra note 229, at 36 . 
Uganda, Idi Amin deported all Indians and Pakistanis in 1972, then distributed their assets as spoils to his military officers. ${ }^{299}$ In most of these cases, the economy suffered drastically as a result of the expulsions. ${ }^{300}$

Finally, economically dominant minorities have been eliminated through pogroms, mass killings, and genocide. In the Philippines, Spanish colonialists massacred all but 2000 of Manila's 26,000 member Chinese minority in $1603 .^{301}$ Chinese also were killed en masse in Vietnam in $1792^{302}$ and in Indonesia in 1965 and $1966 .{ }^{303}$ In Cambodia, "[i]n an orgy of violence" in 1970, "more than 4000 Vietnamese were killed in under a month." 304 Two hundred thousand Chinese-half of the Chinese population in Cambodia-were subsequently killed between 1975 and $1979 .{ }^{305}$ In Burma, thousands of Indians were killed in the 1930s and 1940s. ${ }^{306}$ Most recently in Rwanda, between 500,000 and 1,000,000 Tutsi were exterminated from April to June $1994 .^{307}$

As noted earlier, I do not argue that economic factors alone motivated these atrocities. I also do not claim that nonprosperous ethnic minorities are never persecuted. Nonetheless, it remains the case that in country after country, large populations of economically dominant ethnic minorities repeatedly have been subjected to severe reprisals, ranging from cultural oppression to extermination.

\section{c. Retreat from Democracy}

The previous two outcomes contemplate an ethnocratic government acting in accordance with majoritarian ethnonationalist sentiment (which the government itself may have incited) through either market interventions or eliminationist measures. In the third model outcome, the government defies the democratic will and seeks to accommodate the resented marketdominant minority. There are several reasons why an ethnocratic leader might adopt this pro-market but antidemocratic strategy. He might, for example, wish to harness the minority's skills to revive his country's

299. See DECALO, supra note 260, at 17476; MAMDANI, supra note 114 , at 302-12.

300. See SowELL, supra note 97 , at 322 ; Weiner, supra note 229 , at 36 . Out of "economic desperation," some governments later sought the return of the minorities they had expelled SOWELL, supra note 97 , at 322.

301. See Morella, supra note 103; cf. PURCELL, supra note 266, at 501, 513-14 (explaining that about 23,000 Chinese were killed in 1603); DAVID JOEL STEINBERG, THE PHILIPPINES 40-41 (2d ed. 1990) (discussing hostility towards the Chinese majority).

302. See Harish Mehta, Ups and Downs of Chinese Businessmen in Vietnam, BUS. TMIES (Singapore), June 30, 1994, at 16.

303. See PAN, supra note 178 , at 218 .

304. Tarr, supra note 107 , at 34.

305. See SoWELL, supra note 97 , at 213 ; Tarr, supra note 107 , at 34.

306. See FREDHOLM, supra note 189, at 29-37; SMITH, supra note 108, at 44 .

307. See PRUNIER, supra note 114, at 263; Morris, supra note 90, at 350. 
flagging economy. Alternatively, he and his cohorts may simply have been "bought out" by the wealthy minority. Or he may have been subject to overwhelming pressure from international organizations and international business interests. In any event, the pursuit of ethnically tolerant policies in the face of an aroused, ethnonationalist majority almost invariably has required a significant retreat from democracy.

In some cases, this retreat is obvious, as when an accommodationist leader disbands the legislature, cancels elections, or otherwise suppresses political competition. The autocratic regime of Indonesia's General Suharto provides an example of this phenomenon. Suharto seized power militarily in 1965, bringing to an end the "guided democracy" of his predecessor Sukarno, ${ }^{308}$ whose economic policies-including the nationalization and "indigenization" of major industries-had produced catastrophic results. ${ }^{309}$ Suharto proceeded to quash rival political parties and to extinguish opposition of all types. ${ }^{310}$ In return for the support of the World Bank and the IMF, Suharto's government adopted open door laissez-faire policies to encourage foreign investment and rapid economic growth. ${ }^{311}$ To that end, after an early "unprecedently radical" crackdown on the Chinese in East Java, Suharto reached out to the Chinese business community. ${ }^{312}$ Indeed, beyond simply granting the Chinese economic freedom, Suharto affirmatively directed "lucrative rent-seeking opportunities to them." ${ }^{313}$ In exchange, the Indonesian Chinese, with their "business expertise, international connections, and preexisting business links with the armed forces," ${ }^{314}$ financed Suharto's pet projects, both personal and public, ${ }^{315}$ while at the same time serving as "miracle workers" for Indonesia's economic development. ${ }^{316}$ The resulting resurgence of Chinese economic dominance contributed to rising pribumi resentment and left the Chinese "uncomfortably dependent" on the aging Suharto for protection. ${ }^{317}$

308. RICKLEFS, supra note 283 , at 287-89.

309. GOLAY ET AL., supra note 95, at 192-98; see also D.R. SARDESAI, SOUTHEAST ASIA 266-67, 272 (4th ed. 1997) (describing "the economic morass and bankruptcy" brought on by Sukarno's economic policies).

310. See RICKLEFS, supra note 283, at 287-88, 294, 299; John Colmey, Life on the Run with Indonesia's Democratic Outlaws, TIME, May 26, 1997, at 46.

311. See RICKLEFS, supra note 283 , at 291.

312. Mackie, supra note 283 , at 120.

313. William Ascher, From Oil to Timber: The Political Economy of Off-Budget Development Financing in Indonesia, 65 INDON. 37, 53 (1998).

314. Id. at 55.

315. See id. at 54-55. Thus, Indonesian Chinese businessmen have reportedly covered over $\$ 400$ million in foreign-exchange losses of the Bank Duta, which is indirectly owned.by Suharto; paid for the Taman Mini theme park monorail as a favor to Suharto's wife; financed a biography of Suharto; and, most recently, salvaged Indonesia's newly established but collapsing petrochemical industry. See id.

316. G. Bruce Knecht, Wealth Hazards, NAT'L REv., Nov. 21, 1994, at 56; see Ong Hock Chuan, Indonesian Riots Force Income Gap into Spotlight, ASIA TIMES, Jan. 6, 1997, at 1.

317. Knecht, supra note 316 , at 57. 
Suharto's resignation, coupled with the recent outburst of anti-Chinese violence, confirm that Indonesia remains enmeshed in the model dynamic described here. ${ }^{318}$

Even short of abolishing legislatures or canceling elections, majorityelected leaders also can thwart democracy by permitting themselves to be bought off by the resented ethnic minority. Although a certain amount of corruption is perhaps inevitable, too much corruption effectively can subvert the political process, replacing democracy with kleptocracy. ${ }^{319}$

The most extreme retreat from democracy in defiance of an ethnic majority occurs when an economically dominant ethnic minority itself seizes political power. Prime examples of autocratic rule by economically powerful ethnic minorities are South Africa under the apartheid regime, Rwanda and Burundi under Tutsi-dominated military rule; ${ }^{321}$ and decades of Kikuyu-dominated politics and exclusion in Kenya. ${ }^{322}$ As I have argued elsewhere, the social structure of many Latin American countries also can be viewed as a variation on the same dynamic. ${ }^{323}$

In summary, the model hypothesizes that, in developing countries satisfying the model conditions, the combined pursuit of marketization and democratization will produce powerful pressures likely to lead to one or more of three outcomes: (1) an ethnically fueled backlash against markets; (2) a backlash against the resented minority; or (3) a retreat from democracy. The history of the developing world repeatedly and consistently has corroborated these predicted outcomes. Nevertheless, in the next Section I discuss potential counterexamples to the model. I then address certain factors that may complicate the application of the model to realworld cases.

318. Cf. Borsuk \& Brauchli, supra note 185 , at A8 (discussing Suharto's resignation in the face of "deadly riots" and "social and economic chaos"); Schmetzer, supra note 185, at 4 (describing the recent violence targeting Indonesia's "hated [Chinese] merchant class").

319. See, e.g., Daniel King \& Jim LoGerfo, Thailand: Toward Democratic Stability, J. DEMOCRACY, Jan. 1996, at 102, 115. A well known example of this phenomenon is the ostensibly democratic but notoriously corrupt Philippines regime of Ferdinand Marcos (before he declared martial law), which was very friendly to Chinese economic interests. See, e.g., STERLING SEAGRAVE, THE MARCOS DYNASTY 22-25, 286-88, 377-79 (1988) (describing the close personal and business links between Ferdinand Marcos and wealthy Filipino Chinese); see also infra Subsection TV.D.1.b.

320. See GURR \& HARFF, supra note 139 , at 24.

321. See Gourevitch, supra note 150 , at 58-59.

322. See Donald L. HorowITZ, A DEMOCRATIC South Africa? 86 (1991). Needless to say, not all members of such politically dominant minorities benefit equally. Iraq's ruling elite, for example, "consists of a small clique within the Sunni Muslim minority, most of whom come from Saddam Hussein's hometown of Tikrit.” GURR \& HARFF, supra note 139, at 24.

323. See Chua, supra note 18, at 274-76; supra notes 116-118. 


\section{Potential Exceptions and Complications}

The model hypotheses are not intended to be universal laws of nature. Somewhere in the developing world a country may exist in which an impoverished majority feels no resentment against a rich, market-dominant minority-or at least not sufficient resentment to trigger the model outcomes. Indeed, this is arguably the case in present day Thailand and the Philippines, two often-cited "success stories" for free-market democracy in the developing world. ${ }^{324}$ Closer examination, however, reveals that these countries may not be exceptions to the model but instead may actually confirm it.

\section{Possible Negative Cases}

\section{a. Thailand}

In Thailand, which began democratizing in 1992 and has a more or less established market economy, ${ }^{325}$ relations today between the Thai majority and the economically dominant Chinese minority appear to be excellent. ${ }^{326}$ Historically, however, anti-Chinese resentment certainly existed. It was Thailand's King Vajiravudh who coined the term "Jews of the Orient." 327 Moreover, beginning in the late 1930s and recommencing in the 1950s, the Thai government adopted a series of antimarket policies aimed at counteracting the growing economic power of the Thai Chinese. ${ }^{328}$

324. See, e.g., Carl Lande, Consensus Politics and Economic Growth, BUS. TIMES (Singapore), Jan. 28, 1995, at 3 (expressing optimism about the prospects for Philippine democracy and economic growth); Lennox Samuels, Thailand Looks West in Move to Democracy, DALlAS MORNING NEwS, Dec. 26, 1996, at 1A (noting that many people view Thailand as having successfully expanded "Western-style" democracy while maintaining robust economic growth).

325. See HaGgard \& KAUfMaN, supra note 3, at 103-06, 242-44, 248; Peter Eng, Thais Hesitantly Remember, BALT. SUN, June 1, 1997, at 5F.

326. See, e.g., Horowitz, supra note 51, at 19 (noting that, compared to earlier decades, relations between Thais and Chinese are now "far less prone to conflict, and rates of intermarriage [are] higher than is typical of deeply divided countries"); Fallows, supra note 186, at 18 ("Compared to the situation in neighboring countries, racial frictions in Thailand are mild.... Chinese Thai and ethnic Thai alike seem to have agreed to act as if they share a common nationality.").

327. VELLA, supra note 172, at 193-94.

328. These policies included the nationalization of Chinese-dominated industries, the creation of a state corporation designed to compete with Chinese in the rice, salt, tobacco, petroleum, and pork trades, and the enactment of a host of anti-Chinese commercial restrictions-all consistent with model outcome one. See GolaY ET AL., supra note 95, at 300-05; DAVID K. WYATT, THAILAND: A SHORT HISTORY 254 (1984); Songprasert, supra note 143, at 119, 122-23; $\mathrm{Ng}$ Chee Yuen \& Norbert Wagner, Privatization and Deregulation in ASEAN: An Overview, ASEAN ECON. BULL., Mar. 1989, at 212. 
Starting in the 1930s, the Thai government began a systematic and often ruthless campaign to assimilate the Chinese into Thai society. ${ }^{329}$ The use of the Chinese language was restricted, Chinese schools were monitored, newspapers were shut down, and Chinese culture was generally suppressed. ${ }^{330}$ More subtle pressures for assimiliation played a role as well. For example, in the 1960s and 1970s, the "ladder to success in [Thailand] ... consisted of Thai education, Thai surnames, Thai language, and even intermarriage with Thai families." ${ }^{331}$ In any event, for reasons about which many have speculated (including the close cultural affinity between the Thais and the Chinese $e^{332}$ as well as the supposed relative receptivity of Thais to foreigners $\mathrm{s}^{333}$ ), "Chinese have almost blissfully assimilated into Buddhist Thailand." 334

In Thailand today, many Thai Chinese speak only Thai, intermarry with Thais, and consider themselves as Thai as their indigenous counterparts. ${ }^{335}$ Although half of Bangkok is thought to be of some Chinese ancestry, the Thai Chinese generally feel no allegiance to China. ${ }^{336}$ Perhaps most strikingly, the country's top political leaders, including the current Prime Minister, are often of Chinese descent, ${ }^{337}$ although they frequently have Thai surnames and speak little or no Chinese. In fact, the current equilibrium in Thailand suggests a manifestation of model outcome two: To the extent the Thai Chinese have assumed the ethnic identity of the Thai majority, they effectively have been eliminated as a distinct ethnic minority. ${ }^{338}$ Even if this outcome proves stabilizing and seems benign, it is open to question whether an assimilationism achieved through decades of

329. See WYATT, supra note 328 , at 254-55.

330. See id. Today, there are still restrictions on the use of the Chinese language. A local cable television network recently was forced to cancel its Chinese-language shows "after the government cited standing regulations limiting broadcasts to Thai or English with Thai subtitles." Vatikiotis, supra note 186, at 23.

331. WYATT, supra note 328 , at 292.

332. "Thais and Chinese began with the same ethnic roots. Most Thais descend from people who lived in southwestern China until they were forced southward by the Mongols." G. Bruce Knecht, Thais That Bind, NAT'L REv., Nov. 21, 1994, at 58. Moreover, "[h]istorically, Thailand's relations with China were close. Thai kings paid tribute to China's medieval emperors. In return, China offered a lucrative trading relationship." Michael Vatikiotis, Ties That Bind, FAR. E. ECON. REV., Jan. 11, 1996, at 24, 25. Finally, it is said that Thailand "absorbed Chinese culture as part of Thai culture." Vatikiotis, supra note 186, at 24.

333. For a controversial comparison of the "receptivity" of the Thai as compared with the Javanese, see G. Wiliam Skinner, Change and Persistence in Chinese Culture Overseas: A Comparison of Thailand and Java, 16 J.S. SEAS SOC'Y 86 (1960).

334. Knecht, supra note 316, at 59.

335. See La Croix, supra note 153, at 221; Vatikiotis, supra note 186, at 22.

336. See Vatikiotis, supra note 186 , at 24 ; Knecht, supra note 332 , at 58.

337. See Vatikiotis, supra note 186, at 23. Chuan Leekpai, who is of Hokkien Chinese origin, reassumed Thailand's prime ministership in 1997. See Ted Bardacke, Banharn 'Broke Electoral Law, 'FIN. Times, Sept. 20, 1996, at 4; Nayan Chanda, Blown Away, FAR E. ECON. REv., Dec. 25,1997 \& Jan. 1, 1998, at 22, 26.

338. See sources cited supra note 291. 
cultural eradication and economic discrimination is an end that justifies its means.

A final recent twist is worth noting here. With the growing power of China in the last several years-not to mention expanding business opportunities on the mainland-an increasing number of Thai Chinese are reclaiming their Chinese identity. For example, many Thai Chinese are sending their children to newly-established Chinese language schools, visiting China in record numbers, and reassuming Chinese surnames. ${ }^{339}$ Whether this counterassimilationist trend in Thailand will eventually have a destabilizing effect remains to be seen.

\section{b. The Philippines}

Another possible counterexample to the model is the contemporary Philippines. While most Filipinos have some Chinese ancestry, there remains a discrete and insular "pure" Chinese minority who control an extraordinarily disproportionate share of the nation's wealth, who speak Chinese, seldom intermarry with Filipinos, and generally are viewed as aggressive, secretive, and clannish. ${ }^{340}$ Yet, arguably, despite the presence of a market-dominant minority, marketization and democratization in the Philippines have successfully proceeded without triggering any of the negative consequences predicted by the model. ${ }^{341}$

This argument, however, may reflect a naive view of democracy in the Philippines. Despite President Clinton's recent praises, ${ }^{342}$ the Philippines may in fact exemplify a variant of model outcome three. Since colonial Spanish times, a small hacendero class has controlled the country's politics by using their land ownership and influence over tenants. Well before Ferdinand Marcos's crony dictatorship,

[b]ehind the facade of democracy stood the fundamental fact that.... [a] few self-aggrandizing rich families controlled every facet of society. Washington was proud that its former colony had become a showcase of political democracy and downplayed the fact

339. See Vatikiotis, supra note 186 , at 22-23.

340. See Richburg, supra note 102, at A25.

341. The Philippines has been described as experiencing a "resurgence of democracy." Maritis D. Vitug, Sentimental Journey, FLIPINAS MAG., Jan. 31, 1995, at 11. Former President Fidel Ramos championed the courting of foreign investment and a free-market economy generally. See Clark D. NeHer \& Ross Marlay, Democracy and DeVElopMent IN SOUTHEAST ASIA 59 (1995). Current President Joseph Estrada has remained dedicated to freemarket policies, rejecting currency controls as a method of protecting the Philippine economy from the spread of the recent Asian market crises. See Philippine Industrialist Defends Currency Control Proposals, DeUTSChe PRESSE-AGENTUR, Sept. 16, 1998, available in LEXIS, News Library, DPA File.

342. See Vitug, supra note 341 , at 11. 
that the same families who had dominated their respective provinces for centuries now controlled the Senate and the House of Representatives. ${ }^{343}$

Moreover, despite her "People Power" platform, commentators agree that President Corazon Aquino-herself heir to a huge hacienda-"hardly made a dent in the personalistic, patrimonial system that was antithetical to democracy." 344 During Aquino's presidency, "of the 200 elected congressional representatives, 132 came from established landowning families and another 39 were relatives of big landowners." ${ }^{345}$ Not surprisingly, no significant land reform has yet occurred in the Philippines. ${ }^{346}$ Today, a few dynastic families continue to "support[] political democratization because [they] always ha[ve] been able to dominate the process and determine the outcome." ${ }^{347}$ Moreover, many would argue that the relatively pro-Chinese, accommodationist policies currently favored by the Filipino political elite are not the product of a democratic process but rather, in Suharto-like fashion, have been bought and paid for by wealthy Chinese ${ }^{348}$-again consistent with model outcome three.

Just thirty years ago most Chinese in the Philippines were restricted from citizenship and subjected to sweeping commercial restrictions. ${ }^{349}$ Even today, election leaflets are circulated with slogans such as "The Philippines Is Ours-Do Not Give It To the Chinese!" 350 Hundreds of Chinese are kidnapped (and often brutally murdered) each year because "they have more finances, they have more money than the others." 351 The importance

343. NEHER \& MARLAY, supra note 341, at 54; see also Florian Coulmas, Democracy in Asia?, SwISS REV. WORLD AFF., Apr. 1997, at 4, 5-6 (stating that most voters in the Philippines are uneducated tenant farmers who are dependent on large landowners and who do not have the necessary political awareness to vote for their own interests); The Old Firms, ECONOMIST, May 11,1996 , at S10 (noting that historically land and political influence in the Philippines were vested in a small number of powerful Chinese, Filipino, and Spanish families, whose "wealth and power were rarely diluted").

344. NEHER \& MARLAY, supra note 341 , at 57.

345. Id. at 58 .

346. See id.

347. Id. at 54.

348. See John T. Omohundro, Social Networks and Business Success for the Philippine Chinese, in 1 THE CHINESE IN SOUTHEAST ASIA, 65, 78-79 (Linda Y.C. Lim \& L.A. Peter Gosling eds., 1983) (noting that wealthy Philippine Chinese often establish alliances with powerful Filipino "patron's"); Philippines Targets Marcos Ally's Guam Assets, REUTER ASIAPAC. BUS. REP., Sept. 15, 1993 (describing the investigation of an allegedly corrupt relationship between a Filipino Chinese billionaire and late president Marcos), available in LEXIS, World Library, REUAPB File.

349. See, e.g., Wu \& Wu, supra note 296 , at $53,177-78$.

350. Richburg, supra note 102, at A25.

351. Intimidated Chinese Community Easy Prey for Kidnappers, AGENCE FR.-PRESSE, Apr. 25, 1996, available in LEXIS, News Library, AFP File (quoting a Filipino policeman); see Morella, supra note 103. 
of these episodes should not be exaggerated. Nevertheless, it is too early to conclude that the Philippines is an exception to the model.

\section{Complicating Factors}

This Section will briefly raise some factors that may complicate the model's application to real-world cases. Needless to say, developing country demographics are never as simple as the model suggests. Quite often, no single ethnic group will represent a majority. This is true, for example, of Kazakhstan, which will be discussed below. ${ }^{352}$ Moreover, developing countries almost always comprise more than two ethnic groups, and ethnic rivalries will overlap and compete in complex ways.

In a developing country characterized by ethnic divisions, resentment against a prosperous minority may be overshadowed by much greater animus directed at another ethnic minority, which may or may not be economically dominant. Group dynamics may also be interdependent. Assume, for example, that in country $X$ marketization benefits rival ethnic groups $A$ and $B$ equally. But assume further that historically, $B$ has always been subordinate to ethnic group $C$ in $X$ 's economic hierarchy. If marketization lifts $B$ above $C$, it is possible that members of $A$ will actually consider themselves less well off, despite the improvement of their own position, because of $B$ 's relative success. ${ }^{353}$

Furthermore, as already suggested, it will not always be clear in a given developing country whether an economically dominant minority is marketdominant. This complicating factor, which will be discussed further below, bears profoundly on appropriate policy directions. ${ }^{354}$ In addition, ethnic dynamics are by definition not static. ${ }^{355}$ Thus an ethnic minority that is market-dominant now may cease to be so in the future for a variety of reasons.

Finally, the internal ethnodynamics of a marketizing country may be complicated by the presence of a substantial foreign investor community. As I have explored elsewhere, majority-based resentment and antimarket reactions often have been directed at these groups as well. ${ }^{356}$ Indeed, with some adjustments, the $M D M$ s in the model could, in principle, be foreign investors who prosper visibly and disproportionately under marketization. The focus of this Article, however, is not on these "external foreigners" but

352. See infra text accompanying notes 498,532 .

353. Cf. McAdams, supra note 93 , at 1023,1084 (noting that individuals care deeply about intergroup status).

354. See infra Subsections V.B.3.b, V.C.3.b.

355. See Horowitz, supra note 163, at 113.

356. See Chua, supra note 18, at 263-66. 
on internal ethnic minorities who often come to be regarded by the majority as "foreigners within." 357

\section{E. General Policy Implications of the Model}

Although the policy directions suggested by the model will be highly case sensitive (as Part V will illustrate), it may be useful to highlight here some general insights that the model produces. First and foremost, the model insists that marketizing and democratizing policymakers acknowledge and address the ethnodistributional consequences of their work. In particular, those shaping law and development today should pay careful attention to whether, in any given developing country, marketization favors certain ethnic groups over others. In developing countries in which a market-dominant minority is present, lawyers and policymakers must alert themselves to the strong likelihood that the combined pursuit of markets and democracy eventually will lead either to a retreat from markets, a retreat from democracy, or ethnic eliminationism. The core questions then become: Which of the three outcomes offers the lesser evils? Are there ways to contain and direct such outcomes? From this perspective, ethnically conscious market interventions-which may be viewed as a relatively benign manifestation of model outcome one-may well represent the best realistic alternative. Longer-term strategies would include efforts to study and redress the underlying causes of market dominance in particular cases.

At the same time, it is essential to try to determine whether, in any given country, a market-dominant ethnic minority exists. As already noted, many economically dominant minorities, including so-called "entrepreneurial" groups like the Chinese, may owe their economic success in part to nonmarket factors such as political favoritism or corruption. To the extent that this is the case, marketization may simply create opportunities for disadvantaged groups previously excluded from the market.

Finally, in countries with a market-dominant minority, it is imperative that lawyers and policymakers find ways to disperse effectively and visibly some of the market-generated wealth to the local population. Wealth spreading proposals run counter to the maximum marketization philosophy now in fashion. Measures to disperse share ownership invariably reduce the proceeds received by a privatizing government. More generally, strategies to build a broader-based public participation in the benefits of marketization often have significant short-term efficiency costs. Nevertheless, lawyers and policymakers who continue to ignore the ethnodistributional problems

357. Id. 
of the developing world do so at their peril. With these considerations in mind, we turn now to the model applications.

\section{APPLICATIONS}

This Part will apply the model developed in Part IV to South Africa, Kazakhstan, and Vietnam. This selection of countries rests on a number of considerations. First, the applications will demonstrate that countries with very different cultures, geographies, and historical backgrounds manifest strikingly similar ethnoeconomic and ethnopolitical phenomena. Further, the case studies will demonstrate that the model is robust, applying to all developing states in which a market-dominant minority is present. At the same time, the applications will make clear that the widely varying reasons for different groups' economic dominance will have crucial policy and normative implications. Finally, South Africa, Kazakhstan, and Vietnam are all countries receiving extraordinary attention today from the international business and legal communities. Yet the fact that each is a potential site of collision among the forces of markets, democracy, and ethnicity has been (with the possible exception of South Africa) almost entirely overlooked. Although directions for policy formulation are suggested below, the following applications are not how-to guides. They are merely a first step toward candid analysis of the ethnic dimensions of law and development.

\section{A. South Africa}

\section{Background}

In early 1990 , after decades of brutally enforced apartheid rule, ${ }^{358}$ Frederik de Klerk's Afrikaner-based government took the world by surprise and initiated negotiations for democratization with the African National Congress (ANC), ${ }^{359}$ thus "deliberately embark[ing] on a process that would end white minority rule." ${ }^{360}$ By the end of 1992, a deal had been struck. The

358. For discussions of apartheid, see generally MiCHAEL ATTWELL, SOUTH AFRICA: BACKGROUND to THE CRISIS 92 (1986); AlEX HePPLE, SOUTH AFRICA 13-15 (1966); HOROWITZ, supra note 322, at 11; and MERLE LIPTON, CAPITALISM AND APARTHEID 23 (1985).

359. Organized in 1912 (originally as the African Native National Congress) and legalized in 1990, the ANC was for decades "a liberation movement in exile." Henrik Sommer, From Apartheid to Democracy: Patterns of Violent and Nonviolent Direct Action in South Africa, 19841994, 43 AFR. TODAY 53, 58 (1996); see generally T.R.H. DAVENPORT, SOUTH AFRICA: A MODERN HISTORY 236-37 (4th ed. 1991).

360. Hermann Giliomee, Democratization in South Africa, 110 POL. SCI. Q. 83, 83 (1995). De Klerk's decision, which earned him a Nobel Peace Prize, has been attributed to numerous factors, including the strangling economic effect of international ostracization; the collapse of the former Soviet Union, which had historically backed the ANC; the weakening white demographic base; the increasingly intense anti-apartheid position of Afrikaner church leaders and academics; 
ruling National Party "abandoned the idea of a rotating troika presidency and other extraordinary devices to counteract the will of the majority," and in exchange the ANC accepted a power-sharing system for five years. ${ }^{361} \mathrm{On}$ the economic front, the ANC agreed to abandon its longstanding demands for nationalization and "socialist economics" in return for the National Party's promises "to promote black advancement through affirmative action and [restitution]." 362

Since taking power, the Government of National Unity (first under Nelson Mandela and now under Thabo Mbeki) ${ }^{363}$ has remained committed to undoing the effects of apartheid through land reform, wealth redistribution, the promotion of education, and intensive public works programs, ${ }^{364}$ although many of these programs remain aspirational..$^{365}$ Nevertheless, following a Cabinet shake-up in March 1996, the South African government adopted a new market-oriented national economic strategy (known as the Growth, Employment, and Redistribution policy, or "GEAR") clearly committed to privatization, fiscal restraint, widespread economic deregulation, and full-fledged promotion of foreign investment. ${ }^{366}$

the lesson of Rhodesia (now Zimbabwe); and fear of Afrikaner extinction in the face of growing black education, awareness, and anger. See id. at 84-92.

361. Id. at 97. In June 1996, the National Party, led by de Klerk, withdrew from Mandela's National Unity government and established itself as an official opposition party. See New Constitution Comes into Effect, Marks End of Transition, AGENCE FR.-PRESSE, Feb. 3, 1997, available in LEXIS, News Library, AFP File. The new constitution, which went into effect on February 4, 1997, did away with the power-sharing provisions included in the interim constitution, which had governed South Africa since May 1994. See id.; Lionel Williams, South Africa's New Constitution Takes Effect Today, AFR. NEws, Feb. 4, 1997, available in LEXIS, World Library, AFRNWS file.

362. Giliomee, supra note 360, at 97; see Caspar W. Weinberger, South Africa, FoRBES, Dec. 5,1994 , at 35 .

363. Mbeki took over the presidency of the ANC in December 1997, when Mandela voluntarily stepped down. Mbeki is also deputy president of the state and is expected to succeed Mandela officially when he retires in 1999. See Bryan Pearson, Mbeki Tastes Victory, AGENCE FR.-PRESSE, Dec. 17, 1997, available in LEXIS, News Library, AFP File.

364. See AFrican Nat'L CONGRESS, THE RECONSTRUCTION AND DEvelopment PROGRAMME: A POLICY FRAMEWORK 15-57 (1994); SOUTH AFR. DEP'T OF LAND AFFAIRS, WHTTE PAPER ON SOUTH AFRICAN LAND POLICY (1997).

365. See Gumisai Mutume, South Africa Development: Not Yet Growth with Equity, INTER PRESS SERV., July 17, 1996, available in LEXIS, News Library, INPRES File; Christopher Ogden, The Post-Miracle Phase, TIME INT'L, Sept. 16, 1996, at 46, available in LEXIS, News Library, TIME file. Land reform is one area where significant genuine reforms have begun. See Restitution of Land Rights Act 22 of 1994, 6 JSRSA 2-515; Development Facilitation Act 67 of 1995, 6 JSRSA 2-536 (1997); Communal Property Associations Act 28 of 1996, 6 JSRSA 2-572 (1997); Interim Protection of Informal Land Rights Act 31 of 1996, 6 JSRSA 2-578 (1997); Land Reform (Labour Tenants) Act 3 of 1996, 6 JSRSA 2-63I (1997).

366. See Chris Harmse, Economic Value System: Economic Transition Under Apartheid and the Post Apartheid Government's Proposed New Macro-Economic Strategy, AAMBEELD, Nov. 1996, at 34; South Africa's Ag Minister Briefs Senate, AFr. NEWS, July 31, 1997, available in LEXIS, World Library, AFRNWS file (containing a statement by South African Agriculture Minister Derek Hanekom before the U.S. Senate Committee on Agriculture, Nutrition and Forestry). Since the adoption of GEAR, tensions have heightened between the ANC and the South African Communist Party. Many members of the Communist Party view the free-market 
Although the new South African Constitution has been hailed as one of the most progressive in the world-establishing, among other things, the right to access to adequate housing, health care, food and water, and social security ${ }^{367}$ - the specific form of South Africa's postapartheid economic and social policies remains to be seen.

\section{Satisfaction of Model Conditions}

South Africa easily satisfies most of the model conditions. Condition two (severe ethnic divisions) is almost certainly met; South Africa remains for the moment a nearly paradigmatic case of an ethnically divided society. ${ }^{368}$ Condition three (the presence of a market-dominant minority) is likely satisfied at present as well. The white minority, constituting roughly thirteen percent of the population but owning over eighty-five percent of the country's arable land ${ }^{369}$ and, at least until recently, dominating all of the country's largest conglomerates, ${ }^{370}$ represents an ethnic minority whose economic dominance would be almost certain to persist under free-market conditions in the near to midterm future. Condition four is also satisfied. Notwithstanding the significant (and potentially serious) divisions among black South Africans, ${ }^{371}$ they clearly represent an impoverished majority

orientation of GEAR as a betrayal of the more socialist Reconstruction and Development Programme with which the ANC campaigned in the 1994 elections. See Patrick Bond, Neoliberalism Comes to South Africa, MULTINAT'L MONITOR, May 1996, at 8, 9, 12; William Mervin Gumede, ANC's African Nationalist Core Will Be Under Siege at Mafikeng, SUNDAY INDEP., Nov. 2, 1997, at 5.

367. See S. AFR. CoNST. arts. 26, 27; Williams, supra note 361. The new South African Constitution also contains a Bill of Rights prohibiting discrimination by the state or any person against anyone on the grounds of "race, gender, sex, pregnancy, marital status, ethnic or social origin, colour, sexual orientation, age, disability, religion, conscience, belief, culture, language and birth." S. AFR. CONST. arts. 9(3), 9(4).

368. Ian Shapiro and Courtney Jung have argued that South Africa is not a "fundamentally divided society," pointing out impressive "commonality among [South Africans] of different races" and demonstrating that the extant cleavages in South Africa-whether racial, ethnic, religious, or linguistically based-are "anything but static." Shapiro \& Jung, supra note 163, at 241,244 . This may be true, but it is also true that black and white South Africans generally continue to live and work in a segregated fashion and that rates of intermarriage between the groups remain extremely low. In any event, for the purposes of the model it is sufficient that "racial divisions have played, and continue to play, a profound part in South African politics" and society, as Shapiro and Jung readily concede. Id. at 243.

369. See Mutume, supra note 365; South Africa's Ag Minister Briefs Senate, supra note 366.

370. See Sudarsan Raghaven, Black Owners Take a Piece of a Major South African Firm, Christian SCI. MoNTOR, Sept. 16, 1996, at 7; Mutume, supra note 365; South Africa's Ag Minister Briefs Senate, supra note 366. Historically, English-speaking South Africans dominated the country's most lucrative economic sectors, including banking, insurance, big business, and the mining industry; this generally remains the case today, despite many Afrikaner movements early this century to promote "Afrikaner advancement into key positions of [economic] power and influence." ATTWELL, supra note 358, at 72; see id. at 65-66, 71-72. On the other hand, Afrikaners, many of whom were historically farmers, still own most of South Africa's land. See id. at 64-65; LIPTON, supra note 358 , at 389 tbl.13.

371. See HOROWIT, supra note 322, at 71-75. 
with claims to being the true owners of the nation. ${ }^{372}$ Hence ethnonationalist slogans, such as "Africa for the Africans" and "Africa is Black Man's Country," have persisted since the nineteenth century. ${ }^{373}$

Interestingly, whether South Africa is economically underdeveloped (condition one) is a more complicated question, because apartheid essentially created two economies. Unlike most developing countries, South Africa began the process of industrialization, with the discovery of diamonds and gold, over a century ago. ${ }^{374}$ The country's roads, railways, and hospitals are at least as impressive as those of most developed nations. ${ }^{375}$ Despite the heavy toll of international sanctions, South Africa has a per capita income of about $\$ 3,000$, roughly comparable to an Eastern European country such as Hungary. ${ }^{376}$ By 1992 , over eighty percent of South African whites were in high- or middle-income categories. ${ }^{377}$

The picture is different, however, in black South Africa. The income of approximately seventy percent of black South Africans (fifty-seven percent of the total South African population) falls below the international minimum subsistence level, and over forty percent of the labor force (almost all black South Africans) is unemployed. ${ }^{378}$ More than half of all urban Africans still "live in backyard shacks or squatter settlements." 379 Infant mortality and life expectancy rates for black South Africans are on a par with those of the poorest developing countries. ${ }^{380}$ Predictably, South Africa has one of the least egalitarian wealth distributions in the world, with

372. This is true despite the fact that most Afrikaner families have long-established roots in South Africa. As Professor Horowitz has observed:

Practically every step the Afrikaners took to secure their precarious collective existence had elements of both [nationalist aspiration and racial ideology] embedded in it. The Great Trek north from the Cape in the 1830 s, for instance, was precipitated by the desire to escape some unpleasant features of British rule and threats to cattle and security from Africans on the eastern frontier. The Afrikaners thought they were creating or preserving a nation out of a people threatened with "extinction," particularly by an increasingly powerful British colonialism, but they were simultaneously acting as conquerors of Africans.

Id. at 10 (internal citations omitted).

373. Id. at 13-15.

374. See ATTwELL, supra note 358, at 47-49, 52-53; Background on South Africa, 85 DEP'T STATE BULl. 8, 13 (1985).

375. It was in South Africa that some of the world's first heart transplants were performed, see R.W. Johnson, Whites in the New South Africa, DISSENT, Summer 1996, at 134, 136, and even travel guides wax exuberant about the high quality of South Africa's roads and railways, see, e.g., FODOR'S SOUTH AFRICA at xviii, 2 (1996) (describing South Africa's roads as "immaculately paved" and a ride on the famous Blue Train as "glorious" and "a standard for luxury").

376. See HuNTINGTON, supra note 28, at 312; Giliomee, supra note 360, at 98-99; South Africa's Ag Minister Briefs Senate, supra note 366.

377. Giliomee, supra note 360 , at 99 . During the 1993 GATT negotiations, South Africa was classified as a "developed" rather than "developing" country. Bond, supra note 366 , at 12 .

378. See Giliomee, supra note 360, at 99; Ogden, supra note 365 , at 48 .

379. Giliomee, supra note 360 , at 99.

380. See id. On average in South Africa, whites live 11.5 years longer than blacks. See Mutume, supra note 365 . 
the top five percent of the population consuming more than the bottom eighty-five percent. ${ }^{381}$ This lack of broad economic development makes it plausible to view South Africa as an economically underdeveloped country for purposes of the model.

\section{Analysis}

Assuming that it qualifies as a developing country, South Africa is a pivotal test case for the model. Marketization and democratization are simultaneously taking place in the presence of a resented, market-dominant white minority. Accordingly, despite the remarkably peaceful transition to democratic rule, South Africa's future rests precariously on its ability to confront and address the enormous instability created by the black majority's empowerment in the face of outrageously disproportionate white wealth.

Given South Africa's racial history and persisting ethnoeconomic inequities, the chances of a "democratic miracle" in which voters "become policy- and issue-oriented ... and shed their racial or ethnic concerns" ${ }^{\prime 82}$ is practically nonexistent. Similarly, there is virtually no prospect of a "market miracle," which in South Africa would require fantastic improvement in the black economic sectors (fueled perhaps by booming black corporations $\mathrm{s}^{383}$ and an explosion in the employment of black workers coupled with massive wealth redistribution), such that black South Africans are generally lifted out of poverty. Although it is too early to draw final conclusions, and notwithstanding some impressive achievements, ${ }^{384}$ "the vast majority of black South Africans are no better off economically [today] 366.

381. See Bond, supra note 366, at 8; South Africa's Ag Minister Briefs Senate, supra note

382. Hermann Giliomee \& Charles Simkins, Conclusion, in THE AwKwaRD EMBRACE: DEMOCRACY AND DOMINANT-PARTY RULE IN SOUTH AFRICA, MEXICO, TAIWAN AND MALAYSIA (Hermann Giliomee \& Charles Simkins eds.) (forthcoming 1998) (manuscript at 345, on file with The Yale Law Journal) (hereinafter THE AWKWARD EMBRACE].

383. There is some evidence of corporate empowerment among black South Africans. In the last several years, " 15 black-controlled companies worth more than $\$ 1.7$ billion have been listed on the Johannesburg Stock Exchange, up from none in 1993." Ogden, supra note 365; see also Paul Richardson, S. Africa Privatisation Seen Boosting Black Business, REUTERS, Sept. 4, 1996, available in LEXIS, News Library, WIRES File (describing the progress of black businesses). It is unclear, however, how deep this black empowerment goes. Critics have charged that "white captains of industry have simply created a tiny black superelite to serve as a buffer" between the white business community and the black-controlled government. Dele Olojede, Building a Better South Africa, NEwSDAY, June 6, 1997, at A6.

384. According to the government, since 1994 "more than one million homes have been electrified and water has been reticulated to one million people." South Africa's Ag Minister Briefs Senate, supra note 366. 
than they were three years ago." 385 Further, "the apartheid-era ghettos of the past" are still swelling by roughly a million people a year. ${ }^{386}$ If anything, as many commentators have warned, "reliance on the market at the expense of government direction and intervention," while delighting domestic and international bond traders, will very probably exacerbate the plight and frustration of the great majority of black South Africans in the near to midterm. ${ }^{387}$ Meanwhile, expectations among the black majority are dangerously unrealistic. ${ }^{388}$

The model predicts that, absent a stunning transformation in black South African economic prospects, powerful pressures will push South Africa toward one or more of the following possible outcomes: an ethnically fueled antimarket backlash, actions aimed at eliminating the white population, or a retreat from democracy. The following discussions very briefly suggest how the model predictions are beginning to play out in the South African context.

\section{a. Antiwhite, Antimarket Backlash}

The aggressive and popular efforts by the South African government to attract foreign investment and promote trade liberalization have prompted many international commentators to assert that the commitment to unfettered markets "has never been as dominant in South Africa as it is today." ${ }^{389}$ Although the South African government has little incentive to dispel such a perception among the international community, this is not entirely accurate. While vigorously courting international markets on the one hand, the South African government is on the other hand intervening in South Africa's internal markets in significant, ethnically motivated ways, consistent with the model's first outcome.

For example, the government is in the process of adopting, along with land restitution policies, certain restrictions on the use and alienability of

385. Ogden, supra note 365; see also Kurt Shillinger, Mandela Passes ANC Torch; Successor Aims for Development, BOSTON GLOBE, Dec. 21, 1997, at A2 (noting that employment levels in South Africa have declined over the past 18 months).

386. Ogden, supra note 365.

387. Bond, supra note 366 , at 8 .

388. In a pre-1994 election poll, $81 \%$ of black South Africans "said that they expect[ed] the new government to make sure that 'people like me can live like most whites." Hermann Giliomee \& Charles Simkins, The Dominant Party Regimes of South Africa, Mexico, Taiwan and Malaysia: A Comparative Assessment, in THE AWKWARD EMBRACE, supra note 382 (manuscript at 1,24$)$.

389. Bond, supra note 366, at 9; see also Newton Kanhema, Mbeki Predicts Bright Economic Future for South Africa, AFR. NEWS, Feb. 4, 1998, available in 1998 WL 6607901 (noting that Deputy President Thabo Mbeki is "increasingly optimistic" about South Africa's ability to attract foreign investment); South Africa's Ag Minister Briefs Senate, supra note 366 ("[T]rade and investment promotion are increasingly important thrusts of our Government."). 
rural, and thus principally Afrikaner, land. ${ }^{390}$ Specifically, the draft Extension of Tenure Security Bill

proposes that where people live on rural land with the consent of the owner or person in charge, they may only be evicted if two criteria are met. First, the occupier's right of occupation must be lawfully terminated-for example, through a fair dismissal or the expiry of a contract. Second, the court must decide whether (and if so when) eviction is justified.

....

At present, the law allows a land-owner to dump on the side of the road people who have lived on the land for decades, who have nowhere else to go, and who have done nothing to cause or justify an eviction. Most reasonable people would agree that this is not just. The law must be changed. ${ }^{391}$

The proposed restrictions, which also cover black tribal land but which the government concedes would almost exclusively affect whites, ${ }^{392}$ have generated bitter opposition from some white landowners, who claim that the draft bill "boils down to blatant discrimination. It establishes completely new rights at the expense of existing property rights." ${ }^{393}$

At the same time, the South African government is expected in the near future to pass a national water bill radically altering the existing structure of water ownership and access. As described in the White Paper on a National Water Policy for South Africa, during the apartheid regime "access to water for use in agriculture [was] even more skewed than access to land." 394 For decades, riparian laws (tying use of water to ownership of land) were enforced, and dams, pumping stations, and pipelines were built to divert South Africa's water to "a privileged minority of private land owners." 395

390. See Explaining the Rationale Behind the Bill, LAND INFO (Communications Directorate, Dep't of Land Aff., Pretoria, S. Afr.), Feb.-Mar. 1997, at 4, 4-5.

391. Id. The draft Extension of Tenure Security Bill was proposed by the South African Department of Land Affairs after an extensive multi-party consultation process commencing in July 1996 . See id. at 3-4.

392. In theory, the draft bill applies to all rural land owned by whites or blacks. According to the government, however, principally white farmers will be affected, because of the following "paradox":

Many more people live [on rural black tribal land] than on [white] commercial farms.

But there are very few evictions from tribal land. Although they are the most crowded areas of the country ... they continue to give shelter to people evicted from "white" land. They suffer the results of eviction-they are seldom the cause of eviction. The reason is that people in these areas live according to an ethic which accepts that you Id. at 5 . cannot willy-nilly dump people with nowhere to go.

393. Id. (quotation marks and citation omitted).

394. DEPARTMENT OF WATER AFF. \& FORESTRY, WHITE PAPER ON A NATIONAL WATER POLICY FOR SOUTH AFRICA 12 (Apr. 1997).

395. Id. at 14 . 
As a result, between twelve and fourteen million black South Africans are currently "without access to safe water and over 20 million without adequate sanitation." 396

The proposed water law would abolish the existing riparian system and effectively nationalize "South Africa's scarce water resources" with the government serving "as custodian of the 'public trust." ${ }^{397}$ Current water users would then be required to apply to the government for a license in order to continue their existing water use. ${ }^{398}$ Water users would pay for their use of water according to a variable pricing system. ${ }^{399}$ An exception would be made for water "for basic human needs," which would be provided free of charge. ${ }^{400}$ Although water resources are often state-owned and statedistributed even in highly marketized economies, the proposed nationalization and redistribution of water in South Africa would negatively affect whites (principally Afrikaners) almost exclusively for the benefit of nonwhites. Indeed, the proposed water reforms are aimed explicitly at reversing the "inefficient racial spoils system" of the apartheid era, which eroded significantly "both the right to dignity and the right to life amongst the Black majority." 401

Finally, the recently released Employment Equity Bill (substantially patterned on the Malaysian affirmative action model) is expected to come before Parliament this year. ${ }^{402}$ Although the proposed law does not impose quotas for black representation in the workplace, it "requires every business to have an affirmative action plan" directed at "inclusion in the economy of those sections of the population previously excluded." ${ }^{403}$ The bill, which many say "opens up a vast sphere of state intervention," is "vehemently"

396. Id. at 9 .

397. Id. at 14 (citation omitted). The government's current position is that the proposed restructuring of South Africa's water system, which aims at "redress[ing] the results of past racial discrimination," will not require compensation to existing water users under the property clause of the new South African Constitution. Id. at 8. For an excellent historical and philosophical discussion of the property clause of the South African Constitution, see generally Andre J. Van der Walt, Property Rights, Land Rights, and Environmental Rights, in RIGHTS AND CONSTITUTIONALISM: THE NEW SOUTH AFRICAN LEGAL ORDER 455 (Dawid van Wyk et al. eds., 1995).

398. See DEPARTMENT OF WATER AFF. \& FORESTRY, supra note 394 at 4,17 . Thus, "[w]ater use allocations will no longer be permanent" but instead will endure for a reasonable period. Id. at 4. "If no application is made for the registration of an existing water-use, it will be assumed that that use has been abandoned ...." Id. at 18 .

399. See id. at 23.

400. Id.

401. Id. at 7 .

402. See R.W. Johnson, Pretoria to Impose Affirmative Action on Businesses, TMES (London), Sept. 8, 1997, at 14; Christo Volschenk, Affirmative Action Law Coming, CAPE TIMES, Sept. 5, 1997, at 15.

403. Volschenk, supra note 402 , at 15 . The proposed legislation threatens heavy penalties for noncompliance. See Affirmative Action the Only Way for South Africa: Mandela, AGENCE FR.PRESSE, Feb. 6, 1998, available in LEXIS, News Library, AFP File. 
supported by the black middle class and opposed by the business community. ${ }^{404}$

To varying degrees, all these measures represent derogations of freemarket policies-whether by curtailing the conventional bundle of rights of landowners, by nationalizing resources, or by restricting employment decisions. They are also all ethnically driven, even if occasionally drafted in formally race-neutral language. If, however, the economic situation of the black African majority does not improve significantly in the near future, the retreat from market policies in South Africa may well begin to take a more extreme form.

Nationalization and expropriation were for years-and until quite recently-a central plank of the ANC. ${ }^{405}$ While it is currently popular to view nationalization as a phenomenon of the past, as I have discussed above and elsewhere, in the developing world waves of privatization and free-market euphoria have repeatedly given way to renationalization programs expressly targeting wealthy ethnic minorities. ${ }^{406}$ In South Africa, privatization initiatives over the last several years have met with significant opposition, principally from the influential trade unions. ${ }^{407}$ The politically powerful Congress of South African Trade Unions (COSATU) continues to advocate "a bigger, not smaller, public sector to satisfy the country's huge social and economic needs." ${ }^{408}$ COSATU has also ridiculed big business efforts to transfer wealth to blacks as "no more than corporate camouflage which retains power and control in the small group of shareholders and their directors." ${ }^{409}$ Support for nationalization among black South Africans remains substantial. ${ }^{410}$

404. Johnson, supra note 402 , at 14 .

405. See ATTWELL, supra note 358, at 203; Giliomee, supra note 360, at 97; Andi Spicer, ANC Mining Industry Plans Spark Concern, INTER PRESS SERV., Mar. 25, 1994, available in 1994 WL 2583793; South Africa: ANC Rethink on Nationalisation, AFR. ECON. DIG., Nov. 19, 1990, available in LEXIS, World Library, TXTAFR File. Indeed, the Freedom Charter, still "the closest thing to a statement of principles by non-white South Africa," specifically calls for the transfer of the country's "mineral wealth," banks, and "monopoly industry" to "the people as a whole." ATTWELL, supra note 358, at 90 (quoting from the Freedom Charter). The Freedom Charter was drafted in 1955 by the ANC and other nonwhite groups. After decades of "semiobscurity," recent events in South Africa have given the Charter renewed status. See id.

406. See Chua, supra note 18; supra text accompanying notes 248-262.

407. See A Labor Perspective on the South African Economy, MULTINAT'L MoniTor, May 1996, at 10, 10; Bernard Simon, Privatisation, FIN. TmES, Oct. 22, 1997, at 4. But see Bongiwe Mlangeni, South Africa: Privatization of SAA in the Pipeline, INTER PRESS SERV., Oct. 29, 1997, 1997 WL 13257416 (reporting that airline worker unions in South Africa favor the privatization of South African Airways and believe that job losses will not be extensive).

408. Simon, supra note 407, at 4; see also Bond, supra note 366 , at 14 (stating that COSATU has advocated job creation by reorienting the economy to meet basic needs production). COSATU has also called for "more cautious engagement with the world economy." Bond, supra note 366, at 14.

409. Bond, supra note 366 , at 14.

410. See Giliomee \& Simkins, supra note 388 (manuscript at 29); Gumisai Mutume, Thumbs Down for Privatization, INTER PRESS SERV., July 1, 1997, available in 1997 WL 7076286. 


\section{b. Eliminationist Strategies}

At the same time, as long as terrible black poverty and extraordinary white wealth persist, one would also expect to see the beginnings of antiwhite eliminationism. Although the government has not wavered from its commitment to a multiracial democracy, ${ }^{411}$ there long has been in South Africa an influential, exclusionary strand of African nationalism, according to which indigenous Africans are the sole legitimate owners of the soil. ${ }^{412}$ As late as 1989, participants at the inaugural meeting of the Pan-Africanist Movement chanted, "One settler-one bullet!" ${ }^{413}$ At the moment, these Africanist movements generally are perceived as a fringe phenomenon, supported by a relatively small percentage of the population. ${ }^{414}$ Moreover, despite the recent crime wave in South Africa, ${ }^{415}$ there have been remarkably few reports of explicitly antiwhite violence. Nevertheless, there are plenty of signs already of black backlash against white religions, ${ }^{416}$ language, ${ }^{417}$ codes of morality, ${ }^{418}$ teachers, ${ }^{419}$ pedagogy, ${ }^{420}$ television, ${ }^{421}$ and

Winnie Madikizela Mandela, who still has adoring populist followers, continues to attack the government's economic gradualism and instead champions more immediate delivery of economic and social benefits. See Gumede, supra note 366, at 5. Mrs. Mandela recently declined to run for the post of ANC deputy president. See Alec Russell, Winnie Mandela Bows out of Race for Key ANC Post, DALY TElEGRAPH (London), Dec. 18, 1997, at 17.

411. See Michael Collins, Grandfather and Leader, Mandela Speaks, UPI, Apr. 23, 1994, available in LEXIS, News Library, UPI File (quoting Mandela's call for "national unity"); Russell, supra note 410, at 17 (quoting newly-elected Mbeki as stating that "[d]emocracy does not threaten white people in this country").

412. See HoROWITZ, supra note 322 , at 13-15. As early as the 19 th century, a movement had begun to "keep 'Africa for the Africans." Id. at 13. In the 1950s, "[t]o the ANC's declaration in the Freedom Charter of 1955 that 'South Africa belongs to all who live in it, black and white ....' the Africanists rejoined in their journal that ' $[t]$ he African people have an inalienable claim on every inch of the African soil." Id. at 13-14 (internal citation omitted). In the seventies, "Black Consciousness" leaders repeatedly declared that South Africa "belongs exclusively to Blacks." Id. at 15. Even among Africanists, however, there is disagreement over the ultimate place of whites in South Africa. See id. at 6, 15.

413. Id. at 14 .

414. On the other hand, commentators have suggested that "the ANC has increasingly abandoned its 1994 election appeal of nonracialism for an explicit call to African solidarity." Giliomee \& Simkins, supra note 382 (manuscript at 344 ).

415. See Judith Matloff, Murderous Society? High Crime Rate in South Africa Cuts Across Racial, Economic Lines, CHRISTIAN SCI. MONITOR, Nov. 13, 1995, at 7.

416. Dali Tambo, the host of a popular television show, criticized Afrikaner Christianity as homophobic, "primitive, Calvinist and Victorian, a spiteful, angry, intolerant culture. ... And totally hypocritical." Bill Keller, Apartheid's Gone, and Anything Goes, N.Y. TMMES, Dec. 28, 1994, at A7; see also J.P. Peires, Suicide or Genocide? in HISTORY FROM SOUTH AFRICA: ALTERNATIVE VISIONS AND PRACTICES 34-35 (Joshua Brown et al. eds., 1991) (discussing Xhosa suspicions about white missionaries) [hereinafter HISTORY FROM SOUTH AFRICA].

417. Strikingly, black hostility has been directed almost exclusively against Afrikaans (the "language of the oppressor"), as opposed to English, which is generally accepted as the "business" language. See Rohan Minogue, Afrikaners in Rare Unity over Their Language, DEUTSCHE PRESSE-AGENTUR, Aug. 5, 1994, available in LEXIS, NEWS Library, ARCNIVS File; Patrick McDowell, Language Battle Heats up as TV Switches Tongues, ASSOC. PRESS, Feb. 4, 1996, 1996 WL 440998. 
the "White way of life" generally. ${ }^{422}$ Perhaps as a result, " [m]any suburban whites live in jail-like homes guarded by vicious dogs, razor wire, and armed security guards summoned by panic buttons." ${ }^{423}$ Thus, despite the government's assurances, ${ }^{424}$ roughly 18,000 whites, many of them affluent and educated, leave the country each year. ${ }^{425}$ Although the significance of isolated incidents should not be exaggerated, it remains telling that a leading ANC official, stopped last November for driving while intoxicated, could tell the policeman: "When Mandela dies, we will kill you whites like flies." ${ }^{426}$ It takes little imagination to envision the emergence of charismatic African leaders espousing eliminationist policies. If not outright violence against whites, these policies might include laws targeting the public use of Afrikaans, suppressing white schools and churches, and otherwise treating whites as cultural or political enemies within the state. ${ }^{427}$

418. Black South Africa has reacted in many ways to the "intolerant" and "hypocritical" Afrikaner morality code, for example, by legalizing abortion, homosexual activity, and sexually explicit films and magazines. Keller, supra note 416, at A7.

419. See Ingeborg Lichtenberg, S. African Black Pupils Vow to Evict White Teachers, REUTERS, Aug. 24, 1995, available in LEXIS, News Library, WIRES File; Gumisai Mutume, Radical Students Want White Teachers out, INTER PRESS SERV., Aug. 3, 1995, available in LEXIS, News Library, INPRES File.

420. See Melanie Walker, History and History Teaching in Apartheid South Africa, in HisTORY FROM SOUTH AFRICA, supra note 416, at 268, 269; Anton Christen, South Africa After Apartheid, SwISS REV. WORLD AFF., May 1996, at 6, 7 (noting recent demands that the University of Witwatersrand renounce its "superfluous, colonialistic and alienating" image as a liberal, English-speaking university).

421. See, e.g., C.A. Hamilton, A Positional Gambit, in HISTORY FROM SOUTH AFRICA, supra note 416 , at $288,293$.

422. There is a small but growing movement, for example, to introduce Ubuntu-" the traditional Black African sense of the collective, according to which a person is a true human being only through and with others"-into the workplace, university education, and business management practices. See Christen, supra note 420 , at 7 . In response, numerous Afrikaner-based organizations have sprung up to fight for "the preservation of Afrikaner culture." Gumisai Mutume, Afrikaners Try to Keep Flag Flying, INTER PRESS SERV., Jan. 26, 1996, available in LEXIS, News Library, INPRES File.

423. Matloff, supra note 415 , at 7.

424. Like Mandela before him, Mbeki advocates "a non-racial society [that] is in the interests of both black and white." Pearson, supra note 363. At the same time, Mbeki has publicly warned whites that unless they "voluntarily" share their wealth, "they could face 'race riots' in three to five years." Id.

425. See Johnson, supra note 375, at 135; Fredric Chambon, A World Turned Upside Down, WORLD PRESS REV., Oct. 1996, at 18.

426. David J. Lynch, A Wary Nation Looks to a Time of Transition, USA TODAY, Dec. 15, 1997, at 17A; Mandela's ANC Fuelling Racial Tension in S. Africa, Opponents Say, AGENCE FR.PRESSE, Nov. 9, 1997, available in LEXIS, News Library, AFP File. The ANC "apologised unreservedly for [the official's] alleged remarks." Senior ANC Official Faces Inquiry on Racism Charges, AGENCE FR.-PRESSE, Nov. 14, 1997, available in LEXIS, News Library, AFP File. It is also worth noting that in 1993, Peter Mokaba - who today is included in President-to-be Mbeki's "inner circle"-led ANC Youth members in singing "Kill the Boer" and a month later urged blacks to "direct [their] bullets against de Klerk." Brendan Boyle, ANC Youth Leader Says Turn Guns on De Klerk, REUTERS, Aug. 12, 1993, available in LEXIS, News Library, WIRES File; see also Gumede, supra note 366 , at 5 .

427. See Gilbert A. Lewthwaite, African Nationalism Debate Is Growing in South Africa, BALT. SUN, June 25, 1997, at 1A. 


\section{c. Antidemocracy Backlash}

A retreat from democracy in South Africa could take at least three different forms. First, the white minority could reseize power militarily and either restore apartheid nationally (highly unlikely) or establish a prosperous white homeland in South Africa. ${ }^{428}$ Second, an ethnonationalist African leader could overthrow the current market-friendly, accommodationist, democratic regime. ${ }^{429}$ Finally, an accommodationist government could continue liberal, pro-market policies by defying increasingly hostile majority will and suppressing electoral competition. Along these lines, several points about South Africa's current political structure are worth raising.

To begin with, South African parliamentary elections are conducted wholly by proportional representation according to a party-list method. Thus, in order to be elected to Parliament (which requires a high ranking on the party list), local politicians must be well regarded among the leaders of the party hierarchy ${ }^{430}$ This national party-list method may give the current ANC leadership a means of sifting out ethnonationalist extremists in a way that would not be possible with a constituency-based representation system (although obviously the party list in the end cannot be at complete odds with popular support). In addition, many political analysts in South Africa argue that undemocratic internal political procedures of the ANC have allowed the current leaders to sweep away all formidable extremist opposition within the party structure. ${ }^{431}$ Some commentators fear that the excessive dominance of the ANC may well turn South Africa into a variant of a one-party dominant regime similar to those historically in place in countries like Mexico or Taiwan. ${ }^{432}$ On all of these points, further inquiry is required.

428. See Johnson, supra note 375, at 137. Calls by Afrikaner separatists for the establishment of a "Volkstaat" or Afrikaner homeland-technically permissible under the new constitutionhave not diminished. See Christen, supra note 420, at 6; Michael Hamlyn, New Constitution a Human, Liberal and Comprehensive Document, NEw STRAITS TIMES, May 9, 1996, at 1.

429. In recent years, the Pan African Congress and COSATU have become increasingly critical of South Africa's economic and social direction. See Lewthwaite, supra note 427; Mandela Faces Friction, BALT. SUN, July 9, 1997, at 12A. One black African labor leader recently suggested that "the ANC's soul [may] already [be] too far lost, given the policies it has adopted since coming to power." A Labor Perspective on the South African Economy, supra note 407 , at $1 \mathrm{~A}$.

430. See Giliomee \& Simkins, supra note 388 (manuscript at 17-18, 44).

431. According to Professors Giliomee and Simkins, recent developments in South Africa indicate a legislature that is neither strong nor independent and "leadership intolerance of any criticism of an ANC minister by representatives of the party regardless of the charges levelled against him or her." Id. (manuscript at 41 ).

432. See Giliomee, supra note 360, at 103-04. For an illuminating comparative analysis, see generally THE AWKWARD EMBRACE, supra note 382. 


\section{Directions}

None of these warnings is new for South Africa. On the contrary, most of these troubling outcomes have already been prophesied, with varying degrees of doomsaying, in the burgeoning literature on post-apartheid South Africa ${ }^{433}$ The model's distinctive contribution here lies in the counsel it offers to lawyers and policymakers participating in South Africa's transformation. As already noted, prevailing law and development orthodoxy effectively presumes that the cures currently prescribed for economic and political underdevelopment-markets and democracy-will also cure ethnic conflict. By contrast, the model insists that lawyers and policymakers recognize that marketization and democratization-to the extent that they are successful, to the extent that they do just what they are supposed to do-will, in countries like South Africa, in fact tend to catalyze ethnic conflict in a highly determinate and predictable fashion. Markets and democracy cannot be regarded as solutions to the dangers of ethnic strife in a country like South Africa. They are, at least in the short and midterm, part of the problem.

What then is the solution? One position is that the best way to address the dangers of racial strife is through race neutrality. On this view (which has a familiar United States counterpart) ${ }^{434}$ race-based interventions necessarily mirror the race-based apartheid regime, invariably perpetuating destructive racial politics and racialist thinking. The policy thrust of this view is that South Africa should address its problems not through ethnically based interventions into the marketplace, but rather through race-neutral progressive taxation, social welfare policies, and the other conventional components of the liberal activist state, which, over time, will be the best corrective for economic imbalance and racial strife.

This view, which perhaps seems appealing from afar, runs a tremendous risk of blindness-almost of willful blindness-to South African realities. Post-apartheid South Africa already has progressive

433. See, e.g., Janet Cherry, Development, Conflict and the Politics of Ethnicity in South Africa's Transition to Democracy, 15 THIRD WoRLD Q. 613, 628-29 (1994); Giliomee \& Simkins, supra note 388 (manuscript at 29-30); Wilmot James \& Daria Caliguire, Renewing Civil Society, J. DEMOCRACY, Jan. 1996, at 56, 60; Johnson, supra note 375, at 135; Courtney Jung \& Ian Shapiro, South Africa's Negotiated Transition: Democracy, Opposition, and the New Consitutional Order, 23 POL. \& SOC'Y 269, 297-99 (1995).

434. See, e.g., NATHAN GLAZER, AFFIRMATIVE DISCRIMINATION: ETHNIC INEQUALITY AND PUBLIC POLICY 168-95 (1975) (arguing that affirmative action in the United States stigmatizes minorities and entrenches invidious stereotypes); Antonin Scalia, Commentary, The Disease as Cure, 1979 WASH. U. L.Q. 147, 154 (stating that the U.S. affirmative action system "is based upon concepts of racial indebtedness and racial entitlement rather than individual worth and individual need; that is to say ... it is racist"). See generally Jed Rubenfeld, Affirmative Action, 107 YALE L.J. 427, 444 (1997) (laying out the now familiar "move[s] and countermove[s] in the colorblindness debate"). 
taxation, ${ }^{435}$ and the government is probably doing as much as it currently can with respect to social welfare programs. Conceivably, in the best of worlds, race-neutral policies might be the optimal approach to South Africa's difficulties over a long stretch of time. But when it is remembered that the townships today are not shrinking but growing-at a rate of a million black Africans a year ${ }^{436}$-pursuing the "best of all worlds" solution becomes a luxury South Africa is unlikely to be able to afford.

If in another five or ten years it remains the case (as it quite possibly will) that the "vast majority of Blacks are no better off than they were," 437 there is a very real danger that a black majority will find it intolerable to live under a "race-neutral" political and economic system whose reality is massive black immiseration and massive white wealth. Obviously, in a country as dependent on global markets as South Africa, ${ }^{43}$ "the government cannot... violate rights, particularly property rights, without incurring serious financial and economic costs." ${ }^{439}$ Nevertheless, the notion that the black majority will act as rational, long-term wealth-maximizers, cognizant that antiwhite measures may discourage foreign investment, is unrealistic. Indeed, from the point of view of township inhabitants, unlikely to benefit from marketization and globalization within their lifetimes, extremist measures might in fact be "rational." 440 In any event, whatever the merits of a race-neutral approach in a country like the United States, it may be in South Africa the best recipe for racial violence, expropriation, and an eventual collapse of democracy.

At the same time, it should not be overlooked that the recently adopted South African Constitution gives protections to minorities that in principle would guard against confiscatory practices and racial eliminationism. ${ }^{4+1}$ In comparison with most developing countries, South Africa is unusual in having an independent constitutional court that is generally perceived to be politically legitimate. ${ }^{42}$ Such an institution gives South Africa a potential line of defense against ethnonationalist abuses that is generally unavailable in the developing world. ${ }^{443}$ Nonetheless, it is surely naive to expect a

435. See Charles Simkins, The New South Africa: Problems of Reconstruction, J. DEMOCRACY, Jan. 1996, at 82, 93.

436. See Ogden, supra note 365 .

437. Id.; see Shillinger, supra note 385 , at A2.

438. Imports and exports currently represent more than $60 \%$ of South Africa's gross domestic product. See Giliomee \& Simkins, supra note 388 (manuscript at 24).

439. Id. (manuscript at 40).

440. An excellent recent exploration of the relationship between political backlash and economic efficiency can be found in Roe, supra note 92, at 218-21. Professor Roe writes that "in some systems, politics may lash back," $i d$. at 218 , and "disrupt otherwise efficient [economic] arrangements. ... [A]nd this backlash potential complicates economic analysis." Id. at 217-218.

441. See, e.g., S. AFr. CONST. arts. 9, 11, 12, $20,25$.

442. See Giliomee \& Simkins, supra note 388 (manuscript at 39).

443. See Vincent T. Maphai, The New South Africa: A Season for Power-Sharing, J. DEMOCRACY, Jan. 1996, at 67, 80. 
constitutional court only a few years old to stand against an incited black majority-particularly if that court has been insistent on race neutrality. Zimbabwe also had a longstanding tradition of constitutionalism, and ethnonationalist nationalizations are occurring there even today. ${ }^{444}$

If the model applies to South Africa, the somber reality is that the nation will almost certainly be forced down one (or more) of the three paths discussed above: a retreat from democracy, an ethnically targeted retreat from free-market policies, or attempts to eliminate the white population. From this point of view, carefully tailored, ethnically conscious market interventions might well be the best of the "second best" solutions available to South Africa. For example, however distasteful they may be to some Westerners, ethnically based employment preferences might be the best way of forestalling full blown nationalization or antiwhite violence. Indeed, such initiatives may be responsible in part for the success South Africa has had thus far in maintaining racial accommodation.

It is far from clear, however, that the current measures will be sufficient to resist the powerful antiwhite, antimarket pressures that undoubtedly will intensify unless the government finds ways to spread market-generated wealth rapidly, visibly, and significantly to the black African population. If the model is correct, the South African government should be championing broad-based black participation in the marketization process, even at the expense of short-term growth. It should be working to disperse the benefits of privatizations, international joint ventures, and the like to the great majority of blacks who continue to live in the country's grossly impoverished rural areas or urban slums. This might be achieved through subsidies and loans or, more controversially, through quotas or ownership restrictions. ${ }^{45}$ Unfortunately, the government has abandoned many of its more ambitious redistributive proposals over the last few years, including programs to provide low-cost housing, promote worker ownership, and make cheap credit widely accessible. ${ }^{446}$

Yet even these kinds of interventions-already opposed by many in the business community on grounds that they "will balloon the government deficit" ${ }^{47}$-may not be enough to assure the sustainability of free-market democracy in South Africa. It may be that the only way to dismantle the conditions of ethnoeconomic violence in South Africa is through more radical transformations, perhaps along the lines of Roberto Unger's visionary program to reimagine the institutional arrangements of markets

444. See source cited supra note 262.

445. See Chua, supra note 18, at 293. This approach has some precedent in Latin America, where "popular capitalism" initiatives have been tried on a limited basis with considerable success. Id.

446. See Bond, supra note 366 , at 10-12.

447. Id. at 12. 
and democracy. ${ }^{448}$ Other radical, innovative reforms-for example, Andre van der Walt's challenge to the supposed race neutrality of the entire "common law ownership paradigm" 449 - have also been proposed.

Finally, along with ethnically conscious retreats from the market, there might also be room for ethnically conscious interventions in the democratic process. A growing literature, for example, explores the possibility of adjusting districting rules and vote counting rules-in a way consistent with the principle of one man, one vote-to ameliorate ethnic tensions. ${ }^{450}$ In addition, some scholars and policymakers have advocated as important for preserving ethnic stability various "power-sharing" devices to "counteract the will of the majority" and to ensure protection of the white minority. ${ }^{451}$ Although these avenues are worth considering, the thrust of the model is that if South Africa's extreme ethnoeconomic imbalances are not vigorously addressed, the prospects of creating interracial coalitions by tinkering with the democratic process almost certainly will be dismal.

\section{B. Kazakhstan}

\section{Background}

Kazakhstan is a large country-larger than all of western Europe-with a small population. ${ }^{452}$ It is prodigiously rich in oil, gas, and mineral deposits. ${ }^{453}$ Kazakhstan is also landlocked, sandwiched between Russia and China, with Iran, Pakistan, and war-torn Tajikistan to the south. ${ }^{454}$

448. See UNGER, supra note 2 (manuscript at 108-208).

449. A.J. van der Walt, Property Rights and Land Policy: Some Remarks on Land Reform in South Africa 27 (1998) (unpublished manuscript, on file with The Yale Law Journal). Van der Walt advocates a shift "towards the creation of new, needs-driven rights that do not fit into [the traditional] paradigm." Id.

450. See, e.g., HoROWTZ, supra note 10, at 628-52 (discussing the roles that different electoral systems have played in fostering or retarding ethnic tensions).

451. Thomas Koelble \& Andrew Reynolds, Power-Sharing Democracy in the New South Africa, 24 POL. \& SOC'Y 221, 221 (1996); see HERIBERT ADAM \& KOGLA A. MOODLEY, SOUTH AFRICA WITHOUT APARTHEID: DISMANTLING RACIAL DOMINATION 207, 242-43 (1986); HOROWITZ, supra note 322, at 137-39; AREND LIJPHART, POWER-SHARING IN SOUTH AFRICA 69, 80-81 (1985). In two influential essays, Jung and Shapiro opposed the inclusion of mandated power-sharing arrangements in the permanent South African Constitution, arguing that such arrangements tend to discourage effective opposition institutions, which are "basic ingredients of a viable democracy." Jung \& Shapiro, supra note 433, at 270; see Shapiro \& Jung, supra note 163, at 238-39. As noted earlier, the new South African Constitution actually abandoned the power-sharing provisions included in the interim constitution. See supra note 361 .

452. See Michael Mandelbaum, Introduction to CENTRAL ASIA AND THE WORLD 6 (Michael Mandelbaum ed., 1994). Kazakhstan's population as of 1994 was roughly 17 million, about six percent of the United States'. See CHINN \& KAISER, supra note 127, at 187 (citing statistics on Kazakhstan); CIA, THE WORLD FACTBOOK 1994, at 210 (1994) (discussing Kazakhstan).

453. In addition to immense oil and gas reserves, Kazakhstan is the major source of nonferrous metals (including zinc, lead, titanium, magnesium, and chromium) in the former 
The consensus is that the Kazakh people formed in the mid-fifteenth century by breaking away from Uzbek tribes. ${ }^{455}$ By the late seventeenth century, Kazakh hordes controlled most of what is now Kazakhstan. ${ }^{456}$ In the early nineteenth century, Russians began settling in the northern Kazakh steppe. The two cultures clashed head-on. The Kazakhs were "halfsavage" ${ }^{457}$ nomads, defined by their migratory, livestock-breeding way of life. ${ }^{458}$ Russian farming settlements thwarted Kazakh migration by monopolizing potential pasturelands and precious water sources, provoking Kazakh resentment and raids. ${ }^{459}$

With Russian expansion of trade in the Middle and Far East, pacification of the Kazakh steppe became an imperial priority. ${ }^{460}$ By the 1850 s, all of present-day Kazakhstan had been conquered. ${ }^{461}$ Prerevolutionary Kazakhstan was a cauldron of discontent, marked by widespread seizure of land by Russian authorities, ${ }^{462}$ forced sedentarization of Kazakhs, ${ }^{463}$ Kazakh revolt and rebellion, ${ }^{464}$ and fierce Russian retaliation in which thousands of Kazakhs were killed or forced into exile. ${ }^{465}$

After the Russian Revolution, first Lenin and then Stalin adopted a "divide and conquer" strategy in Central Asia ${ }^{466}$ Hoping to counteract the rise of nationalism and Islamic fundamentalism in the region, ${ }^{467}$ Moscow in

Soviet Union and has some of the largest iron and gold deposits in the world. See Gordon Elliot, Kazakhstan, Nazarbayev, Foreign Investment \& Oil, 53 LA. L. REv. 1243, 1250 (1993).

454. See CIA, supra note 452, at 209; Mandelbaum, supra note 452, at viii.

455. See OlCOTT, supra note 120 , at 3,8 . The Kazakhs broke away from the Uzbek khanate after the Uzbeks were defeated by the Mongols. See id.

456. See id. at 11-12. Although divided into three hordes (federations or unions of tribes, unrelated by blood), the Kazakhs shared a common language, culture, and economy and viewed themselves as one people. See id.

457. Id. at 75 (citation omitted).

458. See id. at 18. The Kazakhs grazed their herds on "common pasturelands over which tribes had usage rights but did not own." Id. Thus, to the Kazakhs, "land had no intrinsic value"; wealth was based on the size of one's herd, not acreage. Id.

459. See id. at 18.

460. See id. at 57-58. Since "trading caravans to Persia, China, India, and the Central Asia khanates had to pass through the Kazakh territories," Russia wanted to safeguard these lucrative trading routes and to strengthen their defensive line. Id.

461. See GREgory Gleason, THE CENTRAL AsIan STATES: DisCovering INDEPENDENCE 33 (1997); cf. Olcott, supra note 120, at 72-73 (describing Russian conquests through the first half of the century).

462. See OLCorT, supra note 120 , at 90,100 .

463. See id. at 91-92, 97-98.

464. See id. at 111-12, 118-26. A 1916 imperial decree conscripting Central Asians to fight against Turkey triggered a violent uprising, in part because many Central Asians felt a kinship with Turks. The uprising included organized attacks on Russian forces and major telegraph and railroad connections. See id. at 121-22. When the revolt was finally extinguished, "virtually all sectors of Kazakh society had united in protest against Russian authority." Id. at 124.

465. See id. at 121, 125.

466. See Olcott, supra note 119, at 211-12.

467. Toward the same end, Russian authorities changed the Kazakh writing system twice: first from Arabic (the traditional language of the literati in Central Asia) to Latin beginning in the 
1924 created-paradoxically, as many commentators have noted ${ }^{468}$ - the new Kazakh, Kyrgyz, Tadzhik, Turkmen, and Uzbek Soviet Socialist Republics. ${ }^{469}$ For Kazakhstan, the Soviet period was a combination of Russian exploitation and significant economic development. Moscow's policy was to use Kazakhstan "as a kind of contiguous Third World" source of raw materials and as a dumping ground for prisoners and undesirables. ${ }^{470}$ Soviet collectivization policies (between roughly 1926 and 1939) led to a shocking 1.5 million Kazakh deaths, attributable in some cases to violence but more commonly to starvation. ${ }^{471}$ At the same time, starting in the 1950s, Soviet economic policies brought to Kazakhstan agricultural modernization, numerous heavy industries, and science and research facilities such as the Soviet space exploration center in Baikonuralong with millions of Russians and Ukrainians and terrible ecological destruction. ${ }^{472}$

Since independence, ${ }^{473}$ Kazakhstan under Nazarbayev has embarked on aggressive marketization. In the last several years, the government has eagerly embraced IMF reforms, ${ }^{474}$ adopted over 130 market-friendly laws, ${ }^{475}$ expanded trade vigorously, ${ }^{476}$ privatized (after a slow start) most of

1920s, and then from Latin to Cyrillic beginning in 1940. See CENTRAL ASIA, supra note 120, at 79-82.

468. Many have observed that Soviet nationality policies, over a span of 70 years, produced "two outcomes antithetical to the officially proclaimed goals of merging nationalities and transcending ethnic distinctions." Fhilip Goldman et al., Introduction to FROM UNON TO COMMONWEALTH, supra note 121, at 1-2. First, these policies led to the emergence of nations and national identities in many communities that previously had not achieved ethnic consciousness. Second, they created in the new republics the preconditions for independent existence, including their own political elites and educated middle classes and their own administratively defined territories. See id.

469. See GLEASON, supra note 461, at 49-50; JACK F. MATLOCK, JR., AUTOPSY ON AN EMPIRE 34-36 (1995). Thus, among the Central Asians, previously "an undistinguished mass of various self-identifying tribes or city-states, ... [c]losely related nomadic families who had differed from one another primarily in the manner of their migrations suddenly received passports that identified them as 'Kazakhs' and 'Kyrgyz', and found themselves living in neighboring republics." Olcott, supra note 119, at 211-12.

470. Olcott, supra note 119, at 213. These unwanted groups included deported Chechens, Crimean Tatars, Volga Germans, and other North Caucasian peoples. See id.

471. See OLCOTT, supra note 120, at 184-85.

472. See GLEASON, supra note 461, at 52; Olcott, supra note 119, at 213. A large swath of land around Semipalatinsk, the Soviet Union's primary nuclear weapons testing site, has been rendered largely uninhabitable. See GLEASON, supra note 461, at 19. In addition, the Aral Sea has been reduced to half its former size by irrigation and unwise damming. See $i d$. Indeed, industrial pollution is ubiquitous. See id.

473. In contrast to the Baltic and most of the Slavic republics, none of the Central Asian states were eager for statehood. Kazakhstan declared independence in 1991; it was the last of the former Soviet republics to do so. See GLEASON, supra note 461, at 3.

474. See Kazakhstan on Target for Fresh IMF Funding, AGENCE FR.-PRESSE, Dec. 20, 1993, available in LEXIS, News Library, AFP File; Anthony Robinson \& Sander Thoenes, An El Dorado Rises from the Ashes, FN. TMMES, July 11, 1996, at 1.

475. See Sander Thoenes, Trust of People Key to Reform, FIN. TIMES, July 11, 1996, at 3. These lavs, among other things, streamlined the tax code, permitted repatriation of profits, liberalized prices, and established an autonomous central bank. See, e.g., Kazakhstan's Mineral 
its industrial giants, including the country's major oil and gold facilities, ${ }^{477}$ and signed dozens of multimillion dollar international deals. ${ }^{478}$ By and large, these marketization measures have been successful; most international observers today regard Kazakhstan as "the wealthiest... [and] the most politically stable" of the Central Asian republics ${ }^{479}$ and "a leading player" in the post-Soviet world. ${ }^{480}$

Notwithstanding the strikingly effective "sociocultural-and particularly linguistic-[R]ussification" of Kazakhstan during the Soviet era (even today many urban Kazakhs speak only Russian), ${ }^{481}$ there can be no doubt that anti-Russian feeling exists among Kazakhs. ${ }^{482}$ Perestroika exposed "the false accusations, purges, deportations, and [mass] deaths" inflicted on the Central Asian people during the Stalin era, provoking bitter and widespread outrage. ${ }^{433}$ Independence in Kazakhstan (as in the other post-Soviet republics) brought the enactment of exclusionary language, citizenship, and education policies, ${ }^{484}$ as well as a revival of Kazakh culture

Wealth Makes a Good Base for Middle Class Growth, MARKET EUR., Jan. 1, 1997, available in 1997 WL 9452244; Transition Indicators: Kazakhstan, QUEST ECON. DATABASE: EBRD TRANSITION REP., Nov. 1995, at 45.

476. By the first half of 1995, all export quotas had been abolished and most import and export licensing requirements loosened or eliminated. See Transition Indicators: Kazakhstan, supra note 475 , at 45 . The Nazarbayev government has also pursued new export routes, for example, by opening a railway to the Chinese port of Lyanyungan, by concluding an agreement to build a pipeline from Tengiz to the southern port of Novorossiisk, and by reaching an agreement-over the protests of the United States and Russia - to send oil to Iran for refining. See Robinson \& Thoenes, supra note 474, at 3; Rumblings from Kazakhstan, JANE'S FOR. REP., Feb. 6, 1997, available in LEXIS, News Library, CURNWS File; Sander Thoenes, Tough at Home, Tactful away, FN. TIMES, July 11, 1996, at 3. The government has also sought trade and investment relationships with Singapore and Malaysia, among others. See, e.g., Kazakhstan Enters into Investment Pact with Malaysia, NEW STRAITS TIMES, May 28, 1996, at 28; Grace Sung, Kazakhstan President Urges S'poreans to Invest in His Country, NEw STRAITS TimES, May 31, 1996, at 60.

477. Privatization began with a modest target-to reduce the state sector to $30-40 \%$ of gross domestic product-and took off slowly. See GlEASON, supra note 461, at 91 . In the last few years, however, the government has privatized most of its industrial giants, including the country's largest oil and gold facilities, mostly through sales to foreign interests. See Charles Clover, Kazakhs Steeled to Take Hard Line with Partners, FIN. TMMES, July 2, 1998, at 8; Charles Clover, Privatisation, June 17, 1998, at 2; Yuri Kushko, Kazakh Unions Say Privatisation Creates Ghosttowns, REUTERS EUR. BUS. REP., Apr. 2, 1997, available in LEXIS, News Library, REUEUB File; Sander Thoenes, Gold Mining, July 23, 1997, at 5.

478. See, e.g., Sander Thoenes, The 1996 Diary of Deals, FIN. TIMES, July 11, 1996, at 4. 475.

479. Kazakhstan's Mineral Wealth Makes a Good Base for Middle Class Growth, supra note

480. Keith Molkner, A Comparison of the Legal Regimes for Foreign Investment in Russia, Kazakhstan, and Kyrgyzstan, 11 INT'L TAX \& BUS. L. 71, 73 (1993).

481. CHINN \& KAISER, supra note 127, at 193; see Neil Melvin, Russia and the Ethno-

Politics of Kazakhstan, WORLD TODAY, Nov. 1993, at 208, 209.

482. See, e.g., CHINN \& KAISER, supra note 127 , at 194-96.

483. Gail W. Lapidus, From Democratization to Disintegration: The Impact of Perestroika on the National Question, in FrOM UNION TO COMMONwEALTH, supra note 121, at 49.

484. See, e.g., CHINN \& KAISER, supra note 127, at 190, 194, 198-201; TisHKOV, supra note 126 , at 128 . The required teaching of the "Kazakh version" of history has been a particular source of ethnic friction. See Melvin, supra note 481, at 209. 
and symbols. ${ }^{485}$ Such "Kazakhization" policies (fueled perhaps by "the alarmist rhetoric of the media in the Russian Federation" $)^{486}$ led to the departure of an estimated half million Russians in 1994. ${ }^{487}$

Nevertheless, in the last few years, even as marketization has intensified, Kazakh-Russian relations in Kazakhstan seem to have stabilized. In contrast to some of its neighbors, ${ }^{488}$ no significant episodes of interethnic violence have occurred in post-independence Kazakhstan. ${ }^{499}$ Moreover, in the last several years, Russian emigration from Kazakhstan has slowed dramatically, ${ }^{490}$ with significant numbers of Russians actually returning to Kazakhstan. ${ }^{491}$ All of this has made Kazakhstan something of an intriguing "success story" for academics and businesspeople alike. The only major glitch occurred in 1994, when President Nursultan Nazarbayev, who has ruled the country since independence, dissolved Parliament and took a sharp turn toward authoritarianism. ${ }^{492}$

485. See NEIL MELVIN, RusSIANS BEYOND RuSSLA: THE POLITICS OF NATIONAL IDENTITY 109 (1995). In September 1992, for example, the Parliament passed legislation returning many cities to their traditional names: Tselinograd City became Akmola, Gurev became Atyrau, Kirovo became Zhanalyk, and so on. See GLEASON, supra note 461, at 88.

486. TisHKOV, supra note 126 , at 128.

487. See Thoenes, Tough at Home, Tactful away, supra note 476, at 3 (quoting official statistics). But see MELVIN, supra note 485, at 118 (stating that 200,000 Russians left in 1994); TISHKOV, supra note 126, at 123 (stating that 400,000 left). According to some estimates, more than one million Russians left Kazakhstan between 1991 and 1995. See Vladimir Yegorov, The Russian Language as a Target of Persecution, CuRRENT DIG. POST-SovIET PRESS, Nov. 22, 1995 , at 22.

Because of the size of the Russian population in Kazakhstan, a major Russian exodus is unlikely. See TisHKOV, supra note 126, at 124. This is especially true in the northem oblasts, the birthplace and homeland of a high proportion of Russians. CHINN \& KAISER, supra note 127, at 190-91. The situation is different in other Central Asian republics, where Russians make up a much smaller portion of the population. According to one survey, $44 \%$ and $35 \%$ of the Russians in Tajikstan and Uzbekistan, respectively, believed in 1991 that "a massive Russian exodus from the republic was very likely in the near future." Kaiser, Ethnic Demography, supra note 122, at 254. Most Russians have in fact left civil-war-torn Tajikstan. See TISHKov, supra note 126, at 124.

488. Ethnic conflict in Tajikstan has climaxed "in a devastating civil war." TISHKov, supra note 126, at 128. In Kyrgyzstan, the ethnic riots that broke out in the Osh region in 1990 were among "the most violent in the territory of the former USSR." Id. at 136.

489. The last episode of interethnic violence in Kazakhstan dates back to December 1986, when Kazakh demonstrators in Almaty protested the replacement of Kunayev, a Kazakh who had held the position of Communist Party First Secretary in Kazakhstan for the previous 25 years, with Gennadii Kol'bin, a non-Kazakhstani Russian. The demonstrations turned into riots, which were violently suppressed by Soviet troops. The Almaty riots are often cited as the first manifestation of nationalism in Central Asia, although they "now seem minor in comparison to the events in other republics." CHINN \& KAISER, supra note 127, at 195-96; see GLEASON, supra note 461 , at 103 .

490. See Thoenes, Tough at Home, Tactful away, supra note 476 , at 3.

491. See Melvin, supra note 481, at 209. Many Russians returned to Kazakhstan "not simply because they were not welcomed back in Russia - which has certainly often been the case-but also because they found themselves living among Russians who were very different from themselves." Id.

492. See GlEASON, supra note 461, at 85-87; Matt Bivens, Kazakhstan Leader Tightens Grip on Reins of Power, L.A. TIMES, Apr. 23, 1995, at A8. 


\section{Satisfaction of Model Conditions}

Kazakhstan has a low per capita income, a low rate of labor productivity, a high rate of fertility, and a high proportion of the population engaged in agriculture. ${ }^{493}$ Thus, model condition one (economic underdevelopment) appears for now to be satisfied, although education and health levels are higher in Kazakhstan than in most Third World countries. ${ }^{494}$ Condition two is also satisfied. As even the brief historical sketch above makes clear, longstanding ethnic divisions exist between Kazakhs and Russians. ${ }^{495}$ Whether condition three (the presence of a market-dominant minority) is satisfied is more questionable. Russians in Kazakhstan were clearly economically privileged at least until independence, dominating key industrial and technical positions and occupying the country's best housing. ${ }^{496}$ Whether Russians are marketdominant, however, is a distinct and pivotal question, which will be discussed in detail below. Finally, condition four is not squarely met either. While Kazakhs are a relatively impoverished group with claims to being the true indigenous owners of Kazakhstan, ${ }^{497}$ they are not a majority in Kazakhstan. Kazakhs today constitute roughly forty-two percent of Kazakhstan's population, Russians constitute thirty-eight percent, and a

493. See Mandelbaum, supra note 452 , at 2 . Per capita income estimates vary significantly. Kazakhstan's State Statistics Committee estimated per capita income as of June 1996 at roughly $\$ 35$ a month. (The subsistence level set by the United Nations is $\$ 28$ a month.) According to other surveys, Kazakhstan's per capita income may be as high as $\$ 95$ a month, but even this estimate remains at developing country levels. See Kazakhstan's Mineral Wealth Makes a Good Base for Middle Class Growth, supra note 475.

494. See ShafiquI Islam, Capitalism on the Silk Route?, in CENTRAL ASIA AND THE WORLD, supra note 452 , at $147,153,157$.

495. Notwithstanding extensive interethnic contacts and linguistic Russification during the Soviet era, throughout Central Asia "the Russians and the titular population kept a cultural distance from one another. In effect, they were separate communities.... Mixed marriages between Russians and people of the local nationalities were and remain rare." TisHKOV, supra note 126, at 126. Rates of interethnic marriage, however, have "increased with rising urbanization and education rates." CHINN \& KAISER, supra note 127 , at 84.

496. See Graham E. Fuller, Russia and Central Asia: Federation or Fault Line?, in CENTRAL ASLA AND THE WORLD, supra note 452, at 94, 109-10; Kaiser, Nationalizing the Work Force, supra note 123, at 103 tbl.9 (showing underrepresentation of Kazakhs in industry, transport and communications, construction, trade, services, and science). Russians are concentrated in the most industrially developed parts of Kazakhstan, namely the capital city (Almaty) and the northeastern oblasts. See TisHKOV, supra note 126, at 121; Fuller, supra, at 110.

497. Slogans such as "Drive the Russians out of Kazakhstan" and "Kazakhstan for Kazakhs" have been around since early this century. OLCOTT, supra note 120, at 206. Such sentiments, however, appear to be relatively rare today. See infra note 513 and accompanying text. The suffix "stan" in Kazakhstan is a Persian word meaning "land of." See Richard Boudreaux, Central Asia: The Long Road to Democracy, L.A. TIMES, Dec. 25, 1996, at A1. At the same time, many Russians in Kazakhstan are descended from families who arrived in the region before the Revolution and who think of Kazakhstan, "where they-and perhaps their parents and even grandparents-were born, and many of their relatives are buried, as their 'little homeland." TISHKOV, supra note 126, at 126. 
variety of much smaller groups form the balance. ${ }^{498}$ This distinctive ethnic demography has important policy implications, as we shall see below.

\section{Analysis}

The model provides a useful framework for understanding Kazakhstan's achievement of combining significant marketizing success with ethnic stability. This relative ethnic amicability may rest in part on factors specific to Kazakh history and culture, such as the absence of a strong current of Islamic fundamentalism and Russification of urban Kazakhs. ${ }^{499}$ Without denying the salience of such factors, the model suggests three other possible explanations of the current situation in Kazakhstan.

\section{a. Retreat from Democracy}

First, Kazakhstan has already suffered a major retreat from democracy. To be sure, in form, Kazakhstan has a tripartite government with independent executive, legislative, and judicial branches. ${ }^{500}$ Additionally, opposition groups-including nationalist, socialist, and communist parties-exist and operate in public. ${ }^{501}$ Nonetheless, the substance of the Kazakhstan government for now is Nazarbayev, who was elected president in an uncontested election, ${ }^{502}$ who presides over a largely impotent Parliament, ${ }^{503}$ and who can make laws through unilateral decrees. ${ }^{504}$ It is therefore arguable that Kazakhstan already occupies a variant of model outcome three: A retreat from democracy may have helped Kazakhstan maintain both the market and its Russian minority.

498. See Kazakhstan: 1996, QUEST ECON. DATABASE: BUS. INTELLIGENCE REP. WORLD OF INFORMATION, Oct. 1996, at 1 [hereinafter 1996 Kazakhstan Country Profile]. The demographics of Kazakhstan have shifted dramatically over this century. In 1926, Kazakhs constituted approximately $57 \%$ of the total population; by 1959 , this figure had dropped to just $30 \%$. See Harris, supra note 124, at 5 tbl.1. According to the 1989 Soviet census, Kazakhs and Russians represented $39.7 \%$ and $37.8 \%$, respectively, of Kazakhstan's total population. See CHINN \& KAISER, supra note 127, at 189. After independence, many Russians left, resulting in the rough proportions of Kazakhs and Russians noted in the text.

499. See Olcott, supra note 119, at 218; Melvin, supra note 481, at 209. Nazarbayev has consistently "distanced himself from a religious identification. Alone among the Central Asian republics, Kazakhstan recognizes no Muslim holidays, and does not mention Islam in its constitution." Olcott, supra note 119, at 219.

500. See KONSTITUTSIIA [Constitution] art. $3, \S 4$ (Kaz.).

501. See GLEASON, supra note 461 , at $86,88-89$.

502. See Elliot, supra note 453 , at $1246-47$.

503. The country's legislature, twice dissolved by Nazarbayev, now functions as little more than an advisory body. See GLEASON, supra note 461, at 86-87.

504. Under the so-called Nazarbayev Constitution, passed in 1995 with a 90\% majority, presidential decrees essentially have the force of law. See id. at 87. 
On this view, the argument would be that Nazarbayev has used his autocratic power to check majoritarian anti-Russian sentiment. There is some evidence of this. A career Communist Party member initially put into power by Moscow, Nazarbayev has always been relatively solicitous of his country's large Russian constituency. ${ }^{505}$ In recent years, Nazarbayev has repeatedly urged interethnic accord, both because of the importance of Russian skills "to the economy and because of the necessity to maintain good relations with Russia itself." ${ }^{506}$ Russian language newspapers, including the flagship Kazakstanskaya Pravda, operate freely, often voicing dissent. ${ }^{507}$ More crucially, under Nazarbayev's direction, Russian was made an official language alongside Kazakh in 1997. In addition, Russian language schools in Kazakhstan are now encouraged to stay open. ${ }^{508}$ Finally, while significant "Kazakhization" of the country's political apparatus has clearly taken place-Kazakhs now dominate the leading central ministries, the judiciary, and most spheres of public administration ${ }^{509}$ - Nazarbayev has also been careful to permit Russian Kazakhs to occupy key, visible official positions. ${ }^{510}$ Indeed, many Russians

505. See Elliot, supra note 453 , at 1245-47; Olcott, supra note 119 , at 209,225 . But see Yegorov, supra note 487 (suggesting that Nazarbayev has deliberately aroused anti-Russian sentiments). Described by one commentator as "an Asian who thinks like a European," Nazarbayev was the only ethnic minority to be seriously considered as successor to Mikhail Gorbachev. GLEASON, supra note 461, at 83. Early popularity polls showed that "ethnic Russians approved of Nazarbayev's politics even more than did ethnic Kazaks." Id.

506. Elliot, supra note 453, at 1245; see Chris Bird, Poverty Overshadows Kazakh Independence, REUTERS WORLD SERV., Dec. 16, 1996, available in LEXIS, News Library, REUWLD File.

507. See GlEASON, supra note 461, at 89-90, 132; Sander Thoenes, Kazakh Dissent Stilled by Silence, FIN. TIMES, Sept. 10, 1996, at 6 . Shortly after independence, Nazarbayev (who according to Neil Melvin was "conducting extensive opinion-polling among Europeans") sought to integrate influential Russians into "a pan-ethnic political organization, the Union of People's Unity of Kazakhstan." Melvin, supra note 481, at 209.

508. The study of Kazakh, however, is still mandatory. See CHINN \& KAISER, supra note 127 , at 194.

509. See KULCHIK ET AL., supra note 125, at 36-37; MELVIN, supra note 485, at 109-10. According to Chinn and Kaiser, the March 1994 parliamentary elections provide a stark example of political Kazakhization:

Of the 177 parliamentary seats, 42 were filled by the president rather than by election.

Over 700 candidates competed for the remaining 135 seats, giving the appearance of a democratic election. However, Kazakh electoral commissions struck 200 potential candidates from local ballots. These candidates tended to represent Russian nationalist positions. In addition, Cossack organizations were not allowed to field candidates.... As a result of such preelection maneuvering, only 128 Russian candidates appeared on the ballots, compared to 566 Kazakhs, even though voting-age Russians outnumbered Kazakhs.

CHINN \& KAISER, supra note 127, at 200 (footnote omitted). At the same time, from the perspective of Kazakhs in the west, north, and east (the Small and Middle Hordes), "Kazakhization" is in fact often "a cover for the advancement of the interests of the Great Horde or southerners. Many of the Kazakhs appointed to high and middle-level [political] positions are from the south." MELVIN, supra note 485, at 110; see infra text accompanying notes 526-527 \& 535-537.

510. See MELVIN, supra note 485 , at $116,120$. 
purportedly view Nazarbayev "as the only man who can slow down the development of Kazakh domination of the country." 511

While the model provides no grounds for assuming that an authoritarian leader would choose to pursue ethnic accommodationism (rather than, say, eliminationism), the model does predict that leaders who seek both to marketize and to accommodate an economically dominant minority in the face of a resentful, impoverished majority will find it easier to do so under nondemocratic conditions. The problem, however, is that the Kazakhs are not in fact a resentful, impoverished majority. In fact, taken together, the Russian, Ukranian, and German Kazakhs - traditional political allies, often misleadingly referred to as the "Russian-speaking" population-are very nearly equivalent in number (approximately forty-seven percent of the population) to the Kazakhs. ${ }^{512}$

Moreover, there is a danger of mistaking cause for effect in attributing Kazakhstan's current ethnic stability to Nazarbayev, however shrewd or powerful he may be. Many autocrats have unsuccessfully tried to "impose" ethnic harmony (indeed, one of the model's corollaries is that leaders can much more easily foment than control ethnonationalist movements). If Nazarbayev were forcing ethnic accommodation upon a recalcitrant Kazakh populace, one would expect to see many more eruptions of suppressed antiRussian resentment. But again, no significant outbreaks of anti-Russian violence have occurred in postindependence Kazakhstan. Recent surveys suggest that most Kazakhs wish to coexist peacefully with Russians and, to a significant extent, with Russian culture. ${ }^{513}$

\section{b. Russians and Market Dominance}

A second possible explanation is that the Russian Kazakhs are not a market-dominant minority. If Russians are not market-dominant in Kazakhstan, then marketization would not be expected under the model to fuel ethnonationalist resentment and backlash among Kazakhs. This possibility, together with Nazarbayev's accommodationist efforts, could account in substantial part for Kazakhstan's success in combining marketization with relative ethnic stability.

511. Elliot, supra note 453 , at 1247.

512. See 1996 Kazakhstan Country Profile, supra note 498, at 1. Most Kazakhs also speak Russian. See CHINN \& KAISER, supra note 127, at 194.

513. According to one sociological survey taken in Kazakhstan in December 1994, both Kazakhs and Russians "want to learn the language and culture of the other [group], and to live in a cooperative, peaceful way." TISHKOV, supra note 126 , at 127 . The great majority (80.6\%) of surveyed Kazakhs endorsed the compulsory study of Russian in school. See id. Somewhat at odds with the survey, however, Chinn and Kaiser observe that "Russians have for the most part resisted learning Kazakh" on the grounds that "the utility of Kazakh is limited outside Kazkahstan" or even in the Russian-dominated northern oblasts. CHINN \& KAISER, supra note 127, at 194. 
Throughout the imperial period, Russians in Kazakhstan were obviously economically dominant-and possibly even market-dominant, to the extent it can be said that market conditions existed in tsarist-era Kazakhstan. ${ }^{514}$ Russians remained an economically hegemonic group during the Soviet era. ${ }^{515}$ Kazakhs are still disproportionately rural and lag behind their Russian counterparts in education, technical skills, and per capita income. ${ }^{516}$ For this reason, some believe that Russians would outperform Kazakhs under free-market conditions. ${ }^{517}$ However, the extent to which Kazakhstan's current ethnoeconomic disparities simply reflect discriminatory Soviet-era biases, which the market should now correct, is an open and pivotal question.

Kazakhs today are no longer nomadic, ${ }^{518}$ their literacy and secondary education levels are impressively high (comparable to those in the East Asian Tigers) ${ }^{519}$ and there is no compelling evidence to suggest that they are "intrinsically" or culturally less "entrepreneurial" than their Russian counterparts. ${ }^{520}$ Indeed, some evidence suggests that market policies are not reinforcing the historical economic dominance of Russians over Kazakhs in Kazakhstan but rather undercutting that dominance. For example, many Russian Kazakhs occupied positions in the state-supported, "outdated factories that are among the hardest hit by [market] reforms." ${ }^{521}$ Similarly, the recent shift away from the heavy industrial and military sectors to "commercial, brokering, and financial activity" appears to have favored Kazakhs systematically over Russians. ${ }^{522}$

Nevertheless, it is much too early to know whether marketization in Kazakhstan will favor Kazakhs or Russians (or neither). Many of the economic problems experienced by the Russian Kazakhs in the northern

514. In the late-19th and early-20th centuries, the sudden opening up of commerce and trade in the steppe benefited Russian farmers and livestock breeders almost exclusively. The vast majority of Kazakhs, whose farming remained extremely primitive, could not-or would nottake advantage of the rapidly growing markets in the north. See OLCOTT, supra note 120 , at 85 , 98.

515. See Kaiser, Nationalizing the Work Force, supra note 123, at 96 . Starting in the 1970 s, however, most of the Soviet republics embarked on "indigenization" movements. As a result, even in the late Soviet era, Kazakhs came to dominate white collar management positions as well as high-status professions such as teaching, literature, arts, and science. See id. at 91, 97-99, 100 tbl.6.

516. See KULCHIK ET AL., supra note 125, at 38. Russians are still overrepresented in Kazakhstan's industrial, transportation, communications, engineering, construction, science, textiles, and electronics sectors. See Kaiser, Nationalizing the Work Force, supra note 123, at 9495; Olcott, supra note 119, at 213.

517. See KULCHIK ET AL., supra note 125, at 21.

518. See OLCoTT, supra note 120 , at 253.

519. See Islam, supra note 494, at 153, 157.

520. In fact, some have argued that Russians-both in and outside of Russia-are culturally not entrepreneurial. See, e.g., ALFRED J. RIEBER, MERCHANTS AND ENTREPRENEURS IN IMPERIAL RUSSIA 21-24, 29-30 (1982).

521. See Thoenes, Tough at Home, Tactful away, supra note 476 , at 3.

522. TISHKOV, supra note 126, at 122. 
oblasts may reflect temporary economic dislocations resulting from the collapse of the former Soviet Union. ${ }^{523}$ Moreover, as the next Section elaborates, some recent Kazakh economic advances may not reflect market forces at all but rather an ethnocratic bias in the country's recent marketization initiatives.

\section{c. Anti-Russian, Antimarket Backlash?}

The possibility of a systematically pro-Kazakh bias in Nazarbayev's marketization program suggests a third explanation of why marketization in Kazakhstan has not led to anti-Russian animus. According to this view, "[c]ontrary to all declarations about the republic's advance towards a freemarket economy," 524 the Nazarbayev government is in fact circumventing market forces in order to protect "the interests of the ethnocratic state and nascent national Kazakh elite." 525 Specifically, critics argue that the government deliberately rigged Zhekeshelendiru - the voucher privatization program through which many of the country's state-owned enterprises were transformed into corporations with shares and shareholders ${ }^{26}$ - to favor Kazakhs in general and the elite clan of the Great Horde (from which Nazarbayev hails) in particular. ${ }^{527}$ Similarly, privatization of land, which almost certainly would have "favor[ed] the Slavs and Uzbeks both, because they are able to do small-plot farming, unlike Kazakhs," ${ }^{528}$ allegedly was conducted in a way that left title of all agricultural land in state hands, leading some to label the process "ethnoprivatization." 529 In addition, the government has been accused of "blocking contacts between foreign

523. See Kaiser, Nationalizing the Work Force, supra note 123, at 105. Russians in Kazakhstan tended to be concentrated in the "all-union" industries in northern Kazakhstan that formerly

produced goods for the whole of the Soviet Union. Following independence, the Russian Federation quickly closed its southern border, thereby denying these enterprises access to their main markets. At the same time, the Russian [government] ... slashed purchases of military equipment from Kazakhstan. ... The combined effect of these policies was to create severe economic difficulties among the very populations Russia is so keen to "defend."

Melvin, supra note 481, at 209.

524. KULCHIK ET AL., supra note 125 , at 24.

525. Id. at 26.

526. See GLEASON, supra note 461, at 92-94.

527. See Melvin, supra note 481, at 209-10. Kazakhstan's privatization program drew upon the so-called Czech model, under which Privatization Investment Coupons (PICs), or vouchers, were initially distributed to the general population. The PICs were not freely tradable and could only be invested in government Investment Privatization Funds. These Funds in turn acquired shares in newly formed joint stock companies. See GLEASON, supra note 461, at 93. According to critics, the government has blatantly favored funds representing certain Kazakh clans from southern Kazakhstan. See KULCHIK ET AL., supra note 125, at 24.

528. Olcott, supra note 119 , at 225; cf. Belcuore, supra note 79 , at 466 (noting that private ownership of land long was anathema to the nomadic Kazakhs).

529. KULCHIK ET AL., supra note 125 , at 23 . 
investors and non-Kazakh market operators, which, they fear, might stimulate the development of a Russian-speaking bourgeoisie." 530 These claims, if true, would support a theory that Kazakhstan currently falls into model outcome one. ${ }^{531}$

\section{Directions}

For purposes of the model, the two most salient facts about Kazakhstan are the country's unusual demographic balance and the substantial possibility that the Russian minority, although historically economically dominant, will not prove to be market-dominant. Given Kazakhstan's particular demographics, it cannot be assumed that democracy would lead to an ethnocratic state or even to the election of predominantly ethnic Kazakh leaders. As a result, while the model suggests that democratization likely will lead to some explicit ethnopoliticking in Kazakhstan (as is often the case in divided societies) ${ }^{532}$ the model does not predict that democracy in Kazakhstan will necessarily present a serious obstacle to marketization. Even assuming that the Russian Kazakhs are market-dominant, democratization is unlikely to produce irresistible majoritarian, antimarket pressures-again for the simple reason that Kazakhs are not a majority in Kazakhstan. And, as already discussed, it is not clear that the Russians are in fact market-dominant.

Accordingly, the model suggests that Kazakhstan, to a greater degree than most developing countries, may be a receptive candidate for the stable, simultaneous, ethnically neutral pursuit of markets and democracy. Nazarbayev's current autocracy-which, despite his assertion that "democracy is knocking on the door," 533 shows no sign of abating-is causing increasing concern, domestically and internationally. ${ }^{534}$ Moreover, Nazarbayev's blatant pursuit of not just ethnomarketization (favoring Kazakhs over the Russian-speaking population), but also clannism and nepotism, is drawing intensifying criticism from Kazakhs and non-Kazakhs alike. ${ }^{535}$ As one observer has remarked: "[Nazarbayev's] rule has been accompanied by clan appointments and favoritism that have pitted Kazakh

530. Id. at 26. "Those foreign investors who established direct contact with the [Kazakh] ruling circles, such as Chevron and Samsung, have achieved the most spectacular results." Id. at 25.

531. More precisely, on this theory, Russians are market-dominant, and the absence of a significant anti-Russian backlash against Nazarbayev's marketization policies would be owing to the fact that these policies already incorporate an effective anti-Russian component.

532. See sources cited supra note 211.

533. Douglas Busvine, Kazakh Polls Keep Nazarbayev in Control, REUTERS WORLD SERV., Dec. 10, 1995, available in LEXIS, News Library, REUWLD File.

534. Sce id.; Thoenes, supra note 507, at 6.

535. See Melvin, supra note 481 , at 210. 
against Kazakh. Thus, while for many in the European community the policy of 'Kazakhization' represents an ethnic threat, in the Kazakh community it is seen as the growing dominance of the Great Horde." 536 Similarly, in a local critic's view, "[n]ot talent but connections determine everything. It's the ability to give the right bribes, not the ability to run a company. There are no equal opportunities here. If I were married to the daughter of Nazarbayev I would be one of the country's wealthiest businessmen." 537

Some, perhaps even most, of Nazarbayev's pro-Kazakh market interventions to date may be justifiable on grounds of corrective justice. Moreover, these interventions, together with other Kazakhization policies, may have played an important role in defusing anti-Russian animus during the emotionally charged transition period following independence. ${ }^{538}$ In light of the available evidence, however, persistence by the Nazarbayev government in systematically favoring Kazakhs, particularly those who are well positioned either by family or clan, may simply constitute illegitimate ethnocracy, if not outright corruption. On balance, in the absence of compelling evidence that Russians are market-dominant, a strong argument can be made that marketization in Kazakhstan should be given a chance to proceed in an ethnically neutral manner. Should Russian market dominance begin to emerge after a period of time, it might then be appropriate to consider which, if any, measures should be adopted to address that contingency.

There is an additional reason for Nazarbayev to avoid favoring ethnic Kazakhs. Russians in Kazakhstan are geographically concentrated in the northern part of the republic, near the border of Russia. ${ }^{539}$ Russians actually constitute a majority of the population in three of Kazakhstan's northern oblasts and a plurality in four others. ${ }^{540}$ Empirical evidence suggests that when ethnic groups are geographically segregated, there is a much greater likelihood of secessionist initiatives and the violence that often accompanies them. ${ }^{51}$ Indeed, most political analysts agree that special dangers attend Kazakhstan's northern oblasts, "where Russians have lived for generations, remain in the majority, and have developed a strong sense of homeland." 542

536. $I d$.

537. Thoenes, supra note 507, at 6 (quoting Pyotr Svoik, a former minister turned opposition leader in Kazakhstan).

538. See, e.g., Boudreaux, supra note 497, at A1 (quoting Neil J. Melvin); Busvine, supra note 533.

539. See CHINN \& KAISER, supra note 127 , at 185.

540. See id.

541. See Fearon \& Laitin, supra note 165 , at $3,12-13,33$.

542. CHINN \& KAISER, supra note 127 , at 190 . On the other hand, it may be propitious for Kazakhstan that within the northem oblasts Russians and Kazakhs generally live interspersed and 
In an attempt to forestall secessionism, and in what most Russians resent as a deliberate effort to "Kazakhize" the population in the north, the Nazarbayev government has encouraged Kazakhs returning from other former Soviet republics and from foreign states to settle in northern Kazakhstan. ${ }^{543}$ These efforts at "demographic indigenization" have generally been successful: Notwithstanding significant Russian migration from the Kazakh-dominated southern oblasts to the northern oblasts, Kazakh population growth in the north has outpaced that of the Russians. ${ }^{544}$

Nevertheless, the transition period over the next several years could be "potentially explosive." 545 As more and more Kazakhs move to the north, the Russians in the region "will be tempted to opt for secession while they still hold the majority rather than to wait for a time in which they will no longer be able to prevail in an independence referendum." ${ }^{546}$ Hence, if Nazarbayev goes too far in "ethnocratizing" Kazakhstan's economy and politics, he risks triggering an ethnonationalist backlash among the Russian populace, with potentially catastrophic consequences, including armed retaliation, intervention by Russia, or the forcible secession of the Russiandominated northern oblasts, which many Russian nationalists view as "an integral part of Russia." ${ }^{547}$

Finally, if and when democratization proceeds in Kazakhstan, it will be essential to structure the electoral regime in a way that creates incentives for interethnic political alliances. Indeed, the prospects for "constitutional engineering" may be especially fruitful in a country with Kazakhstan's ethnodemographic characteristics. ${ }^{548}$ Given the closely balanced numbers of Kazakhs and Russians in the country, ethnically conscious tailoring of the democratic process might prove particularly effective. For example, electoral systems that require majority support (as opposed to proportional representation) might be effective in discouraging the formation of divisive, ethnocentric political parties in Kazakhstan. ${ }^{549}$

in fairly balanced numbers. According to one study, societies with high levels of ethnic dispersion and intermixing in cities are associated with lower levels of ethnic violence. See Fearon \& Laitin, supra note 165 , at $20-21$.

543. Most of these Kazakhs have returned from Mongolia, where many Kazakhs fled in the 1930 s to avoid Stalinist persecution. See CHINN \& KAISER, supra note 127, at 191 (citing COMMISSION ON SEC. \& COOPERATION IN EUR. (CSCE), HUMAN RIGHTS AND DEMOCRATIZATION IN THE NEWLY INDEPENDENT STATES OF THE FORMER SOVIET UNION 19596 (1993)). Repatriation has been fostered by financial subsidies and a 1991 citizenship law that grants automatic citizenship (and permits dual citizenship, unlike for Russians) to Kazakhs from outside Kazakhstan. See id.

544. See id.

545. Id.

546. Id.

547. Kaiser, Ethnic Demography, supra note 123, at 254.

548. HOROWITZ, supra note 322, at 163.

549. See generally id. at 163-203. 


\section{Vietnam}

\section{Background}

Vietnam's recorded history begins in 208 B.C., when a renegade Chinese general conquered Au Lac, a domain in the northern mountains of Vietnam populated by the Viet people, and declared himself emperor of Nam Viet. ${ }^{550}$ A century later, the powerful Han dynasty incorporated Nam Viet into the Chinese empire, and for the next thousand years, Vietnam was ruled as a province of China. ${ }^{551}$ During this period of Chinese colonization, and for many centuries afterwards, waves of Chinese immigrantsbureaucrats, scholars, and merchants, as well as soldiers, fugitives, and prisoners of war-settled in Vietnam. ${ }^{552}$ By the end of the seventeenth century, a distinct Chinese community (known in Vietnam as the Hoa) had formed within Vietnamese society:

Small Chinatowns sprouted in or close to almost every big city and major trading centre.... [T] he increasing numbers [of Chinese] allowed them to congregate according to dialect groups or kinship or even the causes which led to their leaving China. Their growing economic sophistication also meant the creation of institutions to regulate business activities . . . ${ }^{53}$

Resentment of growing Chinese success and affluence in Vietnam, coupled with repeated attempts by China to conquer Vietnam, sparked recurrent anti-Hoa reprisals. Most notably, the bloody Tay Son uprising, which began in the 1760 s and "took its roots from widespread peasant discontent," specifically targeted the Chinese, "a distinctive urban élite." 554 Tay Son rebels took over the country in 1788. It was during the brief Tay Son reign that the Chinese were massacred in Cholon. ${ }^{55}$

With the establishment of the Nguyen dynasty in 1802, Chinese business activities in Vietnam again flourished. ${ }^{556}$ The Nguyen emperors, who embraced Confucianism and modeled their imperial court after China's court, had a symbiotic relationship with the country's Chinese:

550. See STANLEy KARNOW, Vietnam: A History 111 (rev. ed. 1991).

551. See GOLAY ET AL., supra note 95, at 392; KAMM, supra note 144, at 73; KARNOW, supra note 550, at 111 .

552. See KHANH, supra note 104, at 14-16.

553. Id. at 16.

554. Id. at 18-19. The Chinese sided with the emperor against the Tay Son rebels. See AMER, supra note 296 , at 9 n.20.

555. See KHANH, supra note 104, at 19.

556. See id. at 19-20. 
The Nguyen rulers used Chinese merchants in the collection of taxes, encouraged them to set up shipyards to build boats and ships, allowed them to buy houses, acquire land, and form their own social and economic organizations. Historical records show that in some economic sectors, the Chinese were even more favoured than the Vietnamese.... In the first half of the nineteenth century, the Nguyen court exempted new Chinese immigrants from all taxes [for three years]. Such preferential treatment for the Chinese community helped them to expand their economic power. ${ }^{557}$

The increasing wealth of the Chinese community served the interests of the ruling officials, who received financial kickbacks from lucrative Chinese businesses. ${ }^{558}$ By the time the French arrived in the mid-eighteenth century, the Chinese were firmly embedded in Vietnam's economy, particularly in the commercial, trade, and mining sectors. ${ }^{59}$ Vietnam's gold industry, in particular, was monopolized by Chinese merchants. ${ }^{50}$

Although the French only grudgingly tolerated the Chinese, controlling their immigration and prohibiting their involvement in the natural resources sector, the Chinese in Vietnam thrived under colonial free-market policies. ${ }^{561}$ Indeed, favorable economic conditions brought a rapid influx of Chinese immigrants (almost all of whom settled in the south), which continued until the middle of the twentieth century ${ }^{562}$ By the 1930 s, "the interstices between the large-scale manufacturing, plantation, commercial, and financial enterprises of the French were filled by the smaller enterprises of the Chinese." ${ }^{563}$ At the same time, the French policy of treating the Chinese as an outsider community "enhanced the distinctiveness of this minority and sustained latent Vietnamese hostility." 564 The magnitude of the Chinese minority's economic power was astounding: Constituting just one percent of Vietnam's population, the Chinese controlled an estimated ninety percent of non-European private capital in the mid-1950s and dominated Vietnam's retail trade, its financial, manufacturing, and

557. Id.

558. See id. at 20.

559. See GOLAY ET AL., supra note 95, at 395; KHANH, supra note 104, at 20.

560. See KHANH, supra note 104 , at 18.

561. See GolAY ET AL., supra note 95, at 396; KHANH, supra note 104, at 57. The French took advantage of Chinese market expertise by entering into a number of cooperative commercial ventures, including joint rice exporting efforts to Hong Kong, Shanghai, and Singapore. See KHANH, supra note 104, at 57.

562. According to one estimate, 1.2 million Chinese arrived in Vietnam between 1923 and 1951. See KHANH, supra note 104, at 22.

563. GOLAY ET AL., supra note 95 , at 396.

564. Id. This was true even though the French banned many expressions of Chinese culture in Vietnam-for example, by abolishing the Confucian examination system and the official use of Chinese characters-as part of an effort to break Vietnam's links with China and thus "to isolate Vietnam from its heritage and to neutralize the traditional elite." ANDERSON, supra note 150, at $126 \mathrm{n} .23$ (citations omitted). 
transportation sectors, and all aspects of the country's rice economy. ${ }^{565}$ Although there were also numerous wealthy Vietnamese in the commercial class, Chinese economic dominance produced (as it did throughout Southeast Asia) a bitter outcry against "the Chinese stranglehold on Indochina," "the Chinese cyst," and "the Chinese excrescence," triggered recurrent state retaliation, whether in the form of coercive assimilation policies ${ }^{567}$ or anti-Chinese commercial restrictions. ${ }^{568}$

The French granted Vietnam independence in 1954. With the division of the country into two halves, the south became the Republic of Vietnam (ROV), and the north became the Democratic Republic of Vietnam. ${ }^{569}$ Roughly eighty-five percent of Vietnam's Chinese population lived in the ROV ${ }^{570}$ and despite an early, abortive "Vietnamization" drive, ${ }^{571}$ Chinese economic dominance prevailed during the twenty years of the Saigon regime-that is, from 1955 to $1975 .^{572}$ Particularly during the Vietnam War (which the Vietnamese call the American War), the wealth of the "compradore bourgeoisie" ${ }^{573}$ in the ROV rapidly intensified:

565. See GolAY ET AL., supra note 95, at 395; KHANH, supra note 104, at 20-21, 41, 47; Tsung-to Way, Overseas Chinese in Vietnam, FAR E. ECON. REV., Jan. 2, 1958, at 20, $20-22$.

566. PURCELL, supra note 266, at 190 (citation omitted).

567. As early as the 15th century, the Vietnamese government required Chinese residents to "conform with Vietnamese customs and traditions, even to the extent of dressing the Vietnamese way." KHANH, supra note 104, at 17. Interestingly, when China's Han dynasty ruled Vietnam centuries earlier, the Chinese similarly-and unsuccessfully-tried to assimilate the Vietnamese, for example, by "establish[ing] schools to spread the Chinese language, which became the idiom of learned Vietnamese...." KARNOW, supra note 550, at 111.

568. Between 1955 and 1957, the Republic of Vietnam's (ROV) "Vietnamization" drive effectively forced the Chinese in Vietnam to choose between their Chinese identity and their means of livelihood: Under a series of presidential decrees, members of Vietnam's Chinese community who did not take on Vietnamese citizenship were prohibited from operating rice mills, acting as commercial middlemen, transporting goods and passengers, and engaging in areas of trade traditionally dominated by the Chinese. See AMER, supra note 296, at 19-20; KHANH, supra note 104, at 53. Another law required the Vietnamese language be used in all Chinese high schools and mandated that all principals appointed to Chinese schools be Vietnamese. AMER, supra note 296, at 20. The ROV's attempts to curtail the economic power of the Hoa failed. By closing down business operations "and by withdrawing large amounts of money from the banks, the Chinese virtually brought the [ROV's] economy to a standstill by the summer of 1957." Id. at 21 (citation omitted). Shorty afterwards, ROV authorities effectively retracted the anti-Chinese decrees. See id. at 21-22.

569. The United States replaced France as the primary supporter of anti-Communist South Vietnam, ruled by Ngo Dinh Diem. See KAMM, supra note 144, at xiv; KHANH, supra note 104, at 22-23.

570. See KHANH, supra note 104, at 23. In northern Vietnam, the Chinese made up a very small portion of the population and, in stark contrast to the Chinese in the south, were predominantly rural- "mainly fishermen, foresters and craftsmen." AMER, supra note 296, at 12, 18.

571. See supra note 568.

572. See AMER, supra note 296, at 23.

573. "Compradore" bourgeoisie, from the Portugese word for "buyer," was the official Communist term for local agents who had made money by acting on behalf of foreign capitalists. See KHANH, supra note 104, at 79. In the Vietnamese context, the southern compradore bourgeoisie included both Vietnamese and Chinese businessmen, who were decried as "reactionary in politics" and "[in collusion] with imperialism and the Saigon regime." Id. 
This was a time when opportunities for business came with the U.S. need for a trade and service network to supply its troops fighting in Vietnam. The post-1964 years also saw an ROV government inclined to deregulate the economy and promote liberal market practices. Local Chinese businessmen were quick to seize these opportunities and expanded operations not just in their traditional strongholds of trade and services, but also in finance and light industries.... The political underside of such economic practice was the inevitable corruption of the power élite. In order to operate... [the disadvantaged local Chinese] had to cultivate the politicians and military leaders of the ROV. At the simplest level it was wining and dining them. But a more serious form involved the use of huge monetary bribes or offers of shares in businesses. ${ }^{574}$

Following the country's reunification in 1976, the revolutionary Vietnamese government singled out the entrepreneurial Chinese of the south as "bourgeois" and "an important part of world capitalism," 575 arresting and brutalizing thousands ${ }^{576}$ and confiscating their property, along with that of their Vietnamese counterparts. ${ }^{577}$ In March 1978, all private trade was banned in Vietnam. A few months later, the government introduced a new currency and rendered existing money holdings worthless, thus completing its campaign to transform Vietnam into a socialist society. ${ }^{578}$ Vietnamese authorities claim that this "campaign was not directed against any particular ethnic group." 579 Nonetheless, a disproportionate number of Vietnamese Chinese were affected. Many former businessmen and traders were left "without any means of sustaining themselves." 580 Others faced forcible relocation to "new economic zones." ${ }^{581}$ As a result, many thousands of Chinese from the former ROV fled the country. ${ }^{582}$

574. Id. at 80. During the Saigon regime, "[s]ome of the Chinese capitalists came to be called Kings due to their dominant position in trade in different products. ... [Hence] the Rice King and the Petroleum King, only to mention a few." AMER, supra note 296, at 23 (footnote omitted).

575. Henry Kamm, Vietnam Describes Economic Setbacks, N.Y. TMES, Nov. 19, 1980, at A9 (citation omitted).

576. See KHANH, supra note 104, at 81 (footnote omitted).

577. See AMER, supra note 296, at 35-36, 53-54; KHANH, supra note 104, at 81; see also James N. Wallace, A Ray of Hope, U.S. NEWs \& WORLD REP., Aug. 6, 1979, at 50 ("Employing the techniques Hitler used to inflame hatred against the Jews, Hanoi is blaming day-to-day problems in Vietnam on resented Chinese control of commerce and the Mekong Delta rice trade.").

578. See AMER, supra note 296, at 55.

579. Id.

580. Id. at 56.

581. Id.

582. See id. After April 1978, the number of people leaving southern Vietnam by boat to other Southeast Asian countries rose to 5000 a month. See id. Around the same time, more than 160,000 Chinese left the former North Vietnam for China. See id. at 46-47; supra note 296. In 
In $1986,{ }^{583}$ after years of economic disaster and famine, and in the face of triple-digit inflation, unmanageable debt, and declining aid from Sovietbloc countries, the Vietnamese government launched a program of economic liberalization, known as doi moi ("renovation"), designed to move Vietnam away from centralized planning toward a market-based economy ${ }^{584}$ The implementation of doi moi has been described as follows:

[S]ince 1988, Vietnam has given free priority to maintaining macro-stability while concentrating its limited administrative resources on strengthening the institutional base of its emerging market economy in order to promote micro-stability. There has been no rush to privatize SOEs [state-owned enterprises] ... as in Eastern Europe. Instead, the promotion of micro-efficiency has focused on price liberalisation, on creating space for the growth of the private sector and, finally, on imposing market discipline on SOEs both by removing the soft budget constraint and by exposure to international competition. ${ }^{55}$

The effects of doi moi, in particular the inflow of foreign investment, have been more pronounced in southern Vietnam than in northern Vietnam. As of 1995, the Mekong Delta and Ho Chi Minh City had almost 30,000 private-owned enterprises, in contrast to roughly 3400 in Hanoi and Haiphong. ${ }^{586}$ Following familiar development patterns, doi moi has also

1979, a high-ranking Vietnamese official who defected to Beijing described the egregious mistreatment of the Chinese in Vietnam:

They have been expelled from places where they have lived for generations.... They have been dispossessed virtually of all their possessions, their land, their houses and other belongings.... They have been driven into what have been called new economic zones.... They gradually die for a number of reasons, either from disease, suffering from the hard life and so on.

Vietnamese Defector Assails Hanoi's Policy on China, WASH. POST, Aug. 10, 1979, at A23 (quoting Hoang Van Hoan, former Vice Chairman of the Standing Committee of the Vietnamese National Assembly) (quotation marks omitted).

583. Although Vietnam's shift to economic liberalization is widely dated to the landmark Sixth Conference, Eighth Plenum of the Communist Party of Vietnam, which occurred between June 10 and June 17 of 1986, a progressive loosening of Vietnam's centrally planned economy has been taking place since 1979. See John Gillespie, Private Commercial Rights in Vietnam: A Comparative Analysis, 30 STAN. J. INT'L L. 325, 325 n.1 (1994); Max Spoor, State Finance in the Socialist Republic of Vietnam: The Difficult Transition from 'State Bureaucratic Finance' to 'Socialist Economic Accounting,' in POST-WAR VIETNAM: DILEMMAS IN SOCIALIST DEVELOPMENT 111 (David G. Marr \& Christine P. White eds., 1988).

584. See Christopher ENGHOLM, DOING Business IN THE NeW VIETNAM 20 (1995); James Taylor, Jr., Vietnam: The Current Legal Environment for U.S. Investors, 25 LAW \& POL'Y INT'L Bus. 469, 469 (1994).

585. George Irvin, Vietnam: Assessing the Achievements of Doi Moi, 31 J. DEv. STUD. 725, 744 (1995).

586. See Hoang K. Giao \& Hoang V. Cuong, Viemam's Private Economy in the Process of Renovation, in VIETNAM IN A CHANGING WORLD 151-52 (Irene Norlund et al. eds., 1995). 
benefited urban areas far more than rural areas, which by most accounts have experienced minimal improvement from marketization. ${ }^{587}$

Economic liberalization in Vietnam has revived the entrepreneurial presence of the predominantly urban Chinese minority. ${ }^{588}$ Today, the Chinese in Vietnam cluster in Ho Chi Minh City (still Saigon to most Vietnamese ${ }^{589}$ ), where they constitute about twelve percent of the population but control thirty to thirty-five percent of that city's commercial activity. ${ }^{590}$ For the moment, the Vietnamese government is openly encouraging the Chinese minority to play a substantial role in Vietnam's economic development, for example by engaging in joint ventures with the government and by bringing in foreign investment from their overseas contacts. $^{591}$

\section{Satisfaction of Model Conditions}

With the overwhelming majority of its population rural, undernourished, and chronically poor, Vietnam is a typical economically underdeveloped country, ${ }^{592}$ easily satisfying model condition one. Condition two (severe ethnic divisions) is probably met as well. Even assuming that the longstanding animosities between the northern Vietnamese and the southern Vietnamese do not reflect an ethnic conflict, deep divisions have long existed between the Vietnamese majority and the country's Cham, Chinese, Khmer, and highlander ethnic minorities. ${ }^{593}$ Moreover, consistent with condition four, the Vietnamese represent an impoverished majority with claims to being Vietnam's true indigenous "owners."

Whether the Vietnamese Chinese-who today constitute roughly three percent of the country's population ${ }^{594}$-represent a market-dominant

587. See, e.g., KAMM, supra note 144, at 264; Ari Kokko, Managing the Transition to Free Trade: Vietnamese Trade Policy for the 21st Century 4 (May 1997) (unpublished manuscript, on file with The Yale Law Joumal).

588. Even after the Communist takeover of the country and the mass departures after 1978, "a certain part of the business networks of the ethnic Chinese [in southern Vietnam] remained intact.... Furthermore, the trade links between the ethnic Chinese [who remained] in Vietnam and Chinese in Southeast Asia, especially Singapore, seem to have been functioning." AMER, supra note 296, at 56.

589. See David Lamb, Saigon by Any Name Lives on, L.A. Times, Sept. 23, 1997, at A1.

590. See Gale Eisenstodt, Caged Tiger, FORBES, Mar. 25, 1996, at 64.

591. See Vietnam Seeks Ethnic Chinese Potential for Development, JAPAN ECON. NEwSWIRE, Mar. 30, 1997, available in LEXIS, News Library, CURNWS File.

592. See KAMM, supra note 144, at 44, 228-29, 254-55, 268; Kokko, supra note 587, at 3 . Indeed, Vietnam "remains one of the world's poorest nations." KAMM, supra note 144, at 44 .

593. See Gerald CANNON HICKEY, FREE IN THE FOREST: ETHNOHISTORY OF THE VIETNAMESE CENTRAL HIGHLANDS 1954-1976, at 6, 60 (1982). This is true notwithstanding repeated (and largely unsuccessful) efforts by Vietnam to assimilate these groups. See id.

594. See WORLD ALMANAC AND BOOK OF FACTS, supra note 100, at 834 . 
minority in Vietnam (model condition three) is a crucial question, which will be discussed more fully below. For the moment, it will suffice to say that in urban Vietnam, where the Chinese are concentrated-and, significantly, where the vast part of Vietnam's recent growth has taken place ${ }^{595}$ - the Chinese appear to be prospering disproportionately as a result of economic liberalization vis-à-vis the Vietnamese majority. ${ }^{596}$

\section{Analysis}

Assuming for the moment that Vietnam satisfies all of the model conditions, one would not necessarily expect to see any of the model outcomes occurring in Vietnam because the government, while clearly marketizing under doi moi, has taken no steps toward democratization thus far. On the contrary, the recent ascension of General Le Kha Phieu to Vietnam's highest political post is widely viewed as a victory for old-guard Communists "more interested in preserving political control than in liberating economic energies." ${ }^{597}$ And while there is precedent in Vietnam's history for all three of the model outcomes, ${ }^{598}$ there are currently no signs of significant anti-Chinese backlash. Nevertheless, the model raises a set of previously unaddressed issues, with important policy implications for Vietnam, both now and in the event that it someday chooses to democratize.

\section{a. The Significance of the Vietnamese Chinese}

Without exception, the recent and increasingly voluminous law and development literature on Vietnam devotes little or no attention to the role of the Chinese minority in Vietnam. ${ }^{599}$ The same is true of the economics

595. See KAMM, supra note 144, at 61-65; Ron Corben, Two Cities Hope Their Synergies Will Propel Vietnam's Development, J. CoM., Oct. 15, 1997, at 13C; Lamb, supra note 589, at A1; Kokko, supra note 587, at 4.

596. See supra text accompanying notes 590-591; infra text accompanying notes 610-613.

597. An Untimely Retreat by Vietnam, N.Y. TIMES, Jan. 12, 1998, at A20; see David Lamb, Vietnam: Willful Contrarian in Booming Asia? Rise of New Communist Leader Seen as Step back for Already Lagging Nation, WASH. POST, Jan. 6, 1998, at A14. General Le Kha Phieu, who was designated Communist Party Secretary General in January 1998, was one of several new top officials recently named to replace the aging leadership of Do Muoi. The others are Prime Minister Phan Van Khai, an economist generally associated with market reform, and President Tran duc Luong, a mining engineer. See An Untimely Retreat by Vietnam, supra.

598. See supra text accompanying notes 554-555, 557-560 \& 571.

599. The vast bulk of this literature has been practitioner-oriented and "almost entirely descriptive." Sidel, supra note 57, at 713; see, e.g., ENGHOLM, supra note 584; ANNE C.M.J. SCHOT, LEGAL ASPECTS OF FOREIGN INVESTMENT IN THE SOCIALIST REPUBLIC OF VIETNAM (1996); VIETNAM: A LEGAL BRIEF (Frederick R. Burke \& David Howell eds., 1992); F. Gayle Connor, Vietnam: Trading With the Enemy or Investing in the Future?, 25 LAW \& POL'Y INT'L BuS. 481 (1994); Thao Cung \& Frank Meier, Overview of Recent Tax Reforms in Vietnam, 11 TAX Notes INT'L 1207 (1995); Glenn P. Jenkins \& Seth E. Terkper, Vietnam's Tax Reforms: Policies in Transition Economies, 6 TAX NOTES INT'L 469 (1993); Rory J. Radding \& H.T. Than, 
literature on Vietnam. ${ }^{600}$ This lack of attention is, at the very least, striking from an historical perspective. Even a cursory look at Vietnam's past reveals the deep anti-Chinese roots of Vietnamese nationalism. ${ }^{601}$ Although Vietnam's relation to China and the Hoa has always been complex, rejection of Chinese domination lies at the heart of Vietnam's most famous national legends and landmarks. ${ }^{602}$ More to the point, the Chinese in Vietnam, as elsewhere in Southeast Asia, played a pivotal role in Vietnam's economy for much of the country's recorded history. ${ }^{603}$

Nonetheless, the situation in Vietnam today is arguably different. As noted above, after 1975 the revolutionary Vietnamese government began confiscating Chinese wealth and subjecting the Chinese (along with their wealthy Vietnamese counterparts) to persecutions and purges. ${ }^{604}$ Although these actions were undertaken as part of a broader socialist upheaval in

Patent Protection in Vietnam: A Business Decision, 8 TRANSNAT'L LAW. 87 (1995); Taylor, supra note 584, at 469; Sesto E. Vecchi, Operating in Unstructured Legal Environments: The Vietnam Model, E. ASIAN EXEC. REP., July 1991, at 21; Paul B. Walsh, Vietnam's Labor Law: Can Labor Peacefully Coexist with Foreign Investment, Economic Development, and Structural Reform?, 8 TRANSNAT'L LAW. 125 (1995); Amo Wohlgemuth, The Law on Foreign Banking in Vietnam, 7 J. INT'L BANKING L. 284 (1992); Note, A Would-Be Tiger: Assessing Vietnam's Prospects for Gaining Most-Favored Nation Status from the United States, 38 WM. \& MARY L. REV. 1583 (1997); Note, Protection of Foreign Direct Investment in a New World Order: Vietnam: A Case Study, 107 HARV. L. REv. 1995 (1994). For unusually thoughtful or sophisticated treatments of Vietnam from a legal perspective, see NATALIE G. LICHTENSTEIN, A SURVEY OF VIET NAM'S LEGAL FRAMEWORK IN TRANSITION (World Bank Policy Research Working Paper No. 1291, 1994); Gillespie, supra note 583, at 325; Mark Sidel, The Re-emergence of Legal Discourse in Vietnam, 43 INT'L \& COMP. L.Q. 163 (1994); Pham van Thuyet, Legal Framework and Private Sector Development in Transitional Economies: The Case of Vietnam, 27 LAW \& POL'Y INT'L BUS. 541 (1996); and Mark Sidel, New Directions in the Study of Vietnamese Law, 17 MICH. J. INT'L L. 705 (1996) (reviewing LICHTENSTEIN, supra). For human rights work on Vietnam, see the sources cited in Sidel, The Re-emergence of Legal Discourse in Vietnam, supra, at 164 n.5.

600. See, e.g., World Bank, VIET Nam Financial SECTOR ReVIEW: AN AgENDa FOR FiNANCIAL SECTOR DEVELOPMENT 81 (1995) (Rep. No. 13135-VN); Kokko, supra note 587.

601. The anti-Chinese heritage of Vietnamese nationalism is often overlooked by Westerners, who perhaps tend to focus on the more recent events of the Vietnam War. See David K. Shipler, Robert McNamara and the Ghosts of Vietnam, N.Y. TIMES, Aug. 10, 1997, § 6 (Magazine), at 30. It is worth recalling that Vietnam was colonized by the Chinese for roughly a thousand years and by the French for roughly a hundred.

602. Thus, every Vietnamese knows that in 40 A.D., the Trung sisters led a brilliant, sweeping insurrection against China. Although the Han army eventually crushed the rebellion and captured the sisters,

Vietnamese legend has it that the heroic pair chose death at their own hands. To this day, the sisters who defied China remain the most honored national heroes or heroines. Even during the war between north and south, when the two Vietnams agreed on nothing, both Hanoi and Saigon, and all other towns on either side, named a principal street Hai Ba Trung, "two Trung sisters."

KAMM, supra note 144 , at 73 ; see also KARNOW, supra note 550, at 112 (stating that the Trung sisters, acclaimed by the Communists "as pioneer nationalists," are still venerated at temples throughout Vietnam).

603. See, e.g., AMER, supra note 296, at 11, 23; GolAY ET AL., supra note 95, at 395-96; KHANH, supra note 104, at 17-18, 44-53; GABRIEL KOLKO, VIETNAM: ANATOMY OF A PEACE 22 (1997); WU \& WU, supra note 296, at 83-86.

604. See AMER, supra note 296, at 35-36, 53-56; KHANH, supra note 104, at 81-82. 
which the Chinese were by no means the only victims, the result was a significant decline in the Vietnamese Chinese population. Between the early 1970s and the commencement of doi moi, the Chinese population in Vietnam fell by as much as half, ${ }^{605}$ and today there are virtually no Chinese in Vietnam's rural areas, where eighty percent of the population lives. ${ }^{606} \mathrm{~A}$ preliminary question, then, is whether the Chinese in Vietnam today represent a sufficient presence and are capable of exerting sufficient control over the country's economy to trigger the kind of ethnonationalist dynamics predicted by the model.

A negative answer cannot be inferred from the fact that the Chinese constitute only three percent of Vietnam's population. First, in countries like Indonesia and the Philippines (where the Chinese make up two to three percent of the population), their small numbers have not prevented the Chinese from being the repeated targets of resentment and state-directed retaliation. ${ }^{607}$ Second, although doi moi was initiated nearly a decade ago, the consensus is that Vietnam is still in the early stages of marketization; with the exception of the agricultural sector ${ }^{608}$ almost no privatization has taken place in Vietnam, and the state continues to occupy a "leading position in the multi-sector economy." ${ }^{609}$ If the Vietnamese government undertakes significant genuine market reforms, the economic role of the Vietnamese Chinese-who in the last decade have regained their prior prominence in Vietnam's light industry (and, to a lesser extent, banking and import-export) sectors, ${ }^{610}$ and who today include "a new breed of young ethnic Chinese who have made it big" ${ }^{611}$-will almost certainly increase. Already doi moi has brought an inflow of investments by Chinese from all over Southeast Asia "through their family connections in Cholon, Saigon's revitalized Chinatown." ${ }^{612}$ Moreover, increasing numbers of former Hoa-

605. See KHANH, supra note 104, at 23-25.

606. See Kokko, supra note 587 , at 4 .

607. See supra text accompanying notes 183-184, 265-266, 283, 301.

608. Collective agriculture was abolished in the late 1980s. The state share of agricultural production has fallen to less than three percent and is principally limited to "industrial crops such as coffee, tea and rubber." Kokko, supra note 587, at 4.

609. All Things Being Equal for the State, S. CHINA MORNING PosT, Sept. 17, 1997, at 6 (quoting Nguyen Tam Chien, Vietnam's Deputy Foreign Minister); see also Kokko, supra note 587 , at 7 .

610. See KHANH, supra note 104 , at 107. The Vietnamese Chinese have been particularly successful in "plastics, textiles and garments, shoes, and foodstuff-processing." Id. 17.

611. Harish Mehta, A New Phase for the Chinese Community, BuS. TIMES, Nov. 30, 1994, at

612. KAMM, supra note 144, at 61; see also KHANH, supra note 104, at 98. In 1994, ethnic Chinese from Hong Kong, Taiwan, and Singapore, who reportedly had "maintained key economic links with the Chinese community in Vietnam," accounted for roughly $40 \%$ of total foreign investment in Vietnam. See Mehta, supra note 611, at 17. 
many of whom have prospered in their new countries-are returning to Vietnam "to explore business opportunities." ${ }^{13}$

If the history of Southeast Asia is any guide, and if the great majority of Vietnamese continue in the near to midterm future to live in chronic poverty (as will very likely be the case even under the best of scenarios), then there is reason to worry that rising Chinese economic dominance will provide grist for anti-Chinese demagoguery and resurgent Vietnamese ethnonationalism. Recent journalistic accounts suggest that the revival of Chinese economic control throughout urban Vietnam has already produced "a simmering resentment among the Vietnamese," ${ }^{614}$ although the extent of such resentment is difficult to ascertain. Nevertheless, as the next few Sections will demonstrate, grounds for optimism may also exist.

\section{b. Political Favoritism, Corruption, and the Question of Market Dominance}

The economic dominance of the Chinese in Southeast Asia has not always stemmed purely from their market prowess. In Vietnam, as elsewhere in the region, Chinese economic success often has reflected superior political connections as much as superior entrepreneurialism. ${ }^{615}$ This was certainly true during the Nguyen dynasty, when the Hoa enjoyed preferential economic treatment from the state. ${ }^{616}$ More egregiously, Chinese economic power during the Saigon regime clearly reflected in part nonmarket factors. After Nguyen Van Thieu seized power in Saigon in 1966, " a small coterie of Chinese worked with him to play the leading role in exploiting South Vietnam corruptly." ${ }^{617}$ After Saigon fell, Thieu fled Vietnam with millions of dollars in gold, ${ }^{618}$ while his Chinese cronies, "who had been exporting large amounts of capital well before 1975," drew on "their personal connections in Southeast Asia ... to go into exile and prosper elsewhere." 619

Accordingly, while the Chinese in Vietnam often have been targets of state discrimination, ${ }^{620}$ an argument nevertheless can be made that their historical economic dominance to some extent reflects political favoritism. To be sure, such favoritism raises the further question of why those in

613. KHANH, supra note 104 , at 98 .

614. Mehta, supra note 611 , at 17; see also Eisenstodt, supra note 590, at 64 .

615. See supra note 148 and accompanying text. Although ethnic generalizations are always potentially suspect, it is striking that the Vietnamese are themselves widely regarded as an entrepreneurial people, culturally "industrious and inventive." KAMM, supra note 144, at 24.

616. See supra text accompanying notes 556-558.

617. KoLKO, supra note 603 , at 22 .

618. See KARNOW, supra note 550, at 456.

619. KOLKO, supra note 603 , at 22.

620. See, e.g., AMER, supra note 296, at 10, 19-20 (describing various anti-Chinese economic restrictions). 
power chose to favor (and to "deal" with) the Chinese. Part of the answer must be that the Chinese in Vietnam, as elsewhere in Southeast Asia, had already established themselves as a successful, wealth-generating "middleman" minority. ${ }^{621}$ Still, if part of the Hoa's historical economic success owes not to market forces but to political favoritism, then genuine marketization (at least in theory) might eliminate this favoritism and ameliorate the historical ethnoeconomic imbalance.

\section{c. The Possibility of Vietnamese Exceptionalism}

Another possible ground for optimism lies in the fact that Vietnam is considerably more Sinicized than other Southeast Asian nations. ${ }^{622}$ For over two millennia, Vietnam's history and culture have been closely intertwined with those of its colonizer-neighbor. ${ }^{623}$ The results are visible throughout Vietnamese society, from its embrace of Confucianism and Taoism to its literature, art, and architecture-much more so than in Indonesia, Malaysia, or the Philippines. ${ }^{624}$ Additionally, there has been considerable "blood admixture" between the Vietnamese and the Chinese. ${ }^{625}$ As a result, at least arguably, Vietnam may be less prone to anti-Chinese animus and politicking.

In other words, the hope would be that Vietnam will prove exceptional in Southeast Asia in its greater potential tolerance of Chinese economic success. Unfortunately, this hope flies somewhat in the face of historical fact. ${ }^{626}$ Moreover, even if relations between the Vietnamese and the Hoa are relatively benign for the moment, ethnic relations are highly malleable, and,

621. See KHANH, supra note 104, at 57.

622. See AMER, supra note 296, at 7-8; KAMM, supra note 144, at 128.

623. See AMER, supra note 296, at 2,7.

624. See id. at 7; KAMM, supra note 144, at 128-29; see also KEITH WELLER TAYLOR, THE BIRTH OF VIETNAM 80-81, 281 (1983) (noting the Chinese roots of Buddhism, Buddhist architecture, and Taoism in Vietnam). Prominent Vietnamese have described Vietnam as part of the "chopstick civilization," referring to

the four nations that are linked by much deeper cultural ties than their use of Chinese eating utensils-China itself, Japan, Korea, and Vietnam. The motherland of Chinese culture and its three offspring, with all their differences, form a cultural family quite distinct from the rest of Asia. Vietnam is its southernmost member.

TAYLOR, supra, at 128. A central aspect of Vietnam's Chinese heritage is its adherence to the strong Confucian culture that places the world "under an established order, with a revered godlike figure at the top and center of a highly centralized ... hierarchy devoted to its service." Id.

625. PURCELL, supra note 266, at 201; see also id. at 179, 200-02 (detailing the "inextricably commingled" blood of the Chinese and the Annamites). Particularly in North Vietnam, the Chinese were assimilated early on and regarded as Vietnamese nationals. See AMER, supra note 296 , at 8 . More generally, after 1829 , children of mixed marriages between the Chinese and the Vietnamese were considered Vietnamese. See id. at 8-9. In addition, during the Saigon regime, many foreign born Chinese eventually became Vietnamese nationals for economic reasons. See id. at 22,24 .

626. See, e.g., PURCELL, supra note 266, at 202-03 (detailing deep, historical anti-Chinese animus in Indochina). 
as one observer of Vietnam's relation to China put it in 1965, it would be an error to "attribute more than is justified to their common cultural heritage." 627

\section{Directions}

Today's legal commentary on Vietnam is almost unanimous in encouraging this potential "Asian Tiger" to privatize its debt-ridden state sector and to normalize its trade and investment regime as quickly as politically feasible. ${ }^{62}$ As usual, this largely practitioner-oriented literature has very little to say about distributional problems, much less ethnodistributional problems. By contrast, this Article has argued that, if markets and eventually democracy are the ultimate goals in Vietnam, then distributional issues must be addressed.

As a general matter, it will be important for Vietnam's policymakers to try to find ways to spread the benefits of marketization beyond the (Chinese-dominated) urban areas to the country's immiserated rural areas. ${ }^{629}$ Along these lines, in the context of privatization, I have elsewhere suggested strategies that marketizing governments might adopt to create broader distribution of market-generated wealth. ${ }^{630}$ Although careful tailoring to Vietnam's particular circumstances would be necessary, such strategies might include ownership restrictions; rate, service, and product regulations; and environmental quality regulations. ${ }^{631}$ In addition, statebuilding initiatives, typically sponsored by international financial or development organizations and directed at establishing "functioning and accountable bureaucracies capable of enforcing the regulatory frameworks essential to the distribution of [the market's] benefits," ${ }^{632}$ will be essential to Vietnam's development.

More specifically, marketization in Vietnam will have to deal with the complex position occupied by the Hoa. Assuming that the Chinese prove to be market-dominant in Vietnam (as they seem to be throughout Southeast Asia), the crucial question is whether this market dominance will trigger the kind of ethnonationalist dynamic predicted by the model.

On the exceptionalist view, it will not. If Vietnam's relation to its Chinese minority really is an exception to the rule that has prevailed

627. Id. at 201.

628. See, e.g., Gillespie, supra note 583, at 373-77; Jenkins \& Terkper, supra note 599, at 480; Taylor, supra note 584, at 470-78; Wohlgemuth, supra note 599, at 284, 290-91; Vecchi, supra note 599, at 23; Kokko, supra note 587, at 53-58.

629. Cf. Kokko, supra note 587, at 4 (indicating that the market's benefits have been unequally distributed in Vietnam).

630. See Chua, supra note 18, at 288-98.

631. See id.

632. Id. at 299-300. 
virtually everywhere else in Southeast Asia, then the pursuit of full-blown marketization (coupled with after-market social welfare programs) could be the best strategy for Vietnam. On this theory, the economic success of the Vietnamese Chinese should be actively encouraged and their entrepreneurial skills and experience harnessed to help fuel Vietnam's development. Moreover, to the extent that Vietnam establishes itself as an attractive investment site for global Chinese capital, the country stands to gain enormously.

This strategy, however, raises certain risks, which will have to be carefully monitored. To begin with, corruption in Vietnam today is chronic and pervasive-Vietnam has been ranked "as one of Asia's three most corrupt nations." ${ }^{633}$ It is often hoped that marketization will ameliorate corruption in developing countries: "In general, any reform that increases the competitiveness of the economy will reduce incentives for corrupt behavior." ${ }^{634}$ Unfortunately, the last decade has taught us that one of the most intractable problems of marketization in the developing world is corruption within the marketization process itself. ${ }^{635}$ In Vietnam, this danger could be particularly acute if the government pursues excessively pro-Chinese policies under the guise of marketization. Parasitic self-dealing arrangements between the Vietnamese ruling elite and Chinese business interests have a long history ${ }^{636}$-as do popular reactions against the "greedy" and "unscrupulous" Chinese. ${ }^{637}$

Even if there is more tolerance of Chinese economic success in Vietnam than there has been elsewhere in Southeast Asia, this tolerance will not be unlimited. To the extent that Vietnam seeks to harness Chinese economic energy and investment capital, every effort should be made to ensure that wealthy Chinese, inside and outside of Vietnam, make significant, visible contributions to local (and especially rural) Vietnamese communities. Such contributions could take the form of infrastructural improvements, housing, hospitals, schools, and so on.

More fundamentally, there is the risk that the exceptionalist view will prove to be a mirage. As detailed above, there is not only historical precedent for anti-Chinese movements in Vietnam but also some evidence of current anti-Chinese ethnoeconomic resentment. ${ }^{638}$ Accordingly, there remains a substantial possibility that markets and democracy in Vietnam,

633. KolKo, supra note 603 , at 76 .

634. Susan Rose-Ackerman, Corruption and Development, in ANNUAL WORLD BANK CONFERENCE ON DEVELOPMENT ECONOMICS 1997, at 35, 46 (Boris Pleskovic \& Joseph E. Stiglitz eds., 1998); see also Domingo F. Cavallo, Lessons from Argentina's Privatization Experience, 50 J. INT'L AFF. 459, 462,474 (1997).

635. See Rose-Ackerman, supra note 634, at 46.

636. See supra text accompanying notes 557-558, 617-619.

637. PURCELL, supra note 266, at 203; supra text accompanying notes 554-555, 576-582.

638. See supra text accompanying notes 554-555 \& 614 . 
coupled with disproportionate Chinese economic success, will trigger the destructive dynamic predicted by the model.

In these circumstances, the Vietnamese government should be discouraged from pursuing a Suharto-style strategy of preferential treatment for the Hoa. ${ }^{639}$ On the contrary, market preferences favoring the ethnic Vietnamese might be far more prudent. Along these lines, the Vietnamese government already has in recent years taken steps favoring overseas Vietnamese (as compared to other potential foreign investors), who are increasingly returning to, and investing in, Vietnam. ${ }^{640}$ Although such favoritism raises concerns of ethnic discrimination, especially from the point of view of the developed world, it may be justified and sensible for a country with Vietnam's history.

As recent events in Bosnia starkly illustrate, ethnic relations even among relatively well-integrated groups are very unstable. In Vietnam, the prospects for free-market democracy will turn on the choices of political elites and on the tolerance of the Vietnamese for a resurgently successful Hoa community. Vietnam's history offers precedents for the full range of reactions, from accommodationism to eliminationism. Unfortunately, the degree of ethnic intolerance in Vietnam is difficult-perhaps even impossible-to determine in advance. Of all the mines still buried in Vietnam, this one may pose the greatest threat to the nation's future development.

\section{CONCLUSION}

History never repeats itself exactly. Ethnic relations are volatile and malleable - for better or worse-and there is certainly room to hope for market miracles. Whether such a hope should form the basis of law and development policymaking, however, is another matter. The work of Western lawyers and legal academics in the developing world todayprofound and transformative though it has been-has proceeded in blissful and almost willful ignorance of three crucial facts. The first concerns the relationship between markets and ethnicity; the second, the relationship between markets and democracy; and the third, the interplay among all three of these forces.

639. See supra text accompanying notes 312-317.

640. See David Lamb, Viet Kieu: A Bridge Between Two Worlds, L.A. TIMES, Nov. 4, 1997, at A1; Vietnam New Preferential Treatment for Viet Kieu Likely, SAIGON TIMES DAILY, Jan. 16, 1998, available in LEXIS, News Library, SGNDLY File; Vietnam Offers Visiting Overseas Viemamese Discounts, AGENCE FR.-PRESSE, Sept. 23, 1997, available in LEXIS, News Library, AFP File. Overseas Vietnamese have at their disposal an estimated $\$ 20$ billion, roughly one-fourth of Vietnam's gross domestic product. See CIA, THE WORLD FACTBOOK 1995, at 454 (1995) (listing Vietnam's 1994 gross domestic product as $\$ 83.5$ billion); Lamb, supra, at A1. 
First, the idea that the invisible hand of the market will benefit some people over others is hardly new. Proponents of laissez-faire capitalism respect and relish the anonymous justice of the market insofar as it promises to reward anyone who is sufficiently entrepreneurial, hardworking, and lucky. ${ }^{641}$ In Part III, however, I demonstrated that markets tend to benefit not just some people over others, but also some ethnic groups over others in virtually every part of the world. In the developing world, moreover, markets often favor certain ethnic minorities over the rest of the population. This phenomenon in the developing world is potentially very destabilizing, yet it is almost uniformly disregarded by lawyers and scholars involved in marketization.

Second, in the developing world, the ethnic groups favored by the market are frequently different from the ethnic groups favored by majority rule. As a result, markets and democracy in the developing world are not always mutually reinforcing. On the contrary, they are constantly colliding, sometimes to good effect, but at other times, catalytically and catastrophically. What this means for marketizing and democratizing lawyers is that, like it or not, the work they do in the developing worldwhether it is privatization, project finance, or constitutional advising-has implications for ethnic conflict. It also means that many Western policy suggestions may be dangerously myopic.

The final misperception concerns the relationship among markets, democracy, and ethnicity. Prevailing law and development orthodoxy assumes that marketization and democratization-the current prescription for economic and political underdevelopment-will cure ethnic conflict too. By contrast, this Article insists that marketization and democratization - to the extent that they are successful-may, in countries such as South Africa, Kazakhstan, and Vietnam, and throughout the developing world, catalyze ethnic tensions in a highly determinate and predictable fashion. The market will not lift the great majority of citizens out of poverty. Rather, it will aggravate, at least in appearance and probably in reality, the existing ethnic maldistribution of wealth. Democracy will not make all voters imagine themselves as coparticipants in a fraternal national community. Rather, the competition for votes will more likely foster the emergence of ethnic political entrepreneurs (particularly among the impoverished majority) and active ethnonationalist movements. Markets and democracy cannot be regarded unproblematically as solutions to the dangers of ethnic strife in deeply divided societies. Particularly given the unprecedented international influence of American lawyers today,

641. See, e.g., MILTON FRIEDMAN, CAPITAlISM AND FREEDOM 162-64 (1982); 2 F.A. HAYEK, LAW, LEGISLATION AND LIBERTY: THE MIRAGE OF SOCIAL JUSTICE 6S-69 (1976); ROBERT NOZICK, ANARCHY, STATE AND UTOPIA 228-29 (1974). 
marketizing and democratizing lawyers who continue to ignore the developing world's historic distributional problems, especially its ethnodistributional problems, are engaging in "romanticism or worse." 642

642. GEERTZ, supra note 95 , at 156 (referring to the blind faith in the ability of laissez-faire to achieve sustainable growth in developing countries as "romanticism or worse"). 
HeinOnline -- 108 Yale L.J. 108 1998-1999 


\title{
Litigating Whiteness: Trials of Racial Determination in the Nineteenth-Century South
}

\author{
Ariela J. Gross ${ }^{\dagger}$
}

\author{
CONTENTS
}

I. INTRODUCTION

II. ThE SHIFTING ESSENCES of RACE IN THE NINETEENTH-CENTURY

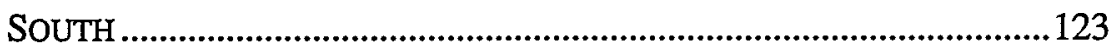

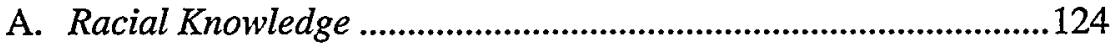

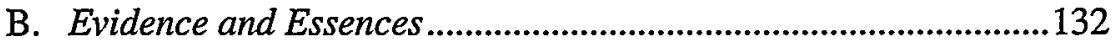

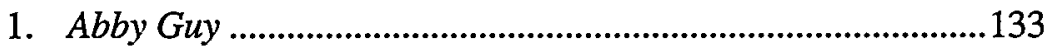

2. Race as Physical Marker ...................................................137

3. Race as Documented Ancestry..............................................141

4. Race as Ascriptive Identity: Reputation, Associations, and Reception in Society...........................................................147

5. The Rise of Race as Science and Performance ......................151

III. PERFORMING WHITENESS

$\dagger$ Associate Professor of Law, University of Southern California. I am indebted to Scott Altman, Jody Armour, Jacob Cogan, David Cruz, Mary Dudziak, Karen Dunn-Haley, Laura Edwards, Harry Elam, George Fredrickson, Ron Garet, Jon Goldman, Bob Gordon, Tom Green, Janet Halley, Leslie Harris, Hendrik Hartog, Greg Keating, Bill Nelson, Peggy Pascoe, Rick Pildes, Renee Romano, Mike Shapiro, Larry Simon, Dave Slawson, Nomi Stolzenberg, Eric Talley, Chris Waldrep, Wendy Wall, Ted White, and participants of the NYU Legal History Colloquium and of faculty colloquia at USC, UCLA, and Rutgers-Newark Law Schools for reading and commenting on drafts of this Article. Discussions at the Center for Feminist Research and the Faculty Women's Writing Group at USC helped to clarify my thinking. Peggy Pascoe generously provided the list of cases that began this research, and Anthony Kaye guided me to new sources. The archival research for this Article was generously supported by the USC Law School and the Zumberge Research and Innovation Fund at USC. Many librarians and archivists made this work possible; I thank in particular Charles Miller, Laura Cadra, and Corrin Gee of the USC Law Library; Charles Sherrill of the Tennessee State Archives; Norwood Kerr of the Alabama Department of Archives and History; Marie Windell of the Earl K. Long Library at the University of New Orleans; Nicky Sherman of the Pulaski County, Arkansas Law Library; Ann Webster of the Mississippi Department of Archives and History; and Mark Stone of the Kentucky State Archives. Bill D'Angelo, Sonya Springer, Karin Lewicki, Debra Mayfield, and Rebecca Wolff provided valuable research assistance. 